\title{
Implications of the mitochondrial interactome of mammalian thioredoxin 2 for normal cellular function and disease
}

Christos T. Chasapis ${ }^{1}$, Manousos Makridakis ${ }^{2}$, Anastassios E. Damdimopoulos ${ }^{3}$, Jerome Zoidakis $^{2}$, Vassiliki Lygirou ${ }^{2}$, Manolis Mavroidis ${ }^{2}$, Antonia Vlahou ${ }^{2}$, Antonio MirandaVizuete $^{4}$, Giannis Spyrou ${ }^{5}$, Alexios Vlamis-Gardikas ${ }^{6 *}$

${ }^{1}$ Institute of Chemical Engineering Sciences (ICE-HT), Foundation for Research and Technology, Hellas (FORTH), Platani 26504, Greece

${ }^{2}$ Biomedical Research Foundation, Academy of Athens (BRFAA), Athens, Greece

${ }^{3}$ Department of Biosciences and Nutrition, Center for Innovative Medicine (CIMED), Karolinska Institutet, Huddinge, Sweden

${ }^{4}$ Redox Homeostasis Group, Instituto de Biomedicina de Sevilla (IBIS), Hospital Universitario Virgen del Rocío/CSIC/Universidad de Sevilla, 41013 Sevilla, Spain

${ }^{5}$ Department of Clinical and Experimental Medicine, Division of Clinical Chemistry, Linköping University, S-581 85 Linköping, Sweden

${ }^{6}$ Department of Chemistry, University of Patras, Rion 26504, Greece

*Corresponding author. Email: avlamis@upatras.gr

Running title: The thioredoxin 2 interactome 


\begin{abstract}
Multiple thioredoxin isoforms exist in all living cells. To explore the possible functions of mammalian mitochondrial thioredoxin 2 (Trx2), an interactome of mouse Trx 2 was initially created using (i) a monothiol mouse Trx 2 species for capturing protein partners from different organs and (ii) yeast two hybrid screens on human liver and rat brain cDNA libraries. The resulting interactome consisted of 195 proteins (Trx2 included) plus the mitochondrial 16S RNA. 48 of these proteins were classified as mitochondrial (MitoCarta2.0 human inventory). In a second step, the mouse interactome was combined with the current four-membered mitochondrial sub-network of human Trx2 (BioGRID) to give a 53-membered human Trx2 mitochondrial interactome (52 interactor proteins plus the mitochondrial 16S RNA). Although thioredoxins are thiol-employing disulfide oxidoreductases, approximately half of the detected interactions were not due to covalent disulfide bonds. This finding reinstates the extended role of thioredoxins as moderators of protein function by specific non-covalent, protein-protein interactions. Analysis of the mitochondrial interactome suggested that human Trx2 was involved potentially in mitochondrial integrity, formation of iron sulfur clusters, detoxification of aldehydes, mitoribosome assembly and protein synthesis, protein folding, ADP ribosylation, amino acid and lipid metabolism, glycolysis, the TCA cycle and the electron transport chain. The oxidoreductase functions of $\operatorname{Trx} 2$ were verified by its detected interactions with mitochondrial peroxiredoxins and methionine sulfoxide reductase. Parkinson's disease, triosephosphate isomerase deficiency, combined oxidative phosphorylation deficiency, and lactate dehydrogenase b deficiency are some of the diseases where the proposed mitochondrial network of Trx 2 may be implicated.
\end{abstract}

Key words: redox, disulfide, interactome, interactor, thiol-disulfide interchange, thioredoxin, mitochondrion

\begin{abstract}
Abbreviations
2D: two dimensional; NADPH: reduced nicotinamide adenine dinucleotide phosphate; Trx: thioredoxin; TrxR: thioredoxin reductase; Y2H: yeast two hybrid.
\end{abstract}




\section{Introduction}

Thioredoxin and glutaredoxin are proteins that maintain the reduction of cytosolic disulfides in most living cells and are implicated in many different functions [1]. Their first discovered pivotal role was their ability to donate electrons to ribonucleotide reductases for the reduction of ribonucleotides to deoxyribonucleotides, the precursors of DNA synthesis [2, 3]. While reducing substrates, thioredoxins and glutaredoxins get oxidized to be in turn reduced by thioredoxin reductase (TrxR) and glutathione respectively. The ultimate electron donor for these systems is NADPH. Their ability to donate electrons places thioredoxins and glutaredoxins in the general category of 'antioxidants' whose specific functions are determined by the particular molecule that receives their electrons. Reduction of methionine sulfoxide reductase by thioredoxins and glutaredoxins is a well known example of such antioxidant function $[4,5]$. Thioredoxins and glutaredoxins may have common substrates with the reduction of glutathione mixed disulfides being exclusive for glutaredoxins [6]. In some cases, thioredoxins (and glutaredoxins) may bind non-covalently to other proteins for gain/loss of function. In the case of Escherichia coli (E. coli), binding of reduced thioredoxin 1 (EcoTrx1) to gene 5 protein of phage T7 gives rise to a functional T7 DNA polymerase [7]. Reduced cytosolic human thioredoxin 1 (Trx1) may bind to apoptosis signaling kinase 1 (ASK1) to keep the kinase inactive. Removal of Trx1 from ASK1 by oxidation of Trx1 or by the thioredoxin-interacting protein (Txnip) promotes apoptosis ([8] and references therein). Reduced mitochondrial thioredoxin 2 (Trx2) will also normally bind to mitochondrial ASK1 and prevent its activation and concomitant apoptosis [9, 10]. Therefore, thioredoxins (and glutaredoxins) may associate with a number of proteins that constitute their interactomes and affect their functions decisively. The thioredoxin and glutaredoxin interactomes, however, are far from complete.

Mammalian cells have two distinct thioredoxin types; one cytosolic (Trx1) and one mitochondrial ( $\operatorname{Trx} 2)$, each protein being reduced by its specific $\operatorname{Trx} R$. Trx 1 is reduced by cytosolic TrxR isoforms [11], whereas Trx2 is reduced by a mitochondrial TrxR (thioredoxin reductase 2 or TrxR2) [12]. Although Trx1 is the prominent thioredoxin species in most tissues, it is barely detectable in heart and skeletal muscle where Trx 2 is highly expressed [13]. Trx 1 and Trx 2 may respond differently to external stimuli affecting the redox state of the cell. In the case of increased reactive oxygen species (ROS) via epidermal growth factor addition, selective oxidation of cytoplasmic Trx 1 but not Trx 2 or the glutathione pools [14] 
occurred. On the other hand, tumor necrosis factor $\alpha(\mathrm{TNF} \alpha)$ caused preferential oxidation of Trx2 whose overexpression inhibited the TNF $\alpha$-induced, NF- $\kappa \mathrm{B}$ translocation to the nucleus (activation) [15]. Overexpresion of Trx 1 or Trx 2 may have opposing effets: in the regulation of transcription of hypoxia-inducible factor-1 $\alpha$ (Hif-1 $\alpha)$ [16], Trx 2 overexpression in HEK cells lowered Hif-1 $\alpha$ protein levels, whereas Trx 1 raised them. Since the mRNA levels of Hif$1 \alpha$ were unaltered, results were explained in view of the activation of transcription factors that regulated cap-dependent translation and by the production of ROS. Overexpression of Trx2 increased the production of mitochondrial ROS and decreased translation of Hif-1 $\alpha$ [16].

Thioredoxins (and dithiol glutaredoxins) have an active site composed of two vicinal thiols $(\mathrm{CxxC})$ that is reversibly oxidized/reduced during the catalytic cycle of the enzyme. The electron transfer of the thioredoxin thiols to the substrate disulfide starts with a nucleophilic attack from the thiolate of the N-terminal thiol (catalytic) of reduced thioredoxin. A following attack from the second non-catalytic, resolving thiol to the sulfur of the catalytic that participates in the temporary disulfide with the substrate leads to an oxidized thioredoxin and a reduced substrate. This mechanism has been employed to trap thioredoxin-substrates by using mutant monothiol thioredoxins with the second "resolving" thiol of the active site being changed to Ser (mutant active site: $\mathrm{CxxS}$ ). The mutated monothiol thioredoxins can attack and bind to their dithiol substrates but cannot be released from them as they lack the second noncatalytic cysteine. Monothiol thioredoxin mutants of EcoTrx1 [17, 18], plant thioredoxins [19], Plasmodium falciparum [20] and Entamoeba histolytica [21] have been used (among others) to identify their potential substrates. Monothiol mutant glutaredoxins have served the same purpose (e.g. monothiol human glutaredoxin 2 [22]).

Monothiol mouse Trx 1 has been used in combination with isotope-coded affinity tags to identify transnitrosylation targets [23] and protein networks [24], while expression of monothiol Trx1 in whole mice has provided the interacting proteome of cytosolic Trx1 [25]. The current experiment-based interactome of human Trx 1 is composed of 147 proteins [26] compared to the 59 interactors described for Trx2 [26], with only four of the latter being mitochondrial (MitoCarta [27]). Respective interactomes for the rat and mouse Trx2 are currently not available ([26]). To create an interactome for mouse Trx2, we employed an immobilized monothiol mouse Trx2 lacking its mitochondrial signal sequence, for the detection of strong non-covalent and covalent (disulfides) interactions with proteins from different mouse tissues. In addition, yeast two hybrid $(\mathrm{Y} 2 \mathrm{H})$ screens with rat and human cDNA libraries were used to identify weaker non-covalent interactions. The novel results (194 proteins plus the mitochondrial 16S RNA) were integrated with the described 59 interactors 
(BioGRID) of human Trx2 to give an updated human interactome of 253 proteins (excluding Trx2). 52 of these proteins were mitochondrial (four from BioGRID, plus 48 novel hits), while the mitochondrial 16S RNA was identified as an additional interactor by Y2H screens. The possible novel cellular functions of Trx 2 and its association with human diseases are discussed within the context of its mitochondrial interactome. 


\section{Materials and Methods}

\section{Construction of plasmid for the overexpression of $\Delta \operatorname{Trx} 2 \mathrm{C} 93 \mathrm{~S}$.}

A plasmid (pET15b) containing the gene encoding mouse Trx2 [13] was used as a template to initially generate the 5' and 3; parts of the TXN2 gene, each coding for the C93S mutation and containing some common sequence. The 5' part was amplified with primers F-NdeI (CGA GGA TCC ATA TGA CAA CCT TTA ATA TCC AGG) and C93S-RC (CAG GAT CTT GCT GGG TCC ACA CC) as forward and reverse complementary respectively, while the 3' part was amplified using F-C93S (GGT GTG GAC CCA GCA AGA TCC TG) and EcoRIRC (CCC TTA GAA TTC CCA ATC AGC TTC TTC AGG) as forward and reverse complementary respectively. The 5' and 3' PCR fragments of the gene containing the C93S mutation were gel-purified, mixed and used as a template for the F-NdeI and EcoRI-RC primers to receive a PCR product encoding Trx2 without its 1-59 mitochondrial targeting signal (now starting as (M)TTF...) and bearing the C93S mutation ( $\triangle \mathrm{Trx} 2 \mathrm{C} 93 \mathrm{~S})$. Insertion of the product in the NdeI and EcoRI of vector pET24a+ gave rise to plasmid pET24a $+\Delta \operatorname{Tr} x 2 \mathrm{C} 93 \mathrm{~S}$ coding for $\Delta \operatorname{Tr} x 2 \mathrm{C} 93 \mathrm{~S}$ comprised of 107 amino acids. The mouse $\operatorname{Tr} 2$ lacking its mitochondrial targeting sequence is identical to the enzyme from rat and differs in only two amino acids from human Trx2.

\section{Purification of $\Delta \operatorname{Trx} 2 \mathrm{C} 93 \mathrm{~S}$}

E. coli BL21(DE3) cells were transformed with plasmid pET24a+4Trx2C93S and were grown in LB medium with kanamycin $(50 \mathrm{mg} / \mathrm{ml})$, in 11 cultures in 21 flasks at $37^{\circ} \mathrm{C}, 140$ rpm. At $\mathrm{A}_{600}$ of $\sim 0.5$, IPTG was added $(0.5 \mathrm{mM})$, temperature was set to $25^{\circ} \mathrm{C}$ and cells were further grown for 6 hours after which they were harvested and resuspended in $20 \mathrm{mM}$ Tris (non-buffered) as $100 \mathrm{~A}_{600} / \mathrm{ml}$. EDTA $(1 \mathrm{mM})$, lysozyme $(0.1 \mathrm{mg} / \mathrm{ml})$ and 2 mercaptoethanol $(50 \mathrm{mM})$ were added and the resuspension was frozen and thawed for three times. The sample was sonicated thoroughly and centrifuged at 10,000 g for $30 \mathrm{~min}$. The occurring total lysate supernatant (TCLS) was filtered through a $2 \mu \mathrm{m}$ filter and loaded on a DEAE FF column equilibrated with $20 \mathrm{mM}$ Bis-Tris- $\mathrm{HCl}, \mathrm{pH}$ 6.7. $\Delta \mathrm{Trx} 2 \mathrm{C} 93 \mathrm{~S}$ was eluted in a 0 to $1 \mathrm{M} \mathrm{NaCl}$ gradient at $\sim 15 \mathrm{mS} / \mathrm{cm}$ (supplementary figures 2 and 3). Fractions containing $\Delta \operatorname{Trx} 2 \mathrm{C} 93 \mathrm{~S}$ (by SDS-PAGE) were concentrated, made up to $5 \mathrm{mM}$ DTT, stood for $30 \mathrm{~min}$ at RT and chromatographed on Sephadex G-50 Superfine in $20 \mathrm{mM}$ Hepes-KOH, $1 \mathrm{mM}$ EDTA, 100 $\mathrm{mM} \mathrm{NaCl}, \mathrm{pH} 7.0$, at $0.1 \mathrm{ml} / \mathrm{min}$. $\Delta \mathrm{Trx} 2 \mathrm{C} 93 \mathrm{~S}$ was obtained in a homogeneous stage after this 
purification step. The extinction coefficient $\varepsilon_{280}$ of purified $\Delta \operatorname{Trx} 2 \mathrm{C} 93 \mathrm{~S}$ was assumed as $6990 \cdot \mathrm{M}^{-1} \cdot \mathrm{cm}^{-1}$ (https://web.expasy.org/protparam/).

\section{Immobilization of $\Delta \mathrm{Trx} 2 \mathrm{C} 93 \mathrm{~S}$ on solid phase}

Homogeneous $\Delta \operatorname{Trx} 2 \mathrm{C} 93 \mathrm{~S}$ (estimated $\mathrm{pI}$ of 4.9) was coupled to Affi-Gel 15 according to the protocol of the manufacturer (Bio-Rad). In experiments concerning interaction of $\Delta \operatorname{Trx} 2 \mathrm{C} 93 \mathrm{~S}$ with crude lysates, $\sim 10 \mathrm{mg} \Delta \mathrm{Tr} 2 \mathrm{C} 93 \mathrm{~S}$ was immobilized/ml of Affi-Gel beads. When mitochondrial extracts were obtained, $1 \mathrm{ml}$ of beads contained $\sim 1 \mathrm{mg} \Delta \operatorname{Tr} 2 \mathrm{C} 93 \mathrm{~S}$. The conjugated beads were used for a maximum of two affinity experiments after which they were discarded.

\section{Preparation of tissue extracts}

Male mice of C57BL/6 genetic background, 5-6 months old, were used. The procedures for the care and treatment of animals were approved by the Animal Care Committee of East Attica County, Athens, Greece, and followed the guidelines of the Association for the Assessment and Accreditation of Laboratory Animal Care and the recommendations of the Federation of European Laboratory Animal Science Association.

Lung, kidney and skeletal muscle were isolated immediately after sacrifice, inserted in liquid $\mathrm{N}_{2}$ and stored at $-80{ }^{\circ} \mathrm{C}$. Frozen tissue was initially crushed and homogenized by pestle in a liquid $\mathrm{N}_{2}$ cooled mortar to a fine powder which was transferred to ice cold $50 \mathrm{mM}$ Tris-HCl, 1 mM EDTA, $0.2 \mathrm{M} \mathrm{KCl}, \mathrm{pH} 8.0$ with a freshly added cocktail of protease inhibitors $(1 \mathrm{mM}$ PMSF, $0.5 \mathrm{mM} \mathrm{Na} \mathrm{VO}_{4}, 5 \mathrm{mM} \mathrm{NaF}, 1: 25 \mathrm{v} / \mathrm{v}$ complete (EDTA free) protease inhibitor cocktail in PBS from Roche (catalogue number: 11873580001). The sample was sonicated on ice thoroughly. Triton X-100 $(1 \% \mathrm{v} / \mathrm{v})$ was added and the homogenate was centrifuged at $14.000 \mathrm{~g}$ for $45 \mathrm{~min}$ to obtain the total cell lysate supernatant (TCLS) fraction. In the case of kidney lysate preparations for example, to $0.647 \mathrm{gr}$ of pulverized kidney tissue, $5 \mathrm{ml}$ of 50 $\mathrm{mM}$ Tris-HCl, $1 \mathrm{mM}$ EDTA, $0.2 \mathrm{M} \mathrm{KCl}, \mathrm{pH} 8.0$ were added. Typical protein concentrations of the TCLS were in the order of $\sim 10 \mathrm{mg} / \mathrm{ml}$.

\section{Preparation of mitochondrial extracts}

Heart and brain (and skeletal muscle in one case: supplementary table 1.13) mitochondrial fractions were prepared according to [28]. In more detail, animals were perfused with ice-cold PBS, and hearts and quadriceps muscle were isolated from six mice. Freshly isolated tissue (1-2 gr muscle/heart, or seven whole brains without their cerebella) was minced in $10 \mathrm{ml}$ ice- 
cold MSE (225 mM mannitol, $75 \mathrm{mM}$ sucrose, $1 \mathrm{mM}$ EGTA, $1 \mathrm{mM}$ Tris- $\mathrm{HCl} \mathrm{pH}$ 8.0, 0.5 $\mathrm{mM} \mathrm{Na}_{3} \mathrm{VO}_{4}, 5 \mathrm{mM} \mathrm{NaF}, 1 \mathrm{mM}$ PMSF and and protease inhibitors (Sigma Protease Inhibitor Cocktail P8340). The minced tissue was further homogenized by up to 15 strokes of Teflon head at $1500 \mathrm{rpm}$ on ice using a Glas-Col homogenizer. The homogenate was centrifuged at $800 \mathrm{~g}$ for $10 \mathrm{~min}$ and the pellet was re-extracted with $6 \mathrm{ml} \mathrm{MSE}$ and centrifuged again at 800 $\mathrm{g}$ for $10 \mathrm{~min}$ at $4{ }^{\circ} \mathrm{C}$. The two resulting supernatants were combined and centrifuged at 12,000 $\mathrm{g}$ for $30 \mathrm{~min}$ at $4{ }^{\circ} \mathrm{C}$ to give crude mitochondria at the pellet and cytoplasm in the supernatant. Crude mitochondria were suspended in $1 \mathrm{ml}$ MSE and placed on the top of a sucrose step gradient $(60,50,40,30$ and $20 \%, 2 \mathrm{ml}$ each) in which were centrifuged at 200,000 $\mathrm{g}$ for 30 min at $4{ }^{\circ} \mathrm{C}$ using a TH641 (Sorvall) swing out rotor. $0.5 \mathrm{ml}$ fractions were collected from the $40 \%$ and the $50 \%$ sucrose steps. The selected fractions were subjected to Western blotting to ensure the presence of mitochondria. The adenine nucleotide translocator 1 (ANT 1) was considered as a positive mitochondrial marker, while LAMP-1 protein and calsequestrin were considered as markers for late endosomes-lysosomes and endoplasmic reticulum respectively. Representative Western blots with antibodies against ANT 1 (sc 9300, Santa Cruz Biotechnology, 1:300 dilution), LAMP-1 (NB1952 from Novus Biologicals antibody at 1:400 dilution) and calsequestrin (sc 28274, Santa Cruz Biotechnology, 1:400 dilution) are shown in supplementary figure 3 for samples derived from cardiac muscle. Fractions positive for ANT 1 but negative for LAMP-1 and calsequestrin were considered as mitochondrial fractions (supplementary figure 3). This rationale and method were followed to isolate mitochondrial fractions from brain, heart and quadriceps muscle.

\section{Purification of $\Delta$ Trx2C93S interacting substrates}

Prior to adding to cell lysates, beads- $\Delta \operatorname{Trx} 2 \mathrm{C} 93 \mathrm{~S}(1 \mathrm{ml})$ were reduced with DTT $5 \mathrm{mM}$ for 30 min at RT in $20 \mathrm{mM}$ Tris-HCl, pH 8.0, $1 \mathrm{mM}$ EDTA, $0.2 \mathrm{M} \mathrm{KCl}$. Thereafter beads were transferred to a column and washed extensively in $50 \mathrm{mM}$ Tris-HCl, $1 \mathrm{mM}$ EDTA, $0.2 \mathrm{M}$ $\mathrm{KCl}, \mathrm{pH} 8.0$ to remove the DTT. $5 \mathrm{ml}$ of the lysate $(\sim 10 \mathrm{mg} / \mathrm{ml}$ protein $)$ in $50 \mathrm{mM}$ Tris-HCl, 1 mM EDTA, $0.2 \mathrm{M} \mathrm{KCl}$, pH 8.0 was added to solid phase $(1 \mathrm{ml})$ with bound $\Delta \operatorname{Trx} 2 \mathrm{C} 93 \mathrm{~S}$ and the slurry was left (in $15 \mathrm{ml}$ tubes) on a rocking platform at $4{ }^{\circ} \mathrm{C}$ overnight. To complete all nucleophilic attacks of any remaining thiolates of $\Delta \operatorname{Trx} 2 \mathrm{C} 93 \mathrm{~S}$ to possible substrates, selenite $(0.1 \mathrm{mM})$ was added the next day and the suspension was mildly rotated at room temperature for 1 hour after which it was transferred on a glass column. The flow through was discarded and the beads were washed extensively with $(2 \times 13 \mathrm{ml}) 50 \mathrm{mM}$ Tris-HCl, $1 \mathrm{mM}$ EDTA, $0.2 \mathrm{M}$ $\mathrm{KCl}, \mathrm{pH} 8.0$ (high salt wash), (13 ml) $20 \mathrm{mM}$ Hepes-KOH pH 8.0 (low salt wash), $50 \mathrm{mM}$ 
Tris-HCl, $1 \mathrm{mM}$ EDTA, $0.2 \mathrm{M} \mathrm{KCl,} \mathrm{pH} 8.01 \% \mathrm{v} / \mathrm{v}$ Triton X-100 (13 ml) (high salt wash with detergent) and finally with $20 \mathrm{mM}$ Hepes-KOH pH $8.0(4 \times 13 \mathrm{ml})$. At this stage, the first elution of non-covalently bound material (via hydrophobic interactions) was performed by adding $0.1 \mathrm{M}$ acetic acid-formic acid pH 2.1 (2x1 ml). Immediately after, $1 \mathrm{M}$ Tris- $\mathrm{HCl} \mathrm{pH}$ $9.0(0.4 \mathrm{ml})$ plus $20 \mathrm{mM}$ Hepes-KOH pH $8.0(1 \mathrm{ml})$ were sequentially added. The column was further washed with $20 \mathrm{mM}$ Hepes-KOH pH $8.0(4 \mathrm{ml})$ and the column temporarily gravity dried. All the above elutions were polled in the "acid wash" fraction (about $7.5 \mathrm{ml}$ ) to which $\mathrm{KOH} 10 \mathrm{M}(60 \mu \mathrm{l})$ were added to a final $\mathrm{pH}$ of $\sim 8$. The slightly dried column beads$\Delta \operatorname{Trx} 2 \mathrm{C} 93 \mathrm{~S}$ after the acid elution were transferred to a new tube $(15 \mathrm{ml})$ where $20 \mathrm{mM}$ Hepes-KOH pH 8.0 with $10 \mathrm{mM}$ DTT $(3 \mathrm{ml})$ were added. The slurry stood at RT for $1 \mathrm{~h}$ after which it was reloaded on a glass column and washed with $20 \mathrm{mM}$ Hepes-KOH pH $8.0(2 \times 4$ $\mathrm{ml}$ ). The whole $11 \mathrm{ml}$ constituted the "DTT fraction" corresponding to covalently bound material (via disulfide bonds) freed from the column by DTT reduction. Acid and DTT fractions were kept on ice. Their proteins were precipitated with TCA $(6 \% \mathrm{w} / \mathrm{v})$ and deoxycholate $(125 \mu \mathrm{g} / \mathrm{ml})$ [29], centrifuged (10.000 g, $\left.30 \mathrm{~min}, 4{ }^{\circ} \mathrm{C}\right)$, the resulting pellets were washed with acetone, methanol, resuspended in isoelectrofocusing buffer (IEF) and subjected to electrophoresis. All fractions resulting from the different elutions prior and after TCA precipitation were kept on ice.

\section{Electrophoretic separation of fractions}

Two dimensional separation of the purified fractions took place as follows: Samples were resuspended in IEF sample buffer (7 M urea, $2 \mathrm{M}$ thiourea, $50 \mathrm{mM}$ Tris- $\mathrm{HCl}, 2 \% \mathrm{CHAPS}$, $0.4 \%$ DTE, $0.1 \%$ bromophenol blue, $\mathrm{pH} 7.5$ ) including $3.6 \% \mathrm{v} / \mathrm{v}$ of protease inhibitors mix (Roche, Cat No: 11873580001) and loaded onto $7 \mathrm{~cm}$ strips pH 3-10 (Biorad) using cups. For the first dimensional separation a voltage of $4000 \mathrm{~V}$ was applied for a total run of $12,500 \mathrm{VH}$. Strips were then incubated for $15 \mathrm{~min}$ at room temperature with equilibration solution I (6 M urea, $50 \mathrm{mM}$ Tris-HCl, $\mathrm{pH}$ 8.8, $30 \%$ glycerol, $2.0 \%$ SDS, $30 \mathrm{mM}$ DTE) followed by a 15 min incubation with equilibration solution II (same composition as in solution I but with 230 $\mathrm{mM}$ iodoacetamide instead of DTE) for reduction and alkylation of the proteins. Strips were then applied on the top of $12.5 \%$ polyacrylamide mini gels, by the use of $0.5 \%$ agarose in TGS buffer and SDS-PAGE run at $40 \mathrm{~V}$ for $15 \mathrm{~min}$ followed by $80 \mathrm{~V}$ for 2 hours approximately. 2D gels were stained with colloidal Coomassie blue overnight and destained with ultra pure water. 


\section{Protein identification by MALDI-TOF-MS (Peptide Mass Fingerprinting)}

Following this procedure gels were scanned, spots were detected and excised. In gel-trypsin digestion was performed according to standard protocols. In brief, destaining of the excised spots took place by $30 \mathrm{~min}$ incubation in $150 \mu \mathrm{l}$ of destaining solution $(50 \mathrm{mM}$ ammonium hydrogen carbonate, $30 \%$ acetonitrile). Protein spots were then washed with $150 \mu 1$ ultra pure water twice and dried with the help of a vacuum centrifuge. Dried protein spots were trypsinized with the addition of $30 \mathrm{ng}$ trypsin (diluted in $10 \mathrm{mM}$ ammonium hydrogen carbonate $\mathrm{pH}$ 8.0) and overnight incubation at room temperature. Finally tryptic digests were extracted by the addition of $10 \mu \mathrm{l}$ extraction solution $(50 \% \mathrm{v} / \mathrm{v}$ acetonitrile, $0.1 \% \mathrm{v} / \mathrm{v}$ TFA) and 15 min incubation at room temperature. Peptide mixture $(1 \mu \mathrm{l})$ was applied on an anchor chip MALDI plate with $1 \mu \mathrm{l}$ matrix solution $(50 \% \mathrm{v} / \mathrm{v}$ acetonitrile, $0.1 \% \mathrm{v} / \mathrm{v}$ TFA, $0.025 \% \alpha-$ cyano-4-hydroxycinnamicacid) containing the peptides des-Arg-bradykinin (Sigma, 904.4681 Da) and adrenocorticotropic hormone fragment 18-39 (Sigma, 2465.1989 Da) as internal standards. Samples were analysed in a TOF mass spectrometer (Ultraflex, Bruker Daltonics, Bremen, Germany). Peak list was created with Flexanalysis v2.2 software by Bruker by summarizing 400 laser shots at intensity between 40 and $60 \%$. Smoothing was applied with Savitzky-Golay algorithm (width $0.2 \mathrm{~m} / \mathrm{z}$, cycle number 1). Signal to noise was calculated by SNAP algorithm and a threshold ratio of 2.5 was allowed. Peptide matching and protein searches were performed automatically with Mascot Server 2 (Matrix Science). The peptide masses were compared to the theoretical peptide masses of all available proteins from Mus musculus in the Swissprot database. Monoisotopic masses were used, 1 miscleavage site was calculated for trypsin proteolytic products, carbamidomethylation of cysteine was calculated as fixed and oxidation of methionine as variable modifications and finally a mass tolerance of 25 ppm was allowed.

\section{Isolation of thioredoxin interacting clones using the yeast two hybrid system}

cDNA libraries from human liver and rat brain were cloned into plasmid pGAD10 [LEU2, GAL4 (768-881)] (Clontech). All cDNA clones were therefore expressed as fusion proteins with the GAL4 activation domain (AD). The human Trx2 gene (without its mitochondrial signal, Trx2 starting as TTF) was cloned into the pGBT9y (Clontech) and expressed as a fusion protein with the DNA binding domain (BD) of the GAL4 transcriptional activator. The fusion site was verified by sequencing (not shown). pGBT9y also contained the gene for Amp resistance but in the place of the Leu gene (as in pGAD10) it contained the gene coding for tryptophan (Trp). The Trx2 gene was also cloned into the pAS2 vector which is similar to 
pGBT9y but with the ability to express higher amounts of GAL4-Trx2, allowing thus, the detection of weak protein interactions with $\operatorname{Trx} 2$. The pGBT9y/Trx2 construct was transformed into yeast HF7C cells. HF7C-pGBT9y/Trx2 cells surviving on plates without Trp were in addition transformed with the human liver or the rat brain library in pGAD10 plasmid using PEG/ lithium acetate. The yeast colonies growing on plates lacking Leu/Trp/His were numbered, picked with an inoculating loop and replated on plates lacking Leu/Trp/His. After three days at $30{ }^{\circ} \mathrm{C}$, growing (positive) colonies were collected and used for preparation of plasmid DNA which was electroporated into the HB 101 bacterial strain. Selection was on M9 Amp-containing plates lacking Leu. Plasmids from distinct growing colonies were isolated and transformed separately into yeast strain Y187 which grown on synthetic defined medium (SD) plates lacking Leu so that only cells containing the same pGAD10/cDNA clone would grow. Growing colonies from each plate were mated with pAS2/Trx2, HF7C yeast cells and spread on SD plates lacking Leu/Trp. All cells that grew contained the same pGAD10/cDNA clone and the pAS2/Trx 2 vector. cDNA inserts from the growing clones were sequenced and provided the genes presented in supplementary tables 2.2 and 2.3.

\section{Construction of the Trx2 interactome and diseasome.}

Human interactors of Trx2 were mined from the BioGRID web resource [26]. The mitochondrial topology of a protein species was according to Human MitoCarta2.0 (1158 mitochondrial genes [27]). The disease network (diseasome) uncovering disease-disease relationships was reconstructed by the Gene Prioritization and Evidence Collection (GPEC) plug-in of Cytoscape v.3.0.0 [30] taking into consideration the interactions between the mitochondrial Trx2 targets (MitoCarta and BioGRID) and the gene-disease associations retrieved from OMIM [31]. GO annotation of human proteins was performed by DAVID tool [32] and the ClueGO v.2.0.0 plug-in of Cytoscape as described previously [33, 34]. 


\section{Results}

\section{Construction of the interactome of human Trx2}

\section{Isolation and analysis of Trx2-interacting proteins by proteomics}

To isolate Trx2 interacting proteins, mouse total protein extracts from lung, kidney or skeletal muscle and mitochondrial extracts from mouse brain were initially left to interact overnight with Affi-Gel 15 coupled to $\Delta$ Trx2C93S. Next, the Affi-Gel slurry was loaded onto a column and washed with a succession of low and high salt washes. Two types of elutions followed. The first elution ("acid wash" by acetic/formic acid) aimed to the isolation of proteins bound strongly but in a non-covalent manner to Trx2. The second elution by DTT aimed at the proteins bound exclusively by a disulfide bond. The eluted proteins were visualized by 2D electrophoresis and picked and analysed by MALDI-TOF. Mouse mitochondrial extracts from cardiac and skeletal muscle were also used but analysed by 1D gels. The proteins identified using the two different elution methods from the different tissues and mitochondrial fractions are presented in supplementary tables 1.1-1.13. A synopsis of the proteomics results (supplementary tables 1.1-1.13) is presented in supplementary table 2.1 (176 protein species).

\section{Trx2-interacting proteins as revealed by Y2H screens}

A human liver cDNA library was used in $\mathrm{Y} 2 \mathrm{H}$ screens to isolate proteins interacting with Trx2. Approximately $16 \times 10^{6}$ clones were examined. 110 positive clones (growing on Leu/Trp/His) were analyzed. The Y2H screen of the human liver library gave 11 clones, all novel interacting partners for Trx2 (supplementary table 2.2). Another $\mathrm{Y} 2 \mathrm{H}$ screen using a cDNA library from rat brain, gave 7 novel interactors (supplementary table 2.3).

\section{Integration of the mouse, rat and published data for the construction of a probable interactome of human Trx2}

The information obtained from the mouse proteomics analysis and the human and rat $\mathrm{Y} 2 \mathrm{H}$ experiments were combined to construct an interactome for human Trx 2 . This is most likely a valid approach as mouse, rat and human Trx2 are practically identical (supplementary figure 1). The resulting combined interactome consisted of 195 proteins (Trx2 itself, plus 176 interactors from the proteomics approach, plus $11+7$ protein from the $\mathrm{Y} 2 \mathrm{H}$ screens, supplementary tables 2.1, 2.2, and 2.3), plus the mitochondrial 16S RNA. Inclusion of the 
known (BioGRID) human Trx2 interactome of 59 proteins (supplementary table 2.4) raised the interactome of human Trx 2 to 254 proteins (including Trx2), plus the mitochondrial $16 \mathrm{~S}$ RNA. Not a single protein species was common between the current and published data.

\section{Selection of Trx2-specific mitochondrial protein interactors}

As Trx2 is considered a mitochondrial protein, its potential interactors would be expected to be mitochondrial too. In the protocols used for the isolation of Trx 2 interactors, the total cell lysates used contained non-mitochondrial proteins, thus, a number of cytosolic proteins appeared interacting with Trx2 (supplementary table 2.1). The same applied for the $\mathrm{Y} 2 \mathrm{H}$ screens (supplementary tables 2.2, 2.3). To overcome these cytosolic interactions, we examined whether the proteomics approach would be more specific if only mitochondrial fractions were examined as the source of Trx2 interactors (supplementary tables 1.9-1.13). However, this approach did not achieve exclusive selectivity for mitochondrial interactors: in the case of the mitochondrial fractions isolated from brain (supplementary tables 1.9, 1.10, 2.1 combined acid and DTT elutions) for example, 16 out of a total of 26 protein species were mitochondrial according to the MitoCarta repository of proteins with strong evidence for mitochondrial localization (MitoCarta2.0 [27]). To overcome the apparently false cytosolic positives, all potential interactors of Trx 2 had their localization validated by MitoCarta. According to this approach, the novel mouse, human and rat mitochondrial Trx 2 interactors were 48 proteins, plus the mitochondrial 16S RNA (supplementary tables 2.1, 2.2, and 2.3; mitochondrial species in green background). Integration of these 48 proteins with the 4 known human mitochondrial interactors of Trx2 (combination of BioGRID [26] and MitoCarta2.0 [27]) raised the number of human mitochondrial protein species interacting with Trx 2 to 52 (table 1). The herein identified mitochondrial interactors included expected hits (peroxiredoxins, methionine sulfoxide reductase) but also proteins participating in the formation of iron sulfur clusters, protein folding in the mitochondrion, and proteins of lipid and carbohydrate metabolism. The novel findings regarding mitochondrial interactors and their potential significance to normal cellular function and disease are further elaborated in the "Discussion" section.

\section{General observations on the proteins that associated with Trx2}

A general outcome of the presented data (Fig. 1) is that almost the same number of protein species interacted covalently or non-covalently with Trx2. 19 mitochondrial interactors, were from non-covalent interactions (16 acid-eluted, 3 from $\mathrm{Y} 2 \mathrm{H}$ screens), 21 were of the covalent 
type, while 7 were common in covalent and non-covalent interactions. Most mitochondrialspecific interactions were derived from the proteomics experiments (46/182) while 3/19 were derived from the $\mathrm{Y} 2 \mathrm{H}$ screens and 4/59 from BioGRID. The highest number of interacting proteins was detected in lung lysates, a finding that may correlate with the higher levels of mRNA Trx2 in the tissue [35].

\section{The diseasome of human Trx2}

Any diseasome (disease network) links the phenotypic features of a disease (human disease phenome) to common molecular mechanisms such as genetic associations and/or protein interactions. Clustering of disease phenotypes is likely due to underlying common pathophysiology mechanisms [36]. Diseasome analysis by the GPEC plug-in of Cytoscape for the mitochondrial interactome of $\operatorname{Trx} 2$ showed that the genes encoding $\operatorname{Trx} 2$ and its interactors were directly associated with ten different diseases forming four cliques (Figure 2, supplementary table 2.5 ). 


\section{Discussion}

The acceptors of the flow of electrons via thioredoxins are per se the interacting partners of thioredoxins and constitute the "classical" thiol-reacting substrates such as ribonucleotide reductases, methionine sulfoxide reductases etc. These interactions are fast covalent exchanges of electrons via the active site thiols of thioredoxins and should in principle be detected by a monothiol thioredoxin species. As thioredoxins may associate non-covalently with other proteins, $\mathrm{Y} 2 \mathrm{H}$ approaches should be able to detect this type of interactions. Up till now, 59 interactors for human Trx2 are described in the BioGRID interaction repository, with only four of them being mitochondrial (MitoCarta2.0). Using a proteomics approach combined with $\mathrm{Y} 2 \mathrm{H}$ screens, the potential mitochondrial interactome of Trx2 was increased herein by 49 additional interactors.

\section{Novelty of the method}

While the general principle of the monothiol trapping method has been used for other thioredoxins/glutaredoxins, the current approach differed in subtle aspects. First, immobilization of Trx 2 was not directly on activated Sepharose beads but on Affi-Gel resin via a 15 carbon spacer to reduce steric hindrance preventing the interaction of thioredoxin with ligands: binding of EcoTrx1 directly on dextran via N-hydroxy succinimide esters, greatly limited its interaction with gene 5 protein of phage T7 [37]. By adding a spacer of six extra carbons (6-amino- $n$-hexanoic acid), the hindrance was eliminated [37]. Second, the method detected proteins interacting strongly with $\operatorname{Trx} 2$ in a non-covalent manner that were removed from Trx 2 prior to the reducing step (the latter detecting covalent interactions with Trx2) by a succession of low and high salt washes, finally followed by an acid wash to detect strong hydrophobic interactions. Such washing protocols are used for the affinity purification of antibodies ( $\mathrm{K}_{\mathrm{D}} \mathrm{S}$ in the low $\mathrm{nM}$ range) and in the present case gave a significant number of potential interactors (almost $50 \%$ of total interactome), that might have been overlooked or misinterpreted by a disulfide reducing protocols aiming at the specific detection of covalent redox (S-S) interactions. In addition, acid treatment before reduction increased the specificity of the method for the following detection of S-S covalent interactions. Third, selenite was employed to force the oxidative interaction of thioredoxin and ensure the nucleophilic attack to its potential substrates as the compound is a fast oxidant of the thioredoxin system [38]. Fourth, the amounts of protein used in the interaction experiments were generally high for 
immobilised Trx2 and lysates to enhance interactions. Finally, material from different tissues was examined, to include the possible tissue-specific expression patterns of potential interactors of Trx2. Apart from the suggested novel interactors (table 1), the greater emerging concept for the Trx 2 interactome is that the number of non-covalent interactors is as much if not greater than the number of the covalent ones (figure 1). Assuming some degree of complementarity between the shapes of Trx 2 and its interactors, we propose three major types of interactions (Fig. 3): (i) somewhat weak ionic (Fig. 3A), mostly not detected here due to the preceding relatively high salt washes; (ii) strong hydrophobic as revealed by the acidic elutions (Fig. 3B); (iii) covalent (SS bonds, Fig. 3C) due to the thiol oxidoreductase activity of Trx2. The hypothesis should not exclude mixed types of interactions between the contact areas (e.g. mostly hydrophobic and ionic to a lesser extent etc).

\section{On the specificity of the detected interactions}

The immediate concern of the applied approach is whether the monothiol motif within the substrate contact area of Trx 2 could select for specific interactors. In the case of EcoTrx 1 with 3'-phosphoadenosine 5'-phosphosulfate reductase, the interaction was not dependent on the exact active site sequence $(\mathrm{CxxC})$ of thioredoxin but on complementarities in geometry and charges in the contact areas of the two molecules [39]. This finding showed that the very strict characteristics of thioredoxin structure dictate themselves the interaction with specific substrates. Fine details on the catalytic mechanism of thioredoxins revealed that it differed among these oxidoreductases [40]: while all thioredoxins apparently use the MichaelisMenten mechanism, the eukaryotic species (mithochondrial Trx2 excluded) may also apply single-electron transfer reactions (SET) [40]. Prokaryotic thioredoxins and mitochondrial Trx2 reduce their substrates by nucleophilic substitution $\left(\mathrm{S}_{\mathrm{N}} 2\right)$ and SET reactions [40]. The difference in the reductions mechanism were explained in view of the deeper substrate binding groove of eukaryotic thioredoxins compared to the more shallow one of the prokaryotic enzymes and Trx2 [40].

Under the previous considerations, the overall structure of monothiol Trx 2 used herein for monothiol trapping should have been able to recognize specific interactors. However, the mitochondrial interactors identified by the proteomics approach were 46 out of 176 . In BioGRID, the common interactors between Trx1 and 2 (147 and 59 interactors respectivly) were eight proteins, suggesting increased specificity for each thioredoxin species. Perhaps, the considered non-specific cytosolic interactors of Trx2 (supplementary table 2.1) could be envisaged as a bycatch of the contact area of a mitochondrial protein exposed to the cytosol 
and interacting with complementary surfaces of cytosolic proteins. In case that Trx2 may have hitherto unidentified splicing variants without the mitochondrial targeting sequence, these interactions could be significant: the splice isoforms the TXN2 gene have not been analysed for all types of cells. In any case, the monothiol method picked bona fide interactors of Trxs (e.g. mitochondrial peroxiredoxins, mitochondrial methionine sulfoxide reductase), while classic substrates of Trx1 such as ribonucleotide reductase and cytosolic methionine sulfoxide reductase, were not selected. The latter could reflect the afore-mentioned structural characteristics conferring exclusive specificity on $\operatorname{Trx} 2$, or the reducing action of alternative disulfide reductants (the glutaredoxin system or the action of cytosolic Trx1), preventing the formation of the complexes in total cell lysates. Considering the likelihood that the high amounts of Trx 2 immobilized on the affinity columns should compete with interferences from other redoxins, the mentioned subtleties in thioredoxin specificity, and the currently believed mitochondrial localisation of Trx2, it could well be that at least the mitochondrial interactors of table 1 represent specific findings of functional significance.

\section{Implications on the possible cellular functions of Trx2 in view of the proposed specific interactions}

\section{Mitochondrial integrity}

MICOS complex subunit Mic60 (IMMT) is one of the major subunits of the mitochondrial intermembrane space bridging complex that is involved in the invaginative folding of inner mitochondrial membranes into cristae [41]. The possible interaction of Trx2 with IMMT suggests the involvement of Trx2 in maintaining the inner mitochondrial membrane structure. Mitochondrial inorganic pyrophosphatase 2 (PPA2) hydrolyzes inorganic pyrophosphate to pyrophosphate, an essential activity for the regulation of a proper mitochondrial membrane potential, organization and function. PPA2 mutations are pathogenic and can be related to cardiomyopathy [42]. Overexpression of $\operatorname{Trx} 1$ [43], or $\operatorname{Trx} 2$ [44, 45] prevent oxidative damage to the heart, while ablation of the TrxR2 in mice resulted in fatal dilated cardiomyopathy [46]. Our data suggest that Trx2 could be the linked to cardiomyopathy via TrxR2 and PPA2.

\section{Formation of iron-sulfur clusters}

A number of proteins participating in iron-sulfur cluster formation were associated with Trx2. The mitochondrial Stress-70 protein (HSPA9, Uniprot ID: P38646), is a chaperone involved 
with iron-sulfur cluster (ISC) biogenesis that occurs exclusively in mitochondria [47]. It interacts with and stabilizes ISC cluster assembly proteins frataxin (FXN, the prokaryotic CyaY, an iron donor), NFU1 (maturation of lipoate synthase and succinate dehydrogenase, prokaryotic equivalents are the C-terminal domains of NifU, NfuA, both scaffold proteins), cysteine desulfurase NFS1 (the equivalent of IscS, a sulfur donor) and ISCU (a scaffold protein for Fe/S cluster synthesis) [47, 48]. Therefore, HSP9 is a central protein in ISC biogenesis whose depletion causes a deficit in mitochondrial ISCs ultimately affecting heme synthesis and differentiation of red blood cells [48, 49]. Its herein detected interaction with Trx2 raises the possibility that the activity of HSP9, hence Fe/S cluster biogenesis (and heme synthesis) in mitochondria may be affected by Trx2. Apart from HSPA9, Trx2 interacted with the $\mathrm{Fe} / \mathrm{S}$ cluster containing proteins NDUFS2, NDUFS3, and NDUFV1. In the super molecular assembly of the human mitochondrial respiratory mega complex [50], NDUFS3 and NDUFV1 appear accessible to solvent and thus could in principle interact with Trx2. It is tempting to assume that the interaction of Trx 2 with these proteins would result in the reduction of their cysteines in a step related to protein folding or the formation/assembly or rearrangement of their iron-sulfur clusters. In fission yeast, the mitochondrial Trx2 system could affect the activity of Fe-S proteins (such as mitochondrial aconitase and cytosolic sulfite reductase but not succinate dehydrogenase) by lowering the levels of free cellular iron [51]. EcoTrx1 along with TrxR were able to supply iron specifically to IscA, the protein (with NFS1 as the eukaryotic homologue) that may provide iron for normal Fe/S cluster assembly on IscU [52]. The mitochondrial Trx2 system could thus affect iron sulfur cluster biogenesis by (i) affecting the activity of HSPA9 (ii) affecting the redox state of cysteines in specific Fe$\mathrm{S}$ enzymes and indirectly by (iii) having an impact on free Fe supply [51]. The proposed interaction of HSPA9 with Trx2 implicates the latter with sideroblastic anemia, the inability to insert iron in the heme of hemoglobin resulting in the characteristic altered phenotype of red blood cells [53].

\section{Oxidative stress}

Superoxide generated from stray electrons of the electron transport chain may be reduced by superoxide dismutases (SODs) to generate hydrogen peroxide $\left(\mathrm{H}_{2} \mathrm{O}_{2}\right)$ that may promote oxidative stress via formation of hydroxyl radicals by the Fenton reaction ([54] and references therein). Trx2 could itself reduce $\mathrm{H}_{2} \mathrm{O}_{2}$ to $\mathrm{H}_{2} \mathrm{O}$ at low rates but is considered as the main electron donor to peroxiredoxins (Prx) 3 and 5 who together with glutathione peroxidases 1 and 4 are on top of the hierarchy for the reduction of $\mathrm{H}_{2} \mathrm{O}_{2}$ in cells [55]. The central role of 
Prx3 in detoxifying $\mathrm{H}_{2} \mathrm{O}_{2}$ has been demonstrated for cell lines [56] and transgenic mice [57]. Trx2 is the main reductant of Prx3 in mitochondria [58] while human glutaredoxin 2 (hGrx2) may also reduce Prx3 but with lower (double Km) catalytic efficiency. Trx2 (but not hGrx2) may also reduce Prx5 [59], although the complex of a mutated Trx2C93S did not form stable complexes with Prx5 as it did with Prx3 [60]. Cytosolic human Trx 1 can reduce Prx3 and Prx 5 with better kinetics than Trx2 [59] but this interaction is not likely to happen due to the different compartmentalization of the two thioredoxins. Levels of $\mathrm{H}_{2} \mathrm{O}_{2}$ were elevated when auranofin, an inhibitor of TrxRs was applied in mouse mitochondrial extracts concomitant with increased levels of oxidized Trx2, Prx3 and ROS (as detected by MitoSOX) [61]. Thus, an intact mitochondrial TrxR2 was essential for the reduction of $\mathrm{H}_{2} \mathrm{O}_{2}$. The participation of Trx2 is not limited to the elimination of $\mathrm{H}_{2} \mathrm{O}_{2}$ via $\operatorname{Prx} 3$ but also to inhibition of apoptosis: knockdown of Trx2 in lung epithelial cells growing in hyperoxia increased the phosphorylation of ASK1 due to lack of reduced Trx2 binding to it and preventing the serine/threonine kinase activity of ASK1 [62]. In the current work, all peroxiredoxins were picked up as interactors of Trx2. This finding, as well as the interactions with mitochondrial methionine sulfoxide reductase (MSRA) validates the method used. In addition, we present the possible interaction of Trx2 with the peroxisomal bifunctional enzyme (EHHADH) that normally participates in fatty acid $\beta$-oxidation by $\mathrm{NAD}^{+}$. Absence of $\mathrm{EHHADH}$ is related to peroxisomal disorders as the enzyme may affect catalase activity and thus the elimination of $\mathrm{H}_{2} \mathrm{O}_{2}$ produced by the $\beta$-oxidation of fatty acids [63].

Trx2 is considered interacting with SOD1 (BioGRID) implicating further Trx 2 with reactions involving $\mathrm{H}_{2} \mathrm{O}_{2}$ and amyotrophic lateral sclerosis [64]. More than a hundred mutations in the human sodl have been associated with familial ALS [65]. Reduction of mutant SOD1s by Trx2 1was followed by the formation of aggregates via interaction of the reduced Cys ${ }^{57}$. $\mathrm{Cys}^{146}$ thiols of SOD1s with the $\mathrm{Cys}^{6}$ and Cys ${ }^{111}$ thiols of neighbouring SOD1s [66]. The toxic effects of mutant SOD1s are considered as a consequence of formation of soluble or insoluble oligomers [67]. In full agreement with the antioxidant functions of Trx2, increased oxidative stress was evident in mitochondria of haploid mice for TXN2 [68].

\section{Detoxification from aldehydes}

Trx2 interacted with two detoxifying enzymes: carbonyl reductase [NADPH] 3 (CBR3) and aldehyde dehydrogenase 2 (ALDH2). Aldehyde dehydrogenases catalyse the reduction of aldehydes to carboxylic acids and participate in different biological processes including detoxification. The herein identified partner of Trx2 ALDH2, is crucial for the oxidation of 
toxic biogenic aldehydes (e.g. acetaldehyde, catecholaminergic metabolites including DOPAL and DOPEGAL and the principal product of lipid peroxidation 4-HNE) to harmless products [69]. Mutations compromising the catalytic activity of mitochondrial ALDH2 are responsible for increased susceptibility to alcohol intoxication and increased cancer risk due to alcohol consumption [70]. Because of its central role as a phase 1 detoxifying enzyme, dysfunction of ALDH2 has been related to many human diseases and pathologies [71]. The activity of the enzyme may be inhibited by high concentrations of aldehydes such as those occurring at Parkinson's disease [72]. The detoxification of 4-HNE, which is at the beginning of signaling cascades leading to Alzheimer's disease, is dependent on ALDH2 [69]. Activation of ALDH2 has even been proposed as a therapeutic approach for Parkinson's disease [69]. The activity of ALDH2 is redox sensitive: 6-methoxy-2-naphthylaldehyde oxidation by ALDH2 was stimulated by addition of DTT either/or TrxR1 and Trx1 [73]. As TrxR1 and Trx1 are normally cytosolic, these findings most likely reflect the interaction of the mitochondrial thioredoxin system with ALDH2.

CBR3 belongs to the category of monomeric carbonyl reductases that catalyze the reduction of carbonyls in endogenous and xenobiotic compounds, including steroids and prostaglandins [74]. The latter activities are specific for the abundant human CBR1 but not for the highly homologous, less transcribed CBR3 that remains an enigmatic enzyme in terms of substrate specificity and cellular function [74]. CBR3 is somewhat abundant in lung, liver, spleen, pancreas, intestine, and more abundant in the ovary [74]. Trx2 that is known to be inhibited by cyclopentenone-type prostaglandins [75] interacted in the present work covalently with CBR3 from lung tissue preparations. The significance of the proposed interaction between Trx 2 and CBR3 is not obvious.

\section{Protein synthesis}

Trx2 is likely to participate in protein synthesis via its detected interactions with the mitochondrial $16 \mathrm{~S}$ ribosomal RNA gene (identified here by a $\mathrm{Y} 2 \mathrm{H}$ screen), the $40 \mathrm{~S}$ ribosomal protein S18 (RPS18 gene product) and the mitochondrial elongation factor $\mathrm{Tu}$ (mEF-Tu, TUFM gene product). The mitochondrial 16S ribosomal RNA gene is essential for protein synthesis. RPS18 (40S ribosomal protein S18) is a protein of the small ribosomal subunit [76] that has also been identified as an mRNA binding protein [77]. The interaction of the two proteins with $\operatorname{Tr} 22$ raises the possibility of the participation of the latter in mitoribosomal assembly. There has been a possible lingering association between thioredoxins and EF-Tu: (i) EcoTrx 1 and EF-Tu belong to the same osmotically-sensitive compartment [78]; (ii) EF- 
Tu has thioredoxin/protein-disulfide isomerase activity (reduction of insulin) that is dependent on DTT [79]; (iii) Inactive oxidised EF-Tu is reactivated after reduction by thioredoxin [80]. In line to previous publications, this work implies the reduction and therefore concomitant activation of mEF-Tu by Trx 2 .

\section{Protein folding in the mitochondrion}

The mitochondrial $60 \mathrm{kDa}$ heat shock protein (HSPD1) together with HSP10 (HSPE1) are implicated in the import, folding and assembly of proteins in the mitochondrial matrix (Uniprot ID: P10809). Hsp60 forms heptameric rings [81] in which protein folding may occur [82]. Hsp60 and Hsp10 are the structural and functional equivalents of prokaryotic GroEL [83] and GroES [84] respectively. HSPD1 rings are properly folded in the mitochondria by the concerted action of the HSP9-Hsp10 complex that binds to the unassembled Hsp60 precursor to promote its assembly into mature Hsp60 complexes [85]. The association of Trx2 with this cytosolic pathway (and PDI or P07237, table 1) points to the direction of Trx 2 being involved in the folding of mitochondrial proteins.

\section{ADP-ribosylation}

Trx2 associated with O-acetyl-ADP-ribose deacetylase MACROD1 (also known as LRP16) that confers post translational modification of the ADP-ribosylation type. The latter is a reversible post-translational modification with wide-ranging biological implications [86]. LRP16/ MACROD1 may hydrolyse the ester bonds forming between glutamate residues in proteins [87] or phosphorylated double-stranded DNA ends and a single ADP-ribose moiety [88]. MACROD1 may interact with estrogen receptor alpha (ER $\alpha)$ [89] and integrate into the NF- $\kappa B$ transcriptional complex and activate it [89]. Trx 2 may also interact directly with the p65 subunit of NF- $\kappa$ B [90], while Trx1 may associate with DNA-bound ER $\alpha$ [91]. These observations bring into proximity MACROD1 and Trx2 and suggest that the covalent interaction observed in this work may be of physiological significance and implicate Trx 2 in ADP-ribosylation.

\section{Glycolysis}

Trx2 was associated with triosephosphate isomerase (TPI), glyceraldehyde 3-phosphate dehydrogenase (GAPDH) and lactate dehydrogenases (LDHs) of the glycolytic cycle. TPI catalyzes the reversible interconversion of dihydroxyacetone phosphate and D-glyceraldehyde 3-phosphate in glycolysis [92]. Several studies show that TPI is a target for different plant 
thioredoxins and EcoTrx1 ([93] and references therein), making it highly possible that the protein may indeed interact with mammalian Trx 1 or Trx2. TPI is of mitochondrial localization in 14 tissues reported in the Human MitoCarta2.0 [27], while cytosolic TPI may have evolved from the mitochondrial form [94]. Therefore, the presently reported covalent and non-covalent interaction of TPI with Trx 2 could well mean that TPI may interact in vivo with Trx2. The potential interactions of Trx 2 with TPI introduces a potential role of Trx 2 in the pathogenesis of triosephosphate isomerase deficiency [95] (Fig. 2).

Glyceraldehyde 3-phosphate dehydrogenase (GAPDH), had high prevalence of interaction with Trx2 in different tissues (4 hits, supplementary table 2.1). The cytosolic thioredoxin of Plasmodium falciparum [96], EcoTrx1 and plant thioredoxins are known to interact with GAPDH ([93] and references therein). In the case of Arabidopsis thaliana cytosolic GAPDH thioredoxin/glutaredoxin could reduce a mixed disulfide forming between GSH and an exposed catalytic cysteine ( $\mathrm{Cys}^{149}$ ), crucial for enzyme function [97]. Trx1 could denitrosylate the active site Cys ${ }^{152}$ of human GAPDH and thus control the pool of free heme [98]. Human Trx1 could also act as an S-desulfhydrase on human GAPDH with the activity residing on the attacking $\mathrm{Cys}^{32}$ of Trx1 [99]. Trx1 alone or in combination with TrxR1 and $\alpha$ crystallin were able to revive the activity of GADPH in the cortex and nucleus from cataract lenses [100], although the exact mechanism is not known. These observations may validate (via Trx1) our data regarding the interaction of Trx 2 with GAPDH. Both GAPDH and $\alpha$ crystalline B chain were identified as potential targets of Trx 2 suggesting that redox interactions between Trx 2 with $\alpha$ crystallin and GAPDH may occur simultaneously.

Lactate dehydrogenases (LDHs) A (cytosolic) and B (cytosolic and mitochondrial localization) are glycolytic enzymes that catalyze the reversible oxidation of lactate to pyruvate coupled to the concomitant reduction of $\mathrm{NAD}^{+}$to $\mathrm{NADH}$. In the case of LDHD (exclusive mitochondrial localization Uniprot ID: Q86WU2) the electrons for the reduction are derived from ferricytochrome $\mathrm{c}$ that is oxidized to ferrocytochrome. The balance of lactate/pyruvate levels may affect levels of intracellular NADH and thus the activity of NADPH oxidase (production of superoxide when higher levels of NADH and lactate) [101]. Higher pyruvate levels can thus promote a reduced intracellular environment [102]. In addition, lactate can enhance hydroxyl radical formation by the Fenton reaction [103]. High LDH levels are thus considered cytotoxic [104]. Higher lactate levels lead to elevation of Trx 1 resulting in HIF-1 increase and synthesis of HIF-1-dependent growth factors [105]. The 
high reactivity (inhibition) of ebselen with LDH from heart and liver homogenates [106] suggests that LDHs may react with nucleophiles such as thiols. This work presented evidence of possible interactions of the three LDHs with Trx2 (LDHA: non-covalent, LDHB: noncovalent, LDHD: covalent). Considering the promotion of an oxidative environment by LDHs, such interactions would seem biologically logical as a means of interfering directly with the activity of LDHs. In addition, the proposed interaction of Trx 2 with LDHB raises the possibility of Trx2 being involved in LDHB deficiency although the condition appears non pathogenic (OMIM entry 614128).

\section{Pyruvate dehydrogenase activity}

The enzyme complex of pyruvate dehydrogenase catalyzes the decarboxylation of pyruvate to acetyl-CoA [107, 108], linking the glycolytic pathway to the tricarboxylic cycle [109]. It consists of the E1 (pyruvate dehydrogenase activity), the E2 (dihydrolipoamide acetyltransferase) and the E3 (lipoamide dehydrogenase) components ([109], https://www.ebi.ac.uk/interpro/entry/IPR027110). The human E1 component is a heterotetramer of the $\alpha_{2} \beta_{2}$ type ( $\alpha=$ PDHA1 and $\beta=$ PDHB) with two catalytic sites [107]. It contains thiamine pyrophosphate as a co factor and catalyses the rate limiting step of the whole reaction [110]. To our knowledge, there is no reported direct interaction of any component of the thioredoxin system with any member of the pyruvate dehydrogenase complex. EcoTrx1 could reduce in vitro the disulfides of insulin after receiving electrons from reduced lipoamide [111], a cofactor of the E2 component. However, suppressor mutants of the lipoamide dehydrogenase gene in E. coli showed that glutaredoxin 1 (and not EcoTrx1) was able to transfer electrons from oxidized lipoamide to ribonucleotide reductase [112]. Herein, Trx2 was associated to the E1 component subunits PDHA1 and PDHB in a noncovalent and covalent manner respectively. The active site loops of PDHA1 (E1 component subunit alpha) and PDH (E1 component subunit beta) are flexible and may affect the activity of $E 1[107,108,113]$. The detected interaction of $\operatorname{Trx} 2$ could perhaps modify their flexibility resulting in alterations of the active sites of E1, raising the possibility of regulation of the whole activity of eukaryotic pyruvate dehydrogenase by the thioredoxin system. The two systems are interconnected in terms of electron transfer as the pyruvate dehydrogenase complex may provide electrons to mitochondrial TrxR via the mitochondrial membrane nicotinamide nucleotide transhydrogenase [114]. The proposed interactions of Trx2 with PDHA1 and PDHB implicate the protein with pyruvate dehydrogenase complex deficiencies (entries 300502 and 179060 respectively in the OMIM data base: www.omim.org). 
Trx2 interacted covalently with nucleoside diphosphate-linked moiety X motif 19 (NUDT19) that may hydrolyze in vitro the diphosphate bond of free CoA and acyl-CoAs to form 3',5'ADP and 4'-(acyl)phosphopantetheine, while it contributes to the regulation of CoA levels in the kidney in vivo [115]. The interaction of Trx2 with NUDT19 implicates the thioredoxin system in pathways utilizing CoA (the proposed relations of Trx 2 with lipid metabolism will be commented later).

\section{TCA cycle}

Trx2 interacted with mitochondrial aconitate hydratase (aconitase, ACO2) that catalyzes the stereo-specific isomerization of citrate to isocitrate via cis-aconitate in the subpathway synthesizing isocitrate from oxaloacetate in the citric acid cycle. Aconitase contains [4Fe-4S] clusters that do not participate in electron flow but may reversibly loose one Fe atom to obtain a [3Fe-4S] cluster (apo aconitase). In E. coli, the cluster is delivered by IscU [116]. In conditions of low iron, apo aconitase may bind to the mRNA of iron responsive elements [117] associated with iron metabolism [118]. In E. coli, the respective enzyme binds to its own mRNA and stabilizes it [119]. Mutations in the human gene may result in vision defects [120], while loss of Fe in wild type enzyme due to smoking related oxidants may result in increased iron deposition in arterial cells [121]. In fission yeast, overexpression of Trx2 (but not cytosolic Trx1) was able to restore aconitase activity in glutathione reductase depleted cells, most likely by regulating the levels of free iron [51]. The detected interaction of Trx2 with mitochondrial aconitase suggests that Trx 2 may reduce a disulfide forming between the three cysteine residues comprising the coordination site for the Fe-S cluster, allowing thus normal coordination of the cluster.

Trx2 interacted non-covalently with human isocitrate dehydrogenases 1, 2 and 3 (IDH1, 2, $3 \mathrm{G})$ and covalently with IDH3A. The enzymes catalyze the oxidative decarboxylation of isocitrate to alpha-ketoglutarate in the citric acid cycle. In the reaction, IDH1 and IDH2 reduce $\mathrm{NADP}^{+}$to $\mathrm{NADPH}$, whereas IDH3 reduces $\mathrm{NAD}^{+}$to $\mathrm{NADH}[122,123]$. IDH1 is regarded as cytosolic (although also described with mitochondrial localization [27]), whereas IDH2 and 3 are considered strictly mitochondrial. Due to its role in replenishing NADPH pools, IDH2 may supply electrons for the reduction of mitochondrial TrxR and oxidized glutathione, affecting thus the activity of glutathione peroxidase [123]. Null mutants for Idh2 had increased loss of hair cells and neurons in the cochlea of male mice due to oxidative stress resulting from a defective mitochondrial thioredoxin system [122]. The interaction of Trx2 
with IDH2 could affect the activity of the latter. The possible implication is a feedback between the thioredoxin system and IDH2.

IDH3G may form part of the heterotetramer of IDH3 which has an $\alpha_{2} \beta \gamma$ composition with $\alpha$ being IDH3A, $\beta$ IDH3B and $\gamma$ IDH3G, the allosteric activator of the complex [124]. In this work, Trx2 could interact with IDH3G non- covalently introducing the possibility of an additional, redox regulation of the allosteric activator component IDH3G of IDH3. In E. coli, EcoTrx1 is known to associate with isocitrate dehydrogenase (ICD) [17]. ICD shows an approximately $30 \%$ identity to subunits $\alpha$ (IDH3A) and $\beta$ (IDH3B) and $24 \%$ to IDH3G.

Apart from its interactions with the E1 component subunits PDHA1 and PDHB of pyruvate dehydrogenase, Trx2 interacted non-covalently with IDH1. Since mutant IDH1 perturbs the normal metabolism of pyruvate in glioblastoma cells [125], Trx2 could be affecting pyruvate metabolism by IDHs, PDHA1 and PDHB.

\section{Electron transport chain}

\section{Complex I}

Complex I is a large L-shaped protein complex (almost $1000 \mathrm{kDa}$ [126]), composed of three domains: a dehydrogenase domain ( $\mathrm{N}$ module) and a hydrogenase domain ( $\mathrm{Q}$ module) both located at the mitochondrial matrix, and a transmembrane part (P module) located on the inner mitochondrial membrane $[126,127]$. Electrons from NADH (produced from the Krebs cycle) are transferred to the dehydrogenase domain ( $\mathrm{N}$ module), then to the hydrogenase domain $(\mathrm{Q}$ module) where reduction of coenzyme Q10 $\left(\mathrm{CoQH}_{2}\right)$ is performed. The reduction is followed by translocation of protons from the mitochondrial matrix to the intramembrane space by the transmembrane part (P module), resulting in formation of a proton gradient.

Trx2 bound non-covalently to NDUFS1, 2, 3 and NDUFV1, all iron-sulfur cluster containing proteins of the Q module [126]. NDUFS3 along with NDUFS2 [128] initiate the in vivo assembly of Complex-I subunits in the mitochondrial matrix [129]. The detected interactions with NDUFS1, 2 and 3 imply a possible contribution of $\operatorname{Trx} 2$ to the functional and structural integrity of Complex I.

\section{Complex II}

Trx2 interacted non-covalently with SDHA, the flavoprotein (FP) subunit of the enzyme complex of succinate dehydrogenase (SDH), or respiratory Complex II. SDHA is located at the mitochondrial matrix and catalyses the oxidation of succinate to fumarate. The electrons 
abstracted, travel via the iron sulfur clusters of adjacent SDHB, to the inner mitochondrial membrane located SDHC and SDHD that reduce $\mathrm{CoQ}$ to $\mathrm{CoQH}_{2}$ (exemplified for the enzyme from E. coli [130]). The result is an increase of the $\mathrm{CoQH}_{2}$ pool that transfers electrons to the cytochrome bc1 complex (complex III) that in succession relocates electrons to complex IV for the reduction of molecular oxygen to water [131]. A defective SDHA resulted in elevated succinate levels that activated mitochondrial TrxR2 [132]. This finding implicates further the potential interaction of Trx2 with SDHA for the reduction of CoQ in mitochondria and pinpoints TrxR2 as a possible target for the modulation of the electron chain: inhibitors of TrxR2 could affect the normal function of the electron chain at the levels of complex II, possibly via Trx2.

\section{Complex III}

Trx2 apparently interacted with UQCRC1 (covalently) and UQCRC2 (non-covalently), both core subunit proteins of the mitochondrial cytochrome b-c1 complex (complex III) of the electron transport chain that catalyzes the reduction of cytochrome $c$ by oxidation of $\mathrm{CoQH}_{2}$ to $\mathrm{CoQ}$ with simultaneous transfer of protons from the mitochondrial matrix to the intermembrane space [133]. Complex III contains 3 additional respiratory subunits (cytochrome b, cytochrome $\mathrm{c} 1$ and Rieske/UQCRFS1) and 6 low-molecular weight proteins. UQCRC1 may mediate formation of the complex between cytochromes c and c1 (Uniprot ID: P31930, [134]), while its normal function is required for spermatogenesis [135]. Overexpression of UQCRC1 may affect mitochondrial morphology/physiology and may lead to development of obesity [136]. UQCRC2 contributes to the assembly of complex III (Uniprot ID: P22695) and may be involved in carcinogenesis [137-139].

Trx2 interacted covalently and non-covalently in brain extracts with UQCRFS1, whose incorporation is the penultimate step in the biogenesis of complex III [140]. Dysfunction of the latter is related to neurological diseases.

\section{Complex IV}

Trx2 interacted with cytochrome c oxidase (complex IV) subunits MT-CO1 (cytochrome c oxidase subunit 1 or COX1, data from Y2H) and NDUFA4 (non-covalent binding, proteomics data) of complex IV. MT-CO1 is one of the three core components, (the other two being, $\mathrm{COX} 2$, and COX3) that form the core of cytochrome oxidase. COX1 is the nucleus for the biogenesis process of complex IV to which imported subunits (including COX2 and COX3), associate and assemble in a sequential manner [141, 142]. NDUFA4 is required for normal 
activity of complex IV [143]. Mutant forms of NDUFA4 may give the neurological phenotype of the Leigh Syndrome [144].

We did not detect any binding of $\operatorname{Trx} 2$ to cytochrome $\mathrm{c}$ as has been observed in immunoprecipitations [145]. In a previous work, cytochrome c was a substrate for TrxR2 that reduced the protein in vitro with similar efficiency in the presence or absence of Trx2 [146] suggesting that Trx2 may not reduce cytochrome c.

\section{ATP synthase and Trx2}

The most hits for Trx 2 interactions from different tissues were for the $\beta$ subunit of mitochondrial ATP synthase (ATP5B), while the $\alpha$ subunit (ATP5A) was in the second position (with peroxiredoxin 6). These subunits form a structure within the $F_{1}$ domain located in the mitochondrial matrix that binds to ADP to form ATP from the proton gradient that generates a torque on the $\mathrm{F}_{0}$ domain where the transmembrane rotating c-ring is located ([147] and references therein). Trx2 interacted also covalently with the subunit d of ATP synthase that is part of the peripheral stalk connecting the $F_{1}$ and $F_{0}$ domains [147]. Although we found reports for redox regulation of the gamma subunit of the $F_{1}$ domain [148-150], no data were available for such a mechanism for the alpha and beta subunits. The evidence presented herein, raises this possibility which is likely to be validated by previous work in which overexpression of Trx2 in HEK293 cells was specifically affecting the activity of ATP synthase and therefore, the potential of the mitochondrial membrane [35].

Another possible association of Trx2 with ATP levels is via S-type mitochondrial creatine kinase (CKMT2) with which Trx2 was covalently associated. CKMT2 reversibly catalyzes the transfer of phosphate between ATP and various phosphogens (e.g. creatine phosphate). CKMT2 isoenzymes are involved in energy transduction in tissues with large and fluctuating energy demands (e.g. skeletal muscle, heart, brain, spermatozoa, Uniprot ID: P17540).

Overall, interactors of Trx 2 were found in all complexes of the electron transport chain. It is not therefore surprising that the protein is related to combined oxidative phosphorylation deficiency. Decreased activity of the transport chain has been observed in haploid mutants for the gene encoding Trx2 [68]. A possibility of therapeutic interference could be the use of TrxR2 inhibitors, expected to modify the redox state and thus the interactions of Trx 2 with its related binding partners within the electron transport chain. 


\section{Lipid metabolism}

Trx2 interacted non-covalently with subunit alpha of the trifunctional protein/enzyme TFP. TFP is an octameric complex composed of four $\alpha$-subunits (HADHA), each composed of a long-chain enoyl-CoA hydratase and a long-chain L-3-hydroxyacyl-CoA dehydrogenase domain and four $\beta$-subunits (HADHB) encoding a long-chain 3-ketoacyl-CoA thiolase domain [151]. The enzyme catalyzes the last three steps of the of long-chain fatty acids $\beta$ oxidation. Defects in TFP may result in hepatic steatosis and insulin resistance [152]. So far there has not been any report correlating thioredoxin proteins to TFP. Regulation of fatty acid biosynthesis has been described for Txnip not via thioredoxin but a specific regulatory microRNA (miR-33a), affecting HADHB activity [153].

Trx2 interacted covalently with mitochondrial acetyl-coenzyme A synthetase 2-like (ACSS1) that converts acetate to acetyl-CoA to be oxidized via the tricarboxylic cycle to produce ATP and $\mathrm{CO}_{2}$. In view of its similarity to ACSL1, ACSS1 is likely to be involved in energy homeostasis and in maintaining normal body temperature during fasting. Deacetylation of ACSS1 by SIRT3 activates the acetyl-CoA synthetase activity of ACSS1 [154]. The interaction with Trx 2 reported here raises another potential level of regulation.

\section{Amino acid metabolism}

The non-covalent interaction of Trx 2 with the $\beta$ chain of mitochondrial methylcrotonoyl-CoA carboxylase (MCCC2), potentially links the thioredoxin system to amino acid metabolism. MCCC2 is the carboxyltransferase subunit of the biotin requiring mitochondrial enzyme 3methylcrotonyl-CoA carboxylase, that is involved in the catabolism of leucine and isovaleric acid. Deficiency of the holoenzyme leads to an autosomal inherited disease that has a variable phenotype ranging from asymptomatic to death in infancy from neurological disorders [155] [156]. Analysis of the transcriptome of a deficient human skin fibroblast cell line revealed that its mitochondria were dysfunctional (e.g. downregulation of transcripts concerning respiratory complex proteins) leading to oxidative stress [156]. It were the Trx 1 transcripts, however, that were upregulated in that study and not the Trx2 ones [156].

Trx 2 reacted covalently with cytosolic 10-formyltetrahydrofolate dehydrogenase (ALDH1L1) an abundant enzyme that catalyses the reductive (via NADPH) decarboxylation of 10formyltetrahydrofolate to tetrahydrofolate and $\mathrm{CO}_{2}$. Although a mitochondrial form of the enzyme exists (ALDH1L2 with $74 \%$ identity to ALDH1L1 [157]), ALDH1L1 is also considered mitochondrial [27]. Folate participates in one-carbon metabolism and comprises a network of interconnected folate-dependent metabolic pathways that are involved in serine 
and glycine interconversion, homocysteine remethylation to methionine and de novo biosynthesis of purine an thymidylate [158]. It is not known how the reported interaction between ALDH1L1 and Trx2 may affect the activity of either enzyme.

\section{Protein/nucleic acid deglycase DJ-1 and Parkinson's disease}

DJ-1/PARK7 is a $2 \times 20 \mathrm{kDa}$ protein localized in the cytosol, nucleus and mitochondria. Autosomal recessive mutations in the $D J-1$ gene causing loss of function, lead to an early start of Parkinson's disease [159]. In this work, Trx2 was able to interact directly with DJ-1. As was the case for human Trx1, it is likely that mitochondrial Trx 2 will be able to reduce Cys ${ }^{53}$ of DJ-1 [24, 160]. While the particular residue may help the dimerisation of DJ-1, the redox state of Cys ${ }^{106}$ that is responsible for the delivery of the antioxidant effects of DJ-1, is affected by peroxiredoxin 2 [160] herein, another interactor of Trx 2 . In an epidemiological study, Parkinson's development after exposure to pesticides was related to defects in Complex I [161]. In this work, Trx 2 interacted with four components of the Complex I. Another potential Trx2 interactor, lactate dehydrogenase $b$ was down regulated in midbrain-derived dopaminergic neuronal cells when exposed to 1-methyl-4-phenyl-1, 2, 3, 6tetrahydropyridine (MPTP) known to promote a Parkinson's phenotype [162]. A 16-year-old adolescent with infantile-onset neurodegenerative disorder had an homozygous stop mutation in the gene encoding Trx 2 , demonstrating the importance of the protein for neuronal integrity [163]. Taken together these observations provide evidence that $\operatorname{Trx} 2$ participates in protein networks with neuroprotective roles.

\section{Prospects}

This work aimed at the identification of mainly strong non-covalent and covalent interactions of Trx 2 in the context of the mitochondrion. Novel partners were identified and thus increased the spectrum of putative functions for Trx2. The number of interactor species (and concomitant functions) is expected to increase even more with the use of more sensitive detection methods that allow for better resolution and more certain identification of protein species (e.g. Orbitrap LC-MS). Equally relevant are the weaker non-covalent interactions that could have been detected by $\mathrm{Y} 2 \mathrm{H}$ screens but here gave only three novel interactors. It is obvious that the "weak" interactome of Trx2 was by no means properly explored. Use of immobilized Trx2, interaction with tissue lysates and elutions by increasing ionic strengths, is likely to reveal more interactions, some of them already known (e.g. ASK1, Txnip) but not detected within the context of this work. Finally, in vitro and in vivo validation of all these 
putative interactors is expected to clarify the effective functional interactome of $\operatorname{Trx} 2$ and perhaps provide fine points of therapeutic interference.

\section{Acknowledgements}

This investigation was supported by grants from the Greek General Secretariat of Research and Technology in collaboration with the European Union (program Enter, 01EP104). 


\section{REFERENCES}

1. Miller, C. G., Holmgren, A., Arner, E. S. J. \& Schmidt, E. E. (2018) NADPH-dependent and independent disulfide reductase systems, Free radical biology \& medicine. 127, 248-261.

2. Laurent, T. C., Moore, E. C. \& Reichard, P. (1964) Enzymatic Synthesis of Deoxyribonucleotides. Iv. Isolation and Characterization of Thioredoxin, the Hydrogen Donor from Escherichia Coli $\mathrm{B}$, The Journal of biological chemistry. 239, 3436-44.

3. Holmgren, A. (1976) Hydrogen donor system for Escherichia coli ribonucleoside-diphosphate reductase dependent upon glutathione, Proceedings of the National Academy of Sciences of the United States of America. 73, 2275-9.

4. Yin, F., Sancheti, H. \& Cadenas, E. (2012) Mitochondrial thiols in the regulation of cell death pathways, Antioxid Redox Signal. 17, 1714-27.

5. Couturier, J., Vignols, F., Jacquot, J. P. \& Rouhier, N. (2012) Glutathione- and glutaredoxindependent reduction of methionine sulfoxide reductase A, FEBS letters. 586, 3894-9.

6. Lundstrom-Ljung, J., Vlamis-Gardikas, A., Aslund, F. \& Holmgren, A. (1999) Reactivity of glutaredoxins 1, 2 and 3 from Escherichia coli and protein disulfide isomerase towards glutathionylmixed disulfides in ribonuclease A, FEBS letters. 443, 85-8.

7. Mark, D. F. \& Richardson, C. C. (1976) Escherichia coli thioredoxin: a subunit of bacteriophage T7 DNA polymerase, Proceedings of the National Academy of Sciences of the United States of America. 73, 780-4.

8. Lu, J. \& Holmgren, A. (2012) Thioredoxin system in cell death progression, Antioxidants \& redox signaling. 17, 1738-47.

9. Saxena, G., Chen, J. \& Shalev, A. (2010) Intracellular shuttling and mitochondrial function of thioredoxin-interacting protein, The Journal of biological chemistry. 285, 3997-4005.

10. Zhang, R., Al-Lamki, R., Bai, L., Streb, J. W., Miano, J. M., Bradley, J. \& Min, W. (2004)

Thioredoxin-2 inhibits mitochondria-located ASK1-mediated apoptosis in a JNK-independent manner, Circulation research. 94, 1483-91.

11. Dammeyer, P., Damdimopoulos, A. E., Nordman, T., Jimenez, A., Miranda-Vizuete, A. \& Arner, E. S. (2008) Induction of cell membrane protrusions by the $\mathrm{N}$-terminal glutaredoxin domain of a rare splice variant of human thioredoxin reductase 1, The Journal of biological chemistry. 283, 2814-21. 12. Vlamis-Gardikas, A. \& Holmgren, A. (2002) Thioredoxin and glutaredoxin isoforms, Methods in enzymology. 347, 286-96.

13. Spyrou, G., Enmark, E., Miranda-Vizuete, A. \& Gustafsson, J. (1997) Cloning and expression of a novel mammalian thioredoxin, The Journal of biological chemistry. 272, 2936-41.

14. Halvey, P. J., Watson, W. H., Hansen, J. M., Go, Y. M., Samali, A. \& Jones, D. P. (2005)

Compartmental oxidation of thiol-disulphide redox couples during epidermal growth factor signalling, The Biochemical journal. 386, 215-9.

15. Hansen, J. M., Zhang, H. \& Jones, D. P. (2006) Mitochondrial thioredoxin-2 has a key role in determining tumor necrosis factor-alpha-induced reactive oxygen species generation, NF-kappaB activation, and apoptosis, Toxicological sciences : an official journal of the Society of Toxicology. 91, 643-50.

16. Zhou, J., Damdimopoulos, A. E., Spyrou, G. \& Brune, B. (2007) Thioredoxin 1 and thioredoxin 2 have opposed regulatory functions on hypoxia-inducible factor-1alpha, The Journal of biological chemistry. 282, 7482-90.

17. Kumar, J. K., Tabor, S. \& Richardson, C. C. (2004) Proteomic analysis of thioredoxin-targeted proteins in Escherichia coli, Proceedings of the National Academy of Sciences of the United States of America. 101, 3759-64.

18. Arts, I. S., Vertommen, D., Baldin, F., Laloux, G. \& Collet, J. F. (2016) Comprehensively Characterizing the Thioredoxin Interactome In Vivo Highlights the Central Role Played by This Ubiquitous Oxidoreductase in Redox Control, Molecular \& cellular proteomics : MCP. 15, 2125-40. 
19. Motohashi, K., Romano, P. G. \& Hisabori, T. (2009) Identification of thioredoxin targeted proteins using thioredoxin single cysteine mutant-immobilized resin, Methods in molecular biology. 479, 11731.

20. Sturm, N., Jortzik, E., Mailu, B. M., Koncarevic, S., Deponte, M., Forchhammer, K., Rahlfs, S. \& Becker, K. (2009) Identification of proteins targeted by the thioredoxin superfamily in Plasmodium falciparum, PLoS pathogens. 5, e1000383.

21. Schlosser, S., Leitsch, D. \& Duchene, M. (2013) Entamoeba histolytica: identification of thioredoxin-targeted proteins and analysis of serine acetyltransferase-1 as a prototype example, The Biochemical journal. 451, 277-88.

22. Schutte, L. D., Baumeister, S., Weis, B., Hudemann, C., Hanschmann, E. M. \& Lillig, C. H. (2013) Identification of potential protein dithiol-disulfide substrates of mammalian Grx2, Biochimica et biophysica acta. 1830, 4999-5005.

23. Wu, C., Parrott, A. M., Liu, T., Jain, M. R., Yang, Y., Sadoshima, J. \& Li, H. (2011) Distinction of thioredoxin transnitrosylation and denitrosylation target proteins by the ICAT quantitative approach, Journal of proteomics. 74, 2498-509.

24. Fu, C., Wu, C., Liu, T., Ago, T., Zhai, P., Sadoshima, J. \& Li, H. (2009) Elucidation of thioredoxin target protein networks in mouse, Molecular \& cellular proteomics : MCP. 8, 1674-87.

25. Booze, M. L., Hansen, J. M. \& Vitiello, P. F. (2016) A novel mouse model for the identification of thioredoxin-1 protein interactions, Free radical biology \& medicine. 99, 533-543.

26. Chatr-Aryamontri, A., Oughtred, R., Boucher, L., Rust, J., Chang, C., Kolas, N. K., O'Donnell, L., Oster, S., Theesfeld, C., Sellam, A., Stark, C., Breitkreutz, B. J., Dolinski, K. \& Tyers, M. (2017) The BioGRID interaction database: 2017 update, Nucleic acids research. 45, D369-D379.

27. Calvo, S. E., Clauser, K. R. \& Mootha, V. K. (2016) MitoCarta2.0: an updated inventory of mammalian mitochondrial proteins, Nucleic acids research. 44, D1251-7.

28. Diokmetzidou, A., Tsikitis, M., Nikouli, S., Kloukina, I., Tsoupri, E., Papathanasiou, S., Psarras, S., Mavroidis, M. \& Capetanaki, Y. (2016) Strategies to Study Desmin in Cardiac Muscle and Culture Systems, Methods in enzymology. 568, 427-59.

29. Bensadoun, A. \& Weinstein, D. (1976) Assay of proteins in the presence of interfering materials, Analytical biochemistry. 70, 241-50.

30. Shannon, P., Markiel, A., Ozier, O., Baliga, N. S., Wang, J. T., Ramage, D., Amin, N., Schwikowski, B. \& Ideker, T. (2003) Cytoscape: a software environment for integrated models of biomolecular interaction networks, Genome research. 13, 2498-504.

31. Hamosh, A., Scott, A. F., Amberger, J. S., Bocchini, C. A. \& McKusick, V. A. (2005) Online Mendelian Inheritance in Man (OMIM), a knowledgebase of human genes and genetic disorders, Nucleic acids research. 33, D514-7.

32. Jiao, X., Sherman, B. T., Huang da, W., Stephens, R., Baseler, M. W., Lane, H. C. \& Lempicki, R. A. (2012) DAVID-WS: a stateful web service to facilitate gene/protein list analysis, Bioinformatics. 28, 1805-6.

33. Bindea, G., Mlecnik, B., Hackl, H., Charoentong, P., Tosolini, M., Kirilovsky, A., Fridman, W. H., Pages, F., Trajanoski, Z. \& Galon, J. (2009) ClueGO: a Cytoscape plug-in to decipher functionally grouped gene ontology and pathway annotation networks, Bioinformatics. 25, 1091-3.

34. Chasapis, C. T., Andreini, C., Georgiopolou, A. K., Stefanidou, M. E. \& Vlamis-Gardikas, A. (2017) Identification of the zinc, copper and cadmium metalloproteome of the protozoon Tetrahymena thermophila by systematic bioinformatics, Archives of microbiology. 199, 1141-1149.

35. Damdimopoulos, A. E., Miranda-Vizuete, A., Pelto-Huikko, M., Gustafsson, J. A. \& Spyrou, G. (2002) Human mitochondrial thioredoxin. Involvement in mitochondrial membrane potential and cell death, The Journal of biological chemistry. 277, 33249-57.

36. Goh, K. I., Cusick, M. E., Valle, D., Childs, B., Vidal, M. \& Barabasi, A. L. (2007) The human disease network, Proceedings of the National Academy of Sciences of the United States of America. 104, 8685-90. 
37. Singha, N. C., Vlamis-Gardikas, A. \& Holmgren, A. (2003) Real-time kinetics of the interaction between the two subunits, Escherichia coli thioredoxin and gene 5 protein of phage T7 DNA polymerase, The Journal of biological chemistry. 278, 21421-8.

38. Bjornstedt, M., Kumar, S. \& Holmgren, A. (1995) Selenite and selenodiglutathione: reactions with thioredoxin systems, Methods in enzymology. 252, 209-19.

39. Berndt, C., Schwenn, J. D. \& Lillig, C. H. (2015) The specificity of thioredoxins and glutaredoxins is determined by electrostatic and geometric complementarity, Chemical science. 6, 7049-7058. 40. Perez-Jimenez, R., Li, J., Kosuri, P., Sanchez-Romero, I., Wiita, A. P., Rodriguez-Larrea, D., Chueca, A., Holmgren, A., Miranda-Vizuete, A., Becker, K., Cho, S. H., Beckwith, J., Gelhaye, E., Jacquot, J. P., Gaucher, E. A., Sanchez-Ruiz, J. M., Berne, B. J. \& Fernandez, J. M. (2009) Diversity of chemical mechanisms in thioredoxin catalysis revealed by single-molecule force spectroscopy, Nature structural \& molecular biology. 16, 890-6.

41. Ott, C., Dorsch, E., Fraunholz, M., Straub, S. \& Kozjak-Pavlovic, V. (2015) Detailed analysis of the human mitochondrial contact site complex indicate a hierarchy of subunits, PloS one. 10, e0120213. 42. Kennedy, H., Haack, T. B., Hartill, V., Matakovic, L., Baumgartner, E. R., Potter, H., Mackay, R., Alston, C. L., O'Sullivan, S., McFarland, R., Connolly, G., Gannon, C., King, R., Mead, S., Crozier, I., Chan, W., Florkowski, C. M., Sage, M., Hofken, T., Alhaddad, B., Kremer, L. S., Kopajtich, R., Feichtinger, R. G., Sperl, W., Rodenburg, R. J., Minet, J. C., Dobbie, A., Strom, T. M., Meitinger, T., George, P. M., Johnson, C. A., Taylor, R. W., Prokisch, H., Doudney, K. \& Mayr, J. A. (2016) Sudden Cardiac Death Due to Deficiency of the Mitochondrial Inorganic Pyrophosphatase PPA2, American journal of human genetics. 99, 674-682.

43. Berndt, C., Lillig, C. H. \& Holmgren, A. (2007) Thiol-based mechanisms of the thioredoxin and glutaredoxin systems: implications for diseases in the cardiovascular system, American journal of physiology Heart and circulatory physiology. 292, H1227-36.

44. Li, H., Xu, C., Li, Q., Gao, X., Sugano, E., Tomita, H., Yang, L. \& Shi, S. (2017) Thioredoxin 2 Offers Protection against Mitochondrial Oxidative Stress in H9c2 Cells and against Myocardial Hypertrophy Induced by Hyperglycemia, International journal of molecular sciences. 18.

45. Chen, C., Chen, H., Zhou, H. J., Ji, W. \& Min, W. (2017) Mechanistic Role of Thioredoxin 2 in Heart Failure, Advances in experimental medicine and biology. 982, 265-276.

46. Conrad, M., Jakupoglu, C., Moreno, S. G., Lippl, S., Banjac, A., Schneider, M., Beck, H., Hatzopoulos, A. K., Just, U., Sinowatz, F., Schmahl, W., Chien, K. R., Wurst, W., Bornkamm, G. W. \& Brielmeier, M. (2004) Essential role for mitochondrial thioredoxin reductase in hematopoiesis, heart development, and heart function, Molecular and cellular biology. 24, 9414-23.

47. Lill, R., Hoffmann, B., Molik, S., Pierik, A. J., Rietzschel, N., Stehling, O., Uzarska, M. A., Webert, H., Wilbrecht, C. \& Muhlenhoff, U. (2012) The role of mitochondria in cellular iron-sulfur protein biogenesis and iron metabolism, Biochimica et biophysica acta. 1823, 1491-508.

48. Shan, Y. \& Cortopassi, G. (2016) Mitochondrial Hspa9/Mortalin regulates erythroid differentiation via iron-sulfur cluster assembly, Mitochondrion. 26, 94-103.

49. Chen, T. H., Kambal, A., Krysiak, K., Walshauser, M. A., Raju, G., Tibbitts, J. F. \& Walter, M. J. (2011) Knockdown of Hspa9, a del(5q31.2) gene, results in a decrease in hematopoietic progenitors in mice, Blood. 117, 1530-9.

50. Guo, R., Zong, S., Wu, M., Gu, J. \& Yang, M. (2017) Architecture of Human Mitochondrial Respiratory Megacomplex I2III2IV2, Cell. 170, 1247-1257 e12.

51. Song, J. Y., Cha, J., Lee, J. \& Roe, J. H. (2006) Glutathione reductase and a mitochondrial thioredoxin play overlapping roles in maintaining iron-sulfur enzymes in fission yeast, Eukaryotic cell. 5, 1857-65.

52. Ding, H., Harrison, K. \& Lu, J. (2005) Thioredoxin reductase system mediates iron binding in IscA and iron delivery for the iron-sulfur cluster assembly in IscU, The Journal of biological chemistry. 280, 30432-7.

53. Sawicki, K. T., Chang, H. C. \& Ardehali, H. (2015) Role of heme in cardiovascular physiology and disease, Journal of the American Heart Association. 4, e001138. 
54. Thomas, C., Mackey, M. M., Diaz, A. A. \& Cox, D. P. (2009) Hydroxyl radical is produced via the Fenton reaction in submitochondrial particles under oxidative stress: implications for diseases associated with iron accumulation, Redox report : communications in free radical research. 14, 102-8. 55. Cox, A. G., Winterbourn, C. C. \& Hampton, M. B. (2009) Mitochondrial peroxiredoxin involvement in antioxidant defence and redox signalling, The Biochemical journal. 425, 313-25.

56. Nonn, L., Berggren, M. \& Powis, G. (2003) Increased expression of mitochondrial peroxiredoxin-3 (thioredoxin peroxidase-2) protects cancer cells against hypoxia and drug-induced hydrogen peroxide-dependent apoptosis, Molecular cancer research : MCR. 1, 682-9.

57. Matsushima, S., Ide, T., Yamato, M., Matsusaka, H., Hattori, F., Ikeuchi, M., Kubota, T., Sunagawa, K., Hasegawa, Y., Kurihara, T., Oikawa, S., Kinugawa, S. \& Tsutsui, H. (2006) Overexpression of mitochondrial peroxiredoxin-3 prevents left ventricular remodeling and failure after myocardial infarction in mice, Circulation. 113, 1779-86.

58. Watabe, S., Hiroi, T., Yamamoto, Y., Fujioka, Y., Hasegawa, H., Yago, N. \& Takahashi, S. Y. (1997) $\mathrm{SP}-22$ is a thioredoxin-dependent peroxide reductase in mitochondria, European journal of biochemistry. 249, 52-60.

59. Hanschmann, E. M., Lonn, M. E., Schutte, L. D., Funke, M., Godoy, J. R., Eitner, S., Hudemann, C. \& Lillig, C. H. (2010) Both thioredoxin 2 and glutaredoxin 2 contribute to the reduction of the mitochondrial 2-Cys peroxiredoxin Prx3, The Journal of biological chemistry. 285, 40699-705. 60. Zhang, H., Go, Y. M. \& Jones, D. P. (2007) Mitochondrial thioredoxin-2/peroxiredoxin-3 system functions in parallel with mitochondrial GSH system in protection against oxidative stress, Archives of biochemistry and biophysics. 465, 119-26.

61. Stanley, B. A., Sivakumaran, V., Shi, S., McDonald, I., Lloyd, D., Watson, W. H., Aon, M. A. \& Paolocci, N. (2011) Thioredoxin reductase-2 is essential for keeping low levels of $\mathrm{H}(2) \mathrm{O}(2)$ emission from isolated heart mitochondria, The Journal of biological chemistry. 286, 33669-77.

62. Forred, B. J., Daugaard, D. R., Titus, B. K., Wood, R. R., Floen, M. J., Booze, M. L. \& Vitiello, P. F. (2017) Detoxification of Mitochondrial Oxidants and Apoptotic Signaling Are Facilitated by Thioredoxin-2 and Peroxiredoxin-3 during Hyperoxic Injury, PloS one. 12, e0168777.

63. Makkar, R. S., Contreras, M. A., Paintlia, A. S., Smith, B. T., Haq, E. \& Singh, I. (2006) Molecular organization of peroxisomal enzymes: protein-protein interactions in the membrane and in the matrix, Archives of biochemistry and biophysics. 451, 128-40.

64. Burk, K. \& Pasterkamp, R. J. (2019) Disrupted neuronal trafficking in amyotrophic lateral sclerosis, Acta neuropathologica.

65. Valentine, J. S., Doucette, P. A. \& Zittin Potter, S. (2005) Copper-zinc superoxide dismutase and amyotrophic lateral sclerosis, Annual review of biochemistry. 74, 563-93.

66. Chattopadhyay, M. \& Valentine, J. S. (2009) Aggregation of copper-zinc superoxide dismutase in familial and sporadic ALS, Antioxid Redox Signal. 11, 1603-14.

67. Doucette, P. A., Whitson, L. J., Cao, X., Schirf, V., Demeler, B., Valentine, J. S., Hansen, J. C. \& Hart, P. J. (2004) Dissociation of human copper-zinc superoxide dismutase dimers using chaotrope and reductant. Insights into the molecular basis for dimer stability, The Journal of biological chemistry. 279, 54558-66.

68. Perez, V. I., Lew, C. M., Cortez, L. A., Webb, C. R., Rodriguez, M., Liu, Y., Qi, W., Li, Y., Chaudhuri, A., Van Remmen, H., Richardson, A. \& Ikeno, Y. (2008) Thioredoxin 2 haploinsufficiency in mice results in impaired mitochondrial function and increased oxidative stress, Free radical biology \& medicine. 44, 882-92.

69. Deza-Ponzio, R., Herrera, M. L., Bellini, M. J., Virgolini, M. B. \& Herenu, C. B. (2018) Aldehyde dehydrogenase 2 in the spotlight: The link between mitochondria and neurodegeneration, Neurotoxicology. 68, 19-24.

70. Seitz, H. K. \& Meier, P. (2007) The role of acetaldehyde in upper digestive tract cancer in alcoholics, Translational research : the journal of laboratory and clinical medicine. 149, 293-7. 71. Chen, C. H., Ferreira, J. C., Gross, E. R. \& Mochly-Rosen, D. (2014) Targeting aldehyde dehydrogenase 2: new therapeutic opportunities, Physiological reviews. 94, 1-34. 
72. Goldstein, D. S., Sullivan, P., Holmes, C., Miller, G. W., Alter, S., Strong, R., Mash, D. C., Kopin, I. J. \& Sharabi, Y. (2013) Determinants of buildup of the toxic dopamine metabolite DOPAL in Parkinson's disease, Journal of neurochemistry. 126, 591-603.

73. Oelze, M., Knorr, M., Schell, R., Kamuf, J., Pautz, A., Art, J., Wenzel, P., Munzel, T., Kleinert, H. \& Daiber, A. (2011) Regulation of human mitochondrial aldehyde dehydrogenase (ALDH-2) activity by electrophiles in vitro, The Journal of biological chemistry. 286, 8893-900.

74. Miura, T., Nishinaka, T. \& Terada, T. (2008) Different functions between human monomeric carbonyl reductase 3 and carbonyl reductase 1, Molecular and cellular biochemistry. 315, 113-21.

75. Shibata, T., Yamada, T., Ishii, T., Kumazawa, S., Nakamura, H., Masutani, H., Yodoi, J. \& Uchida, K. (2003) Thioredoxin as a molecular target of cyclopentenone prostaglandins, The Journal of biological chemistry. 278, 26046-54.

76. Ban, N., Beckmann, R., Cate, J. H., Dinman, J. D., Dragon, F., Ellis, S. R., Lafontaine, D. L., Lindahl, L., Liljas, A., Lipton, J. M., McAlear, M. A., Moore, P. B., Noller, H. F., Ortega, J., Panse, V. G., Ramakrishnan, V., Spahn, C. M., Steitz, T. A., Tchorzewski, M., Tollervey, D., Warren, A. J., Williamson, J. R., Wilson, D., Yonath, A. \& Yusupov, M. (2014) A new system for naming ribosomal proteins, Current opinion in structural biology. 24, 165-9.

77. Baltz, A. G., Munschauer, M., Schwanhausser, B., Vasile, A., Murakawa, Y., Schueler, M., Youngs, N., Penfold-Brown, D., Drew, K., Milek, M., Wyler, E., Bonneau, R., Selbach, M., Dieterich, C. \& Landthaler, M. (2012) The mRNA-bound proteome and its global occupancy profile on protein-coding transcripts, Molecular cell. 46, 674-90.

78. Lunn, C. A. \& Pigiet, V. P. (1982) Localization of thioredoxin from Escherichia coli in an osmotically sensitive compartment, The Journal of biological chemistry. 257, 11424-30.

79. Richarme, G. (1998) Protein-disulfide isomerase activity of elongation factor EF-Tu, Biochemical and biophysical research communications. 252, 156-61.

80. Yutthanasirikul, R., Nagano, T., Jimbo, H., Hihara, Y., Kanamori, T., Ueda, T., Haruyama, T., Konno, H., Yoshida, K., Hisabori, T. \& Nishiyama, Y. (2016) Oxidation of a Cysteine Residue in Elongation Factor EF-Tu Reversibly Inhibits Translation in the Cyanobacterium Synechocystis sp. PCC 6803, The Journal of biological chemistry. 291, 5860-70.

81. Viitanen, P. V., Lorimer, G. H., Seetharam, R., Gupta, R. S., Oppenheim, J., Thomas, J. O. \& Cowan, N. J. (1992) Mammalian mitochondrial chaperonin 60 functions as a single toroidal ring, The Journal of biological chemistry. 267, 695-8.

82. Nielsen, K. L. \& Cowan, N. J. (1998) A single ring is sufficient for productive chaperonin-mediated folding in vivo, Molecular cell. 2, 93-9.

83. McMullin, T. W. \& Hallberg, R. L. (1988) A highly evolutionarily conserved mitochondrial protein is structurally related to the protein encoded by the Escherichia coli groEL gene, Molecular and cellular biology. 8, 371-80.

84. Lubben, T. H., Gatenby, A. A., Donaldson, G. K., Lorimer, G. H. \& Viitanen, P. V. (1990) Identification of a groES-like chaperonin in mitochondria that facilitates protein folding, Proceedings of the National Academy of Sciences of the United States of America. 87, 7683-7.

85. Bottinger, L., Oeljeklaus, S., Guiard, B., Rospert, S., Warscheid, B. \& Becker, T. (2015)

Mitochondrial heat shock protein (Hsp) 70 and Hsp10 cooperate in the formation of Hsp60 complexes, The Journal of biological chemistry. 290, 11611-22.

86. Jankevicius, G., Hassler, M., Golia, B., Rybin, V., Zacharias, M., Timinszky, G. \& Ladurner, A. G. (2013) A family of macrodomain proteins reverses cellular mono-ADP-ribosylation, Nature structural \& molecular biology. 20, 508-14.

87. Rack, J. G., Perina, D. \& Ahel, I. (2016) Macrodomains: Structure, Function, Evolution, and Catalytic Activities, Annual review of biochemistry. 85, 431-54.

88. Agnew, T., Munnur, D., Crawford, K., Palazzo, L., Mikoc, A. \& Ahel, I. (2018) MacroD1 Is a Promiscuous ADP-Ribosyl Hydrolase Localized to Mitochondria, Frontiers in microbiology. 9, 20.

89. Han, W. D., Zhao, Y. L., Meng, Y. G., Zang, L., Wu, Z. Q., Li, Q., Si, Y. L., Huang, K., Ba, J. M., Morinaga, H., Nomura, M. \& Mu, Y. M. (2007) Estrogenically regulated LRP16 interacts with estrogen 
receptor alpha and enhances the receptor's transcriptional activity, Endocrine-related cancer. 14, 741-53.

90. Psarra, A. M., Hermann, S., Panayotou, G. \& Spyrou, G. (2009) Interaction of mitochondrial thioredoxin with glucocorticoid receptor and NF-kappaB modulates glucocorticoid receptor and NFkappaB signalling in HEK-293 cells, The Biochemical journal. 422, 521-31.

91. Rao, A. K., Ziegler, Y. S., McLeod, I. X., Yates, J. R. \& Nardulli, A. M. (2009) Thioredoxin and thioredoxin reductase influence estrogen receptor alpha-mediated gene expression in human breast cancer cells, Journal of molecular endocrinology. 43, 251-61.

92. Orosz, F., Olah, J. \& Ovadi, J. (2006) Triosephosphate isomerase deficiency: facts and doubts, IUBMB life. 58, 703-15.

93. Michelet, L., Zaffagnini, M., Massot, V., Keryer, E., Vanacker, H., Miginiac-Maslow, M., IssakidisBourguet, E. \& Lemaire, S. D. (2006) Thioredoxins, glutaredoxins, and glutathionylation: new crosstalks to explore, Photosynthesis research. 89, 225-45.

94. Liaud, M. F., Lichtle, C., Apt, K., Martin, W. \& Cerff, R. (2000) Compartment-specific isoforms of TPI and GAPDH are imported into diatom mitochondria as a fusion protein: evidence in favor of a mitochondrial origin of the eukaryotic glycolytic pathway, Molecular biology and evolution. 17, 21323.

95. Orosz, F., Olah, J. \& Ovadi, J. (2009) Triosephosphate isomerase deficiency: new insights into an enigmatic disease, Biochimica et biophysica acta. 1792, 1168-74.

96. Kawazu, S., Takemae, H., Komaki-Yasuda, K. \& Kano, S. (2010) Target proteins of the cytosolic thioredoxin in Plasmodium falciparum, Parasitology international. 59, 298-302.

97. Bedhomme, M., Adamo, M., Marchand, C. H., Couturier, J., Rouhier, N., Lemaire, S. D., Zaffagnini, M. \& Trost, P. (2012) Glutathionylation of cytosolic glyceraldehyde-3-phosphate dehydrogenase from the model plant Arabidopsis thaliana is reversed by both glutaredoxins and thioredoxins in vitro, The Biochemical journal. 445, 337-47.

98. Chakravarti, R. \& Stuehr, D. J. (2012) Thioredoxin-1 regulates cellular heme insertion by controlling S-nitrosation of glyceraldehyde-3-phosphate dehydrogenase, The Journal of biological chemistry. 287, 16179-86.

99. Ju, Y., Wu, L. \& Yang, G. (2016) Thioredoxin 1 regulation of protein S-desulfhydration, Biochemistry and biophysics reports. 5, 27-34.

100. Yan, H., Lou, M. F., Fernando, M. R. \& Harding, J. J. (2006) Thioredoxin, thioredoxin reductase, and alpha-crystallin revive inactivated glyceraldehyde 3-phosphate dehydrogenase in human aged and cataract lens extracts, Molecular vision. 12, 1153-9.

101. Gupte, S. A., Rupawalla, T., Mohazzab, H. K. \& Wolin, M. S. (1999) Regulation of NO-elicited pulmonary artery relaxation and guanylate cyclase activation by NADH oxidase and SOD, The American journal of physiology. 276, H1535-42.

102. Lee, Y. J., Kang, I. J., Bunger, R. \& Kang, Y. H. (2004) Enhanced survival effect of pyruvate correlates MAPK and NF-kappaB activation in hydrogen peroxide-treated human endothelial cells, Journal of applied physiology. 96, 793-801; discussion 792.

103. Ali, M. A., Yasui, F., Matsugo, S. \& Konishi, T. (2000) The lactate-dependent enhancement of hydroxyl radical generation by the Fenton reaction, Free radical research. 32, 429-38.

104. Leong, P. K. \& Ko, K. M. (2015) Schisandrin B induces an Nrf2-mediated thioredoxin expression and suppresses the activation of inflammasome in vitro and in vivo, BioFactors. 41, 314-23.

105. Milovanova, T. N., Bhopale, V. M., Sorokina, E. M., Moore, J. S., Hunt, T. K., Hauer-Jensen, M., Velazquez, O. C. \& Thom, S. R. (2008) Lactate stimulates vasculogenic stem cells via the thioredoxin system and engages an autocrine activation loop involving hypoxia-inducible factor 1 , Molecular and cellular biology. 28, 6248-61.

106. Lugokenski, T. H., Muller, L. G., Taube, P. S., Rocha, J. B. \& Pereira, M. E. (2011) Inhibitory effect of ebselen on lactate dehydrogenase activity from mammals: a comparative study with diphenyl diselenide and diphenyl ditelluride, Drug and chemical toxicology. 34, 66-76. 
107. Ciszak, E. M., Korotchkina, L. G., Dominiak, P. M., Sidhu, S. \& Patel, M. S. (2003) Structural basis for flip-flop action of thiamin pyrophosphate-dependent enzymes revealed by human pyruvate dehydrogenase, The Journal of biological chemistry. 278, 21240-6.

108. Kato, M., Wynn, R. M., Chuang, J. L., Tso, S. C., Machius, M., Li, J. \& Chuang, D. T. (2008) Structural basis for inactivation of the human pyruvate dehydrogenase complex by phosphorylation: role of disordered phosphorylation loops, Structure. 16, 1849-59.

109. Patel, M. S. \& Roche, T. E. (1990) Molecular biology and biochemistry of pyruvate dehydrogenase complexes, FASEB journal : official publication of the Federation of American Societies for Experimental Biology. 4, 3224-33.

110. Balakrishnan, A., Nemeria, N. S., Chakraborty, S., Kakalis, L. \& Jordan, F. (2012) Determination of pre-steady-state rate constants on the Escherichia coli pyruvate dehydrogenase complex reveals that loop movement controls the rate-limiting step, Journal of the American Chemical Society. 134, 18644-55.

111. Holmgren, A. (1979) Thioredoxin catalyzes the reduction of insulin disulfides by dithiothreitol and dihydrolipoamide, The Journal of biological chemistry. 254, 9627-32.

112. Feeney, M. A., Veeravalli, K., Boyd, D., Gon, S., Faulkner, M. J., Georgiou, G. \& Beckwith, J. (2011) Repurposing lipoic acid changes electron flow in two important metabolic pathways of Escherichia coli, Proceedings of the National Academy of Sciences of the United States of America. 108, 7991-6.

113. Jordan, F., Arjunan, P., Kale, S., Nemeria, N. S. \& Furey, W. (2009) Multiple roles of mobile active center loops in the E1 component of the Escherichia coli pyruvate dehydrogenase complex Linkage of protein dynamics to catalysis, Journal of molecular catalysis B, Enzymatic. 61, 14-22. 114. Fisher-Wellman, K. H., Lin, C. T., Ryan, T. E., Reese, L. R., Gilliam, L. A., Cathey, B. L., Lark, D. S., Smith, C. D., Muoio, D. M. \& Neufer, P. D. (2015) Pyruvate dehydrogenase complex and nicotinamide nucleotide transhydrogenase constitute an energy-consuming redox circuit, The Biochemical journal. 467, 271-80.

115. Shumar, S. A., Kerr, E. W., Geldenhuys, W. J., Montgomery, G. E., Fagone, P., Thirawatananond, P., Saavedra, H., Gabelli, S. B. \& Leonardi, R. (2018) Nudt19 is a renal CoA diphosphohydrolase with biochemical and regulatory properties that are distinct from the hepatic Nudt7 isoform, The Journal of biological chemistry. 293, 4134-4148.

116. Kim, J. H., Fuzery, A. K., Tonelli, M., Ta, D. T., Westler, W. M., Vickery, L. E. \& Markley, J. L. (2009) Structure and dynamics of the iron-sulfur cluster assembly scaffold protein IscU and its interaction with the cochaperone HscB, Biochemistry. 48, 6062-71.

117. Kaptain, S., Downey, W. E., Tang, C., Philpott, C., Haile, D., Orloff, D. G., Harford, J. B., Rouault, T. A. \& Klausner, R. D. (1991) A regulated RNA binding protein also possesses aconitase activity, Proceedings of the National Academy of Sciences of the United States of America. 88, 10109-13. 118. Moeder, W., Del Pozo, O., Navarre, D. A., Martin, G. B. \& Klessig, D. F. (2007) Aconitase plays a role in regulating resistance to oxidative stress and cell death in Arabidopsis and Nicotiana benthamiana, Plant molecular biology. 63, 273-87.

119. Tang, Y. \& Guest, J. R. (1999) Direct evidence for mRNA binding and post-transcriptional regulation by Escherichia coli aconitases, Microbiology. 145 ( Pt 11), 3069-79.

120. Metodiev, M. D., Gerber, S., Hubert, L., Delahodde, A., Chretien, D., Gerard, X., Amati-Bonneau, P., Giacomotto, M. C., Boddaert, N., Kaminska, A., Desguerre, I., Amiel, J., Rio, M., Kaplan, J., Munnich, A., Rotig, A., Rozet, J. M. \& Besmond, C. (2014) Mutations in the tricarboxylic acid cycle enzyme, aconitase 2 , cause either isolated or syndromic optic neuropathy with encephalopathy and cerebellar atrophy, Journal of medical genetics. 51, 834-8.

121. Talib, J. \& Davies, M. J. (2016) Exposure of aconitase to smoking-related oxidants results in iron loss and increased iron response protein-1 activity: potential mechanisms for iron accumulation in human arterial cells, Journal of biological inorganic chemistry : JBIC : a publication of the Society of Biological Inorganic Chemistry. 21, 305-17. 
122. White, K., Kim, M. J., Han, C., Park, H. J., Ding, D., Boyd, K., Walker, L., Linser, P., Meneses, Z., Slade, C., Hirst, J., Santostefano, K., Terada, N., Miyakawa, T., Tanokura, M., Salvi, R. \& Someya, S. (2018) Loss of IDH2 Accelerates Age-related Hearing Loss in Male Mice, Scientific reports. 8, 5039. 123. Xu, Y., Liu, L., Nakamura, A., Someya, S., Miyakawa, T. \& Tanokura, M. (2017) Studies on the regulatory mechanism of isocitrate dehydrogenase 2 using acetylation mimics, Scientific reports. 7, 9785.

124. Ma, T., Peng, Y., Huang, W., Liu, Y. \& Ding, J. (2017) The beta and gamma subunits play distinct functional roles in the alpha2betagamma heterotetramer of human NAD-dependent isocitrate dehydrogenase, Scientific reports. 7, 41882.

125. Izquierdo-Garcia, J. L., Viswanath, P., Eriksson, P., Cai, L., Radoul, M., Chaumeil, M. M., Blough, M., Luchman, H. A., Weiss, S., Cairncross, J. G., Phillips, J. J., Pieper, R. O. \& Ronen, S. M. (2015) IDH1 Mutation Induces Reprogramming of Pyruvate Metabolism, Cancer research. 75, 2999-3009.

126. Vartak, R. S., Semwal, M. K. \& Bai, Y. (2014) An update on complex I assembly: the assembly of players, Journal of bioenergetics and biomembranes. 46, 323-8.

127. Moparthi, V. K. \& Hagerhall, C. (2011) The evolution of respiratory chain complex I from a smaller last common ancestor consisting of 11 protein subunits, Journal of molecular evolution. $\mathbf{7 2 ,}$ 484-97.

128. Andrews, B., Carroll, J., Ding, S., Fearnley, I. M. \& Walker, J. E. (2013) Assembly factors for the membrane arm of human complex I, Proceedings of the National Academy of Sciences of the United States of America. 110, 18934-9.

129. Jaokar, T. M., Patil, D. P., Shouche, Y. S., Gaikwad, S. M. \& Suresh, C. G. (2013) Human mitochondrial NDUFS3 protein bearing Leigh syndrome mutation is more prone to aggregation than its wild-type, Biochimie. 95, 2392-403.

130. Yankovskaya, V., Horsefield, R., Tornroth, S., Luna-Chavez, C., Miyoshi, H., Leger, C., Byrne, B., Cecchini, G. \& Iwata, S. (2003) Architecture of succinate dehydrogenase and reactive oxygen species generation, Science. 299, 700-4.

131. Sharma, L. K., Lu, J. \& Bai, Y. (2009) Mitochondrial respiratory complex I: structure, function and implication in human diseases, Current medicinal chemistry. 16, 1266-77.

132. Du, Z., Liu, X., Chen, T., Gao, W., Wu, Z., Hu, Z., Wei, D., Gao, C. \& Li, Q. (2018) Targeting a Sirt5Positive Subpopulation Overcomes Multidrug Resistance in Wild-Type Kras Colorectal Carcinomas, Cell reports. 22, 2677-2689.

133. Crofts, A. R. (2004) The cytochrome bc1 complex: function in the context of structure, Annual review of physiology. 66, 689-733.

134. Hoffman, G. G., Lee, S., Christiano, A. M., Chung-Honet, L. C., Cheng, W., Katchman, S., Uitto, J. \& Greenspan, D. S. (1993) Complete coding sequence, intron/exon organization, and chromosomal location of the gene for the core I protein of human ubiquinol-cytochrome c reductase, The Journal of biological chemistry. 268, 21113-9.

135. Huang, S., Wang, J. \& Cui, Y. (2016) 2,2',4,4'-Tetrabromodiphenyl ether injures cell viability and mitochondrial function of mouse spermatocytes by decreasing mitochondrial proteins Atp $5 \mathrm{~b}$ and Uqcrc1, Environmental toxicology and pharmacology. 46, 301-310.

136. Kunej, T., Wang, Z., Michal, J. J., Daniels, T. F., Magnuson, N. S. \& Jiang, Z. (2007) Functional UQCRC1 polymorphisms affect promoter activity and body lipid accumulation, Obesity. 15, 2896-901. 137. Shang, Y., Zhang, F., Li, D., Li, C., Li, H., Jiang, Y. \& Zhang, D. (2018) Overexpression of UQCRC2 is correlated with tumor progression and poor prognosis in colorectal cancer, Pathology, research and practice.

138. Bai, Y. H., Zhan, Y. B., Yu, B., Wang, W. W., Wang, L., Zhou, J. Q., Chen, R. K., Zhang, F. J., Zhao, X. W., Duan, W. C., Wang, Y. M., Liu, J., Bao, J. J., Zhang, Z. Y. \& Liu, X. Z. (2018) A Novel TumorSuppressor, CDH18, Inhibits Glioma Cell Invasiveness Via UQCRC2 and Correlates with the Prognosis of Glioma Patients, Cellular physiology and biochemistry : international journal of experimental cellular physiology, biochemistry, and pharmacology. 48, 1755-1770.

139. Ellinger, J., Gromes, A., Poss, M., Bruggemann, M., Schmidt, D., Ellinger, N., Tolkach, Y., Dietrich, D., Kristiansen, G. \& Muller, S. C. (2016) Systematic expression analysis of the mitochondrial complex 
III subunits identifies UQCRC1 as biomarker in clear cell renal cell carcinoma, Oncotarget. 7, 8649086499.

140. Bottani, E., Cerutti, R., Harbour, M. E., Ravaglia, S., Dogan, S. A., Giordano, C., Fearnley, I. M., D'Amati, G., Viscomi, C., Fernandez-Vizarra, E. \& Zeviani, M. (2017) TTC19 Plays a Husbandry Role on UQCRFS1 Turnover in the Biogenesis of Mitochondrial Respiratory Complex III, Molecular cell. 67, 96105 e4.

141. Dennerlein, S., Oeljeklaus, S., Jans, D., Hellwig, C., Bareth, B., Jakobs, S., Deckers, M., Warscheid, B. \& Rehling, P. (2015) MITRAC7 Acts as a COX1-Specific Chaperone and Reveals a Checkpoint during Cytochrome c Oxidase Assembly, Cell reports. 12, 1644-55.

142. Dennerlein, S. \& Rehling, P. (2015) Human mitochondrial COX1 assembly into cytochrome c oxidase at a glance, Journal of cell science. 128, 833-7.

143. Balsa, E., Marco, R., Perales-Clemente, E., Szklarczyk, R., Calvo, E., Landazuri, M. O. \& Enriquez, J. A. (2012) NDUFA4 is a subunit of complex IV of the mammalian electron transport chain, Cell metabolism. 16, 378-86.

144. Pitceathly, R. D., Rahman, S., Wedatilake, Y., Polke, J. M., Cirak, S., Foley, A. R., Sailer, A., Hurles, M. E., Stalker, J., Hargreaves, I., Woodward, C. E., Sweeney, M. G., Muntoni, F., Houlden, H., Taanman, J. W., Hanna, M. G. \& Consortium, U. K. (2013) NDUFA4 mutations underlie dysfunction of a cytochrome c oxidase subunit linked to human neurological disease, Cell reports. 3, 1795-805.

145. Tanaka, T., Hosoi, F., Yamaguchi-Iwai, Y., Nakamura, H., Masutani, H., Ueda, S., Nishiyama, A., Takeda, S., Wada, H., Spyrou, G. \& Yodoi, J. (2002) Thioredoxin-2 (TRX-2) is an essential gene regulating mitochondria-dependent apoptosis, The EMBO journal. 21, 1695-703.

146. Nalvarte, I., Damdimopoulos, A. E. \& Spyrou, G. (2004) Human mitochondrial thioredoxin reductase reduces cytochrome $\mathrm{c}$ and confers resistance to complex III inhibition, Free radical biology \& medicine. 36, 1270-8.

147. Jonckheere, A. I., Smeitink, J. A. \& Rodenburg, R. J. (2012) Mitochondrial ATP synthase: architecture, function and pathology, Journal of inherited metabolic disease. 35, 211-25.

148. Buchert, F., Konno, H. \& Hisabori, T. (2015) Redox regulation of CF1-ATPase involves interplay between the gamma-subunit neck region and the turn region of the betaDELSEED-loop, Biochimica et biophysica acta. 1847, 441-450.

149. Kim, Y., Konno, H., Sugano, Y. \& Hisabori, T. (2011) Redox regulation of rotation of the cyanobacterial F1-ATPase containing thiol regulation switch, The Journal of biological chemistry. 286, 9071-8.

150. Belogrudov, G. I. \& Hatefi, Y. (2002) Factor B and the mitochondrial ATP synthase complex, The Journal of biological chemistry. 277, 6097-103.

151. Spiekerkoetter, U., Khuchua, Z., Yue, Z., Bennett, M. J. \& Strauss, A. W. (2004) General mitochondrial trifunctional protein (TFP) deficiency as a result of either alpha- or beta-subunit mutations exhibits similar phenotypes because mutations in either subunit alter TFP complex expression and subunit turnover, Pediatric research. 55, 190-6.

152. Ibdah, J. A., Perlegas, P., Zhao, Y., Angdisen, J., Borgerink, H., Shadoan, M. K., Wagner, J. D., Matern, D., Rinaldo, P. \& Cline, J. M. (2005) Mice heterozygous for a defect in mitochondrial trifunctional protein develop hepatic steatosis and insulin resistance, Gastroenterology. 128, 138190.

153. Chen, J., Young, M. E., Chatham, J. C., Crossman, D. K., Dell'Italia, L. J. \& Shalev, A. (2016) TXNIP regulates myocardial fatty acid oxidation via miR-33a signaling, American journal of physiology Heart and circulatory physiology. 311, H64-75.

154. Schwer, B., Bunkenborg, J., Verdin, R. O., Andersen, J. S. \& Verdin, E. (2006) Reversible lysine acetylation controls the activity of the mitochondrial enzyme acetyl-CoA synthetase 2, Proceedings of the National Academy of Sciences of the United States of America. 103, 10224-10229.

155. Forsyth, R., Vockley, C. W., Edick, M. J., Cameron, C. A., Hiner, S. J., Berry, S. A., Vockley, J., Arnold, G. L. \& Inborn Errors of Metabolism, C. (2016) Outcomes of cases with 3-methylcrotonyl-CoA carboxylase (3-MCC) deficiency - Report from the Inborn Errors of Metabolism Information System, Molecular genetics and metabolism. 118, 15-20. 
156. Zandberg, L., van Dyk, H. C., van der Westhuizen, F. H. \& van Dijk, A. A. (2016) A 3methylcrotonyl-CoA carboxylase deficient human skin fibroblast transcriptome reveals underlying mitochondrial dysfunction and oxidative stress, The international journal of biochemistry \& cell biology. 78, 116-129.

157. Strickland, K. C., Krupenko, N. I., Dubard, M. E., Hu, C. J., Tsybovsky, Y. \& Krupenko, S. A. (2011) Enzymatic properties of ALDH1L2, a mitochondrial 10-formyltetrahydrofolate dehydrogenase, Chemico-biological interactions. 191, 129-36.

158. Lan, X., Field, M. S. \& Stover, P. J. (2018) Cell cycle regulation of folate-mediated one-carbon metabolism, Wiley interdisciplinary reviews Systems biology and medicine, e1426.

159. Bonifati, V., Rizzu, P., van Baren, M. J., Schaap, O., Breedveld, G. J., Krieger, E., Dekker, M. C., Squitieri, F., Ibanez, P., Joosse, M., van Dongen, J. W., Vanacore, N., van Swieten, J. C., Brice, A., Meco, G., van Duijn, C. M., Oostra, B. A. \& Heutink, P. (2003) Mutations in the DJ-1 gene associated with autosomal recessive early-onset parkinsonism, Science. 299, 256-9.

160. Fernandez-Caggiano, M., Schroder, E., Cho, H. J., Burgoyne, J., Barallobre-Barreiro, J., Mayr, M. \& Eaton, P. (2016) Oxidant-induced Interprotein Disulfide Formation in Cardiac Protein DJ-1 Occurs via an Interaction with Peroxiredoxin 2, The Journal of biological chemistry. 291, 10399-410.

161. Terron, A., Bal-Price, A., Paini, A., Monnet-Tschudi, F., Bennekou, S. H., Members, E. W. E., Leist, M. \& Schildknecht, S. (2018) An adverse outcome pathway for parkinsonian motor deficits associated with mitochondrial complex I inhibition, Archives of toxicology. 92, 41-82.

162. Wang, J., Duhart, H. M., Xu, Z., Patterson, T. A., Newport, G. D. \& Ali, S. F. (2008) Comparison of the time courses of selective gene expression and dopaminergic depletion induced by MPP+ in MN9D cells, Neurochemistry international. 52, 1037-43.

163. Holzerova, E., Danhauser, K., Haack, T. B., Kremer, L. S., Melcher, M., Ingold, I., Kobayashi, S., Terrile, C., Wolf, P., Schaper, J., Mayatepek, E., Baertling, F., Friedmann Angeli, J. P., Conrad, M., Strom, T. M., Meitinger, T., Prokisch, H. \& Distelmaier, F. (2016) Human thioredoxin 2 deficiency impairs mitochondrial redox homeostasis and causes early-onset neurodegeneration, Brain : $a$ journal of neurology. 139, 346-54.

164. Havugimana, P. C., Hart, G. T., Nepusz, T., Yang, H., Turinsky, A. L., Li, Z., Wang, P. I., Boutz, D. R., Fong, V., Phanse, S., Babu, M., Craig, S. A., Hu, P., Wan, C., Vlasblom, J., Dar, V. U., Bezginov, A., Clark, G. W., Wu, G. C., Wodak, S. J., Tillier, E. R., Paccanaro, A., Marcotte, E. M. \& Emili, A. (2012) A census of human soluble protein complexes, Cell. 150, 1068-81.

165. Rolland, T., Tasan, M., Charloteaux, B., Pevzner, S. J., Zhong, Q., Sahni, N., Yi, S., Lemmens, I., Fontanillo, C., Mosca, R., Kamburov, A., Ghiassian, S. D., Yang, X., Ghamsari, L., Balcha, D., Begg, B. E., Braun, P., Brehme, M., Broly, M. P., Carvunis, A. R., Convery-Zupan, D., Corominas, R., CoulombeHuntington, J., Dann, E., Dreze, M., Dricot, A., Fan, C., Franzosa, E., Gebreab, F., Gutierrez, B. J., Hardy, M. F., Jin, M., Kang, S., Kiros, R., Lin, G. N., Luck, K., MacWilliams, A., Menche, J., Murray, R. R., Palagi, A., Poulin, M. M., Rambout, X., Rasla, J., Reichert, P., Romero, V., Ruyssinck, E., Sahalie, J. M., Scholz, A., Shah, A. A., Sharma, A., Shen, Y., Spirohn, K., Tam, S., Tejeda, A. O., Trigg, S. A., Twizere, J. C., Vega, K., Walsh, J., Cusick, M. E., Xia, Y., Barabasi, A. L., lakoucheva, L. M., Aloy, P., De Las Rivas, J., Tavernier, J., Calderwood, M. A., Hill, D. E., Hao, T., Roth, F. P. \& Vidal, M. (2014) A proteome-scale map of the human interactome network, Cell. 159, 1212-1226.

166. Wan, C., Borgeson, B., Phanse, S., Tu, F., Drew, K., Clark, G., Xiong, X., Kagan, O., Kwan, J., Bezginov, A., Chessman, K., Pal, S., Cromar, G., Papoulas, O., Ni, Z., Boutz, D. R., Stoilova, S., Havugimana, P. C., Guo, X., Malty, R. H., Sarov, M., Greenblatt, J., Babu, M., Derry, W. B., Tillier, E. R., Wallingford, J. B., Parkinson, J., Marcotte, E. M. \& Emili, A. (2015) Panorama of ancient metazoan macromolecular complexes, Nature. 525, 339-44. 
Table 1. Human mitochondrial proteins interacting with $\operatorname{Trx} 2$ as revealed by proteomics, Y2H screens and BioGRID. NC corresponds to non-covalent interaction; $\mathrm{C}$ to covalent. The four protein species in gray background correspond to mitochondrial proteins (combination of MitoCarta2.0 and BioGRID) described as interacting with Trx2.

\begin{tabular}{|c|c|c|c|c|c|}
\hline \# & $\begin{array}{c}\text { UniProt } \\
\text { KB }\end{array}$ & Protein species & Gene & $\begin{array}{c}\text { Interaction } \\
\text { confirmed } \\
\text { by }\end{array}$ & $\begin{array}{c}\text { Type of } \\
\text { interaction } \\
(\mathrm{NC} \text { or } \mathrm{C})\end{array}$ \\
\hline 1 & Q99798 & Aconitate hydratase, mitochondrial, & $\mathrm{ACO} 2$ & DTT & $\mathrm{C}$ \\
\hline 2 & Q9NUB1 & $\begin{array}{l}\text { Acetyl-coenzyme A synthetase 2-like, } \\
\text { mitochondrial }\end{array}$ & ACSS1 & DTT & $\mathrm{C}$ \\
\hline 3 & O75891 & Cytosolic 10-formyltetrahydrofolate dehydrogenase & ALDH1L1 & DTT & $\mathrm{C}$ \\
\hline 4 & P05091 & Aldehyde dehydrogenase, mitochondrial & ALDH2 & Acid & $\mathrm{NC}$ \\
\hline 5 & P25705 & ATP synthase subunit alpha, mitochondrial & ATP5F1A & Acid, DTT & $\mathrm{NC}, \mathrm{C}$ \\
\hline 6 & P06576 & ATP synthase subunit beta, mitochondrial & ATP5F1B & Acid, DTT & $\mathrm{NC}, \mathrm{C}$ \\
\hline 7 & O75947 & ATP synthase subunit $\mathrm{d}$, mitochondrial & ATP5PD & Acid, DTT & $\mathrm{NC}, \mathrm{C}$ \\
\hline 8 & O75828 & Carbonyl reductase [NADPH] 3 & CBR3 & DTT & $\mathrm{C}$ \\
\hline 9 & P17540 & Creatine kinase S-type, mitochondrial & CKMT2 & DTT & $\mathrm{C}$ \\
\hline 10 & P47985 & $\begin{array}{c}\text { Cytochrome b-cl complex subunit Rieske, } \\
\text { mitochondrial }\end{array}$ & UQCRFS1 & Acid, DTT & $\mathrm{NC}, \mathrm{C}$ \\
\hline 11 & Q08426 & Peroxisomal bifunctional enzyme & EHHADH & DTT & $\mathrm{C}$ \\
\hline 12 & P04406 & Glyceraldehyde-3-phosphate dehydrogenase & GAPDH & Acid, DTT & $\mathrm{NC}, \mathrm{C}$ \\
\hline 13 & P40939 & Trifunctional enzyme subunit alpha, mitochondrial & HADHA & Acid & $\mathrm{NC}$ \\
\hline 14 & P38646 & Stress-70 protein, mitochondrial & HSPA9 & DTT & $\mathrm{C}$ \\
\hline 15 & P10809 & $60 \mathrm{kDa}$ heat shock protein, mitochondrial & HSPD1 & DTT & $\mathrm{C}$ \\
\hline 16 & O75874 & Isocitrate dehydrogenase [NADP] cytoplasmic & IDH1 & Acid & $\mathrm{NC}$ \\
\hline 17 & $\mathrm{P} 48735$ & Isocitrate dehydrogenase [NADP], mitochondrial & IDH2 & Acid & $\mathrm{NC}$ \\
\hline 18 & P50213 & $\begin{array}{c}\text { Isocitrate dehydrogenase [NAD] subunit alpha, } \\
\text { mitochondrial }\end{array}$ & IDH3A & DTT & $\mathrm{C}$ \\
\hline 19 & P51553 & $\begin{array}{l}\text { Isocitrate dehydrogenase [NAD] subunit gamma, } \\
\text { mitochondrial }\end{array}$ & IDH3G & Acid & $\mathrm{NC}$ \\
\hline 20 & Q16891 & MICOS complex subunit MIC60 & IMMT & DTT & $\mathrm{C}$ \\
\hline 21 & P07195 & L-lactate dehydrogenase B chain, LDH-B & LDHB & Acid & $\mathrm{NC}$ \\
\hline 22 & Q86WU2 & Probable D-lactate dehydrogenase, mitochondrial & LDHD & DTT & $\mathrm{C}$ \\
\hline 23 & Q9BQ69 & O-acetyl-ADP-ribose deacetylase MACROD1 & $\begin{array}{l}\text { MACROD } \\
1\end{array}$ & DTT & $\mathrm{C}$ \\
\hline 24 & Q9HCC0 & $\begin{array}{c}\text { Methylcrotonoyl-CoA carboxylase beta chain, } \\
\text { mitochondrial, }\end{array}$ & $\mathrm{MCCC} 2$ & Acid & $\mathrm{NC}$ \\
\hline 25 & & Mitochondrially encoded 16S RNA & $M T-R N R 2$ & Y2H rat & $\mathrm{NC}$ \\
\hline 26 & Q9UJ68 & $\begin{array}{l}\text { Mitochondrial peptide methionine sulfoxide } \\
\text { reductase }\end{array}$ & MSRA & DTT & $\mathrm{C}$ \\
\hline 27 & P00395 & Cytochrome c oxidase subunit 1 & MT-CO1 & Y2H rat & $\mathrm{NC}$ \\
\hline 28 & O00483 & Cytochrome c oxidase subunit NDUFA4 & NDUFA4 & Acid & $\mathrm{NC}$ \\
\hline 29 & P28331 & $\begin{array}{l}\text { NADH-ubiquinone oxidoreductase } 75 \mathrm{kDa} \text { subunit, } \\
\text { mitochondrial }\end{array}$ & NDUFS1 & Acid & $\mathrm{NC}$ \\
\hline
\end{tabular}




\begin{tabular}{|c|c|c|c|c|c|}
\hline 30 & O75306 & $\begin{array}{l}\text { NADH dehydrogenase [ubiquinone] iron-sulfur } \\
\text { protein } 2 \text {, mitochondrial }\end{array}$ & NDUFS2 & Acid & $\mathrm{NC}$ \\
\hline 31 & O75489 & $\begin{array}{l}\text { NADH dehydrogenase [ubiquinone] iron-sulfur } \\
\text { protein } 3 \text {, mitochondrial }\end{array}$ & NDUFS3 & Acid & $\mathrm{NC}$ \\
\hline 32 & P49821 & $\begin{array}{c}\text { NADH dehydrogenase [ubiquinone] flavoprotein 1, } \\
\text { mitochondrial }\end{array}$ & NDUFV1 & Acid & $\mathrm{NC}$ \\
\hline 33 & A8MXV4 & Nucleoside diphosphate-linked moiety X motif 19 & NUDT19 & DTT & $\mathrm{C}$ \\
\hline 34 & P07237 & Protein disulfide-isomerase & $\mathrm{P} 4 \mathrm{HB}$ & $\begin{array}{c}\mathrm{Y} 2 \mathrm{H} \\
\text { human }\end{array}$ & $\mathrm{NC}$ \\
\hline 35 & Q99497 & Protein/nucleic acid deglycase DJ-1 & PARK7 & DTT & $\mathrm{C}$ \\
\hline 36 & P08559 & $\begin{array}{l}\text { Pyruvate dehydrogenase E1 component subunit } \\
\text { alpha, somatic form, mitochondrial }\end{array}$ & PDHA1 & Acid & $\mathrm{NC}$ \\
\hline 37 & P11177 & $\begin{array}{l}\text { Pyruvate dehydrogenase E1 component subunit } \\
\text { beta, mitochondrial }\end{array}$ & PDHB & DTT & $\mathrm{C}$ \\
\hline 38 & Q9H2U2 & Inorganic pyrophosphatase 2 , mitochondrial & PPA2 & DTT & $\mathrm{C}$ \\
\hline 39 & P32119 & Peroxiredoxin-2 & PRDX2 & Acid, DTT & $\mathrm{NC}, \mathrm{C}$ \\
\hline 40 & P30048 & $\begin{array}{l}\text { Thioredoxin-dependent peroxide reductase, } \\
\text { mitochondrial (Peroxiredoxin-3) }\end{array}$ & PRDX3 & DTT & $\mathrm{C}$ \\
\hline 41 & Q13162 & Peroxiredoxin-4 & PRDX4 & Acid, DTT & $\mathrm{NC}, \mathrm{C}$ \\
\hline 42 & P30044 & Peroxiredoxin-5 & PRDX5 & Acid, DTT & $\mathrm{NC}, \mathrm{C}$ \\
\hline 43 & P30041 & Peroxiredoxin-6 & PRDX6 & DTT & $\mathrm{C}$ \\
\hline 44 & P62269 & 40S ribosomal protein $\mathrm{S} 18$ & RPS18 & Acid & $\mathrm{NC}$ \\
\hline 45 & P31040 & $\begin{array}{l}\text { Succinate dehydrogenase [ubiquinone] } \\
\text { flavoprotein subunit }\end{array}$ & SDHA & Acid & $\mathrm{NC}$ \\
\hline 46 & P60174 & Triosephosphate isomerase & TPI1 & Acid, DTT & $\mathrm{NC}, \mathrm{C}$ \\
\hline 47 & P49411 & Elongation factor $\mathrm{Tu}$, mitochondrial, EF-Tu & TUFM & DTT & $\mathrm{C}$ \\
\hline 48 & P31930 & Cytochrome b-c1 complex subunit 1 , mitochondrial & UQCRC1 & DTT & $\mathrm{C}$ \\
\hline 49 & P22695 & Cytochrome b-c1 complex subunit 2, mitochondrial & UQCRC2 & Acid & $\mathrm{NC}$ \\
\hline 50 & Q16540 & Mitochondrial ribosomal protein L23 & MRPL23 & \multicolumn{2}{|c|}{$\begin{array}{l}\text { Co fractionation/BioGRID } \\
\text { [164] }\end{array}$} \\
\hline 51 & P49247 & Ribose 5-phosphate isomerase A & RPIA & \multicolumn{2}{|c|}{ BioGRID [165] } \\
\hline 52 & P00441 & Superoxide dismutase 1 , soluble & SOD1 & \multicolumn{2}{|c|}{$\begin{array}{l}\text { Co fractionation/BioGRID } \\
{[166]}\end{array}$} \\
\hline 53 & Q9NS69 & $\begin{array}{l}\text { Translocase of outer mitochondrial membrane } 22 \\
\text { homolog }\end{array}$ & TOMM22 & \multicolumn{2}{|c|}{$\begin{array}{l}\text { Co fractionation/BioGRID } \\
\text { [164] }\end{array}$} \\
\hline
\end{tabular}




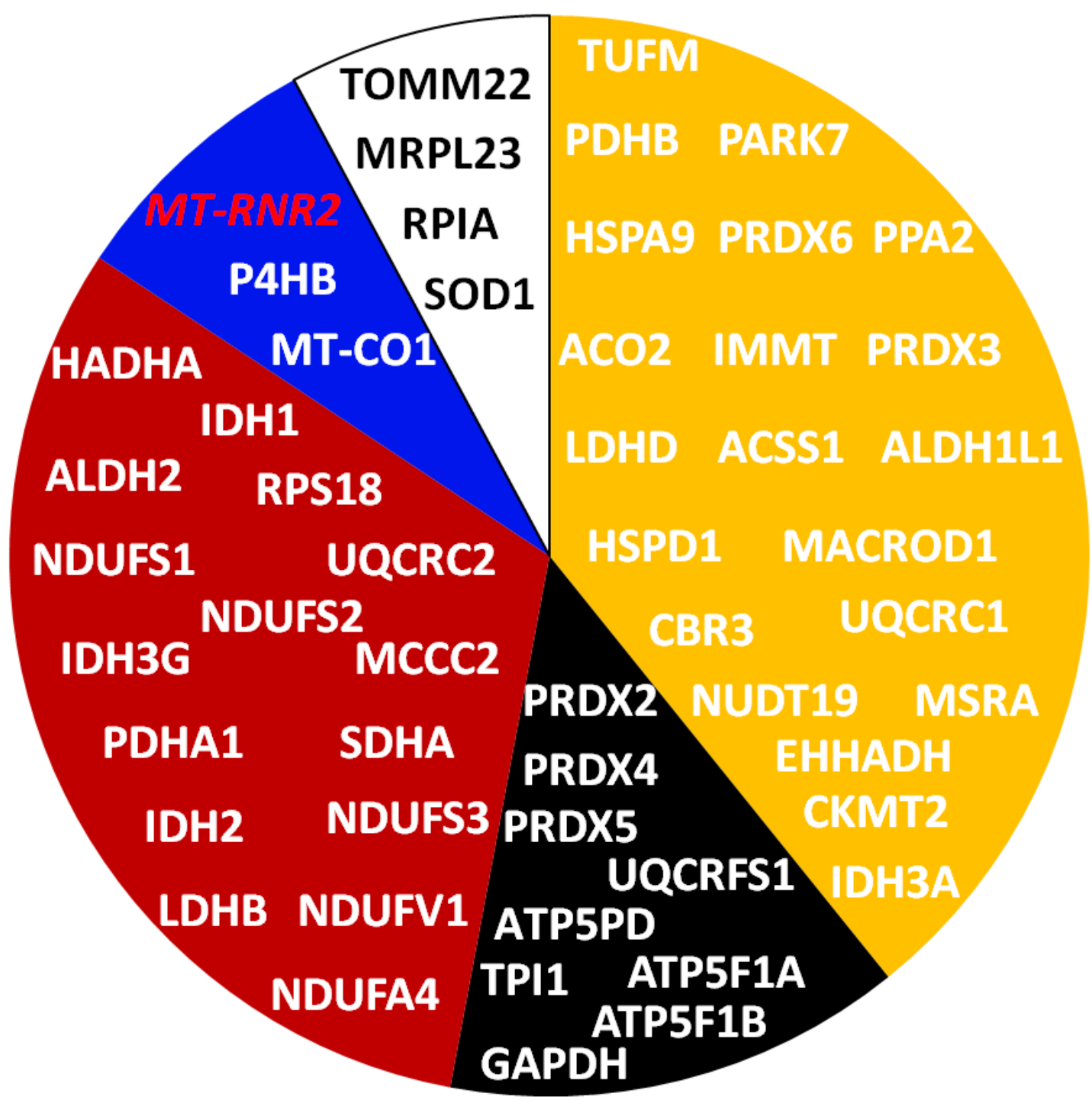

Figure 1: The human Trx2 mitochondrial interactome. Proteins are presented by their primary gene names (table 1). In summary, 21 proteins were eluted by DTT (yellow), 16 by acid (red), and 9 proteins were eluted by both acid and DTT (black). The blue slice represents data from Y2H screens where the mitochondrial 16S RNA gene is in red letters. The white slice contains the four mitochondrial interactors of Trx 2 from the BioGRID data base [26]. 

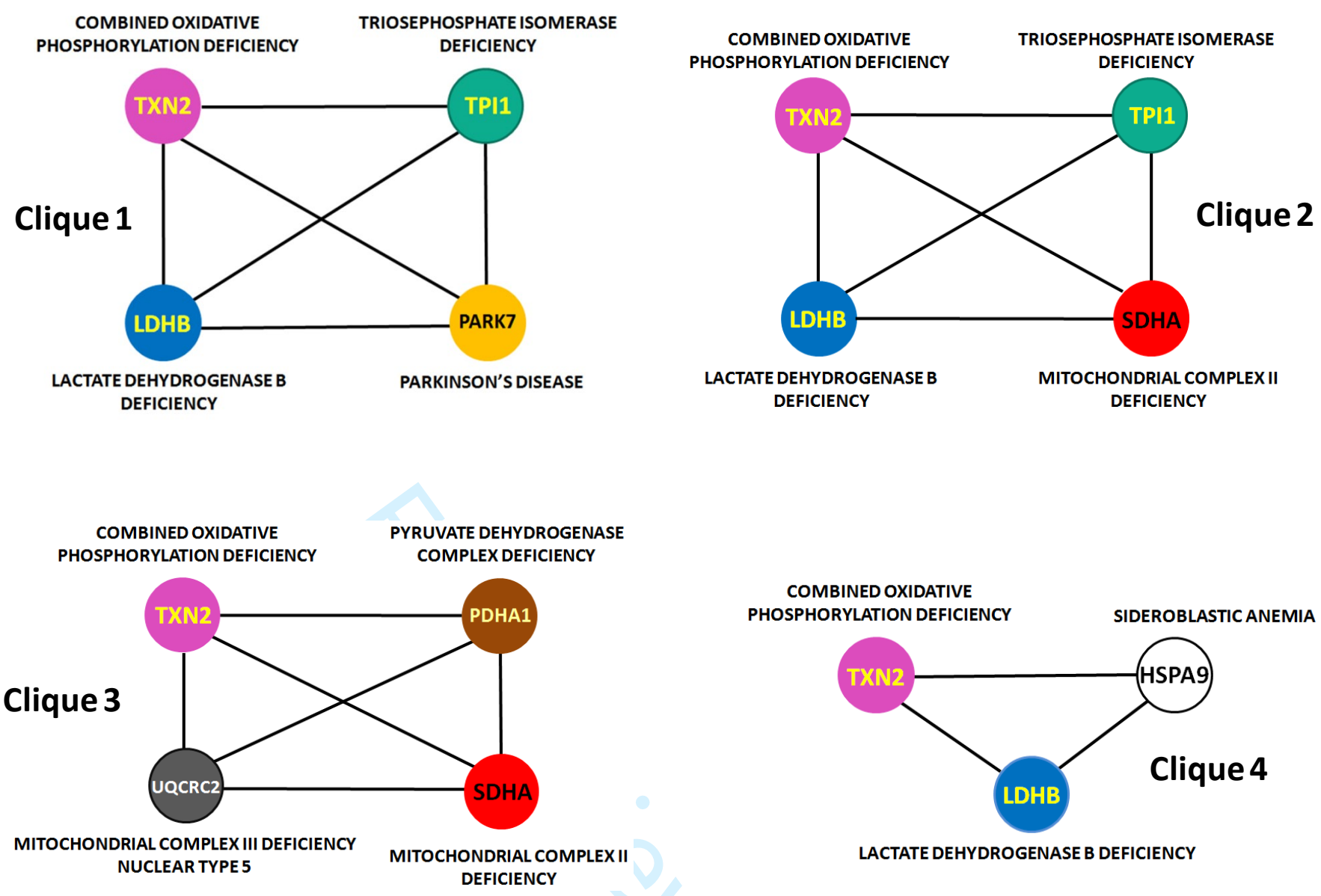

Fig 2: Four cliques of the diseasome of Trx2. The diseasome is based on the Trx 2 mitochondrial interactome. The disease-related genes/proteins are shown with capital letters within the circular nodes of each clique (Unipot IDs are provided on supplementary table 2.5). The lines connecting different nodes (genes) indicate the herein supported interactions for Trx2 and the interactions among the interactors of Trx2 (data from BioGRID). 

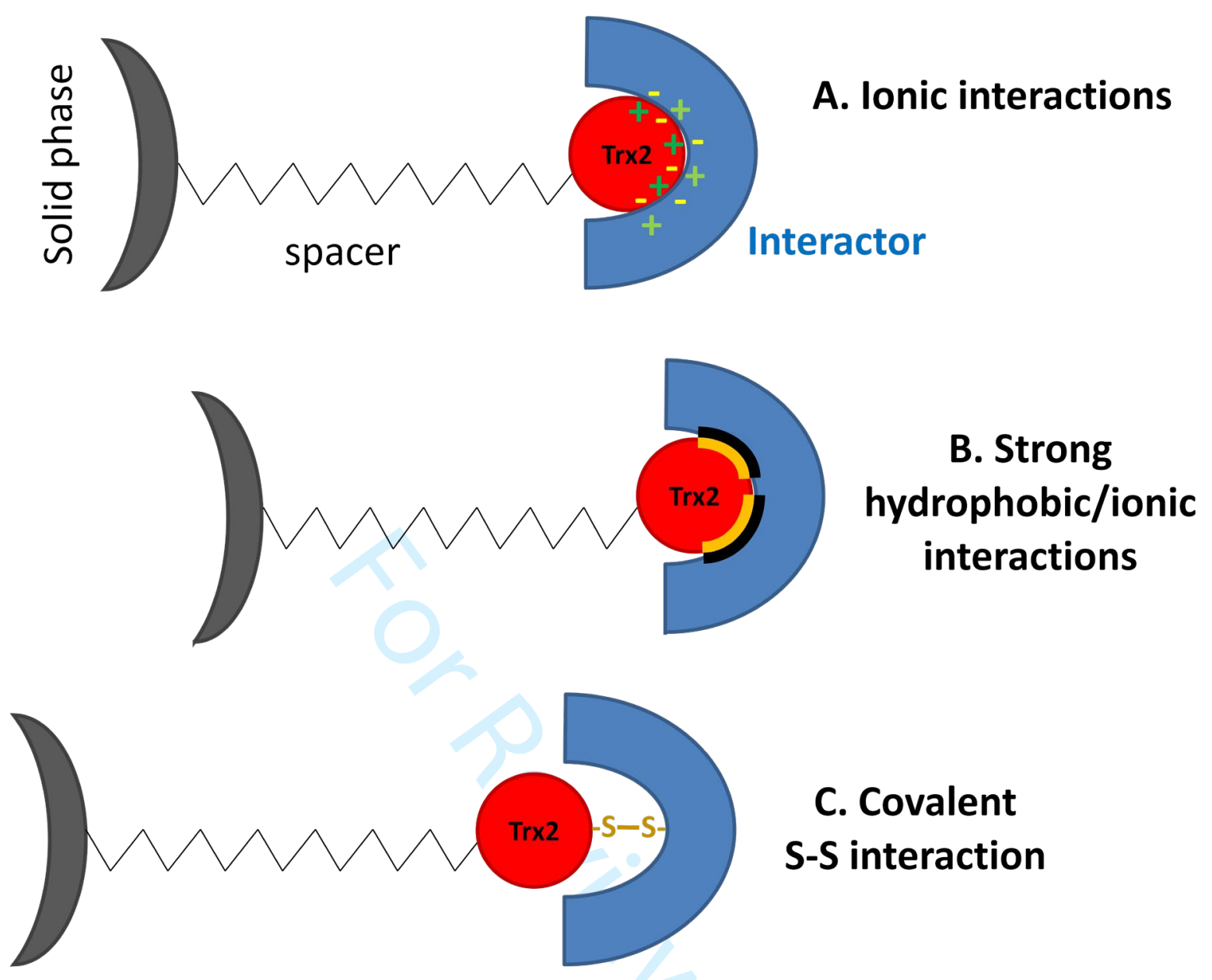

Fig. 3. Proposed interactions of $\operatorname{Trx} 2$ with potential substrates. 3A: weak ionic interactions; 3B: strong hydrophobic interactions (interacting hydrophobic areas in black and yellow); 3C: covalent interactions via a disulfide between $\Delta \operatorname{Trx} 2 \mathrm{C} 93 \mathrm{~S}$ and interactor. 


\section{Supplementary figures}

\section{Supplementary figure 1. Alignment of mouse, rat and human Trx2 lacking their} mitochondrial targeting sequene. All different amino acids are highlighted in yellow background. Alignment was performed using the CLUSTAL O(1.2.4) multiple sequence alignment tool (https://www.ebi.ac.uk/Tools/msa/clustalo/).

mouse $\operatorname{Trx} 2$

rat $\operatorname{Trx} 2$

human Trx2

TTFNVQDGP DFQDRVVNSETPVVVDFHAQWCGPCKILGPRLEKMVAKQHGKVVMAKVDID 


\section{Supplementary figure 2. Elution profile of $\triangle \mathrm{Trx2C93S}$ on a DEAE FF column.}

Chromatography was carried out in $20 \mathrm{mM}$ Bis-Tris-HCl, pH 6,7 and a 0-1 M NaCl gradient (light green line). The other shown lines correspond to: conductivity (brown line); $\mathrm{A}_{280}$ (blue); $\mathrm{A}_{254}$ (magenta); $\mathrm{A}_{310}$ (red). $\Delta \operatorname{Trx} 2 \mathrm{C} 93 \mathrm{~S}$ was eluted at $\sim 15 \mathrm{mS} / \mathrm{cm}$ (black arrow). (i) whole chromatogram, (ii) partial chromatogram.

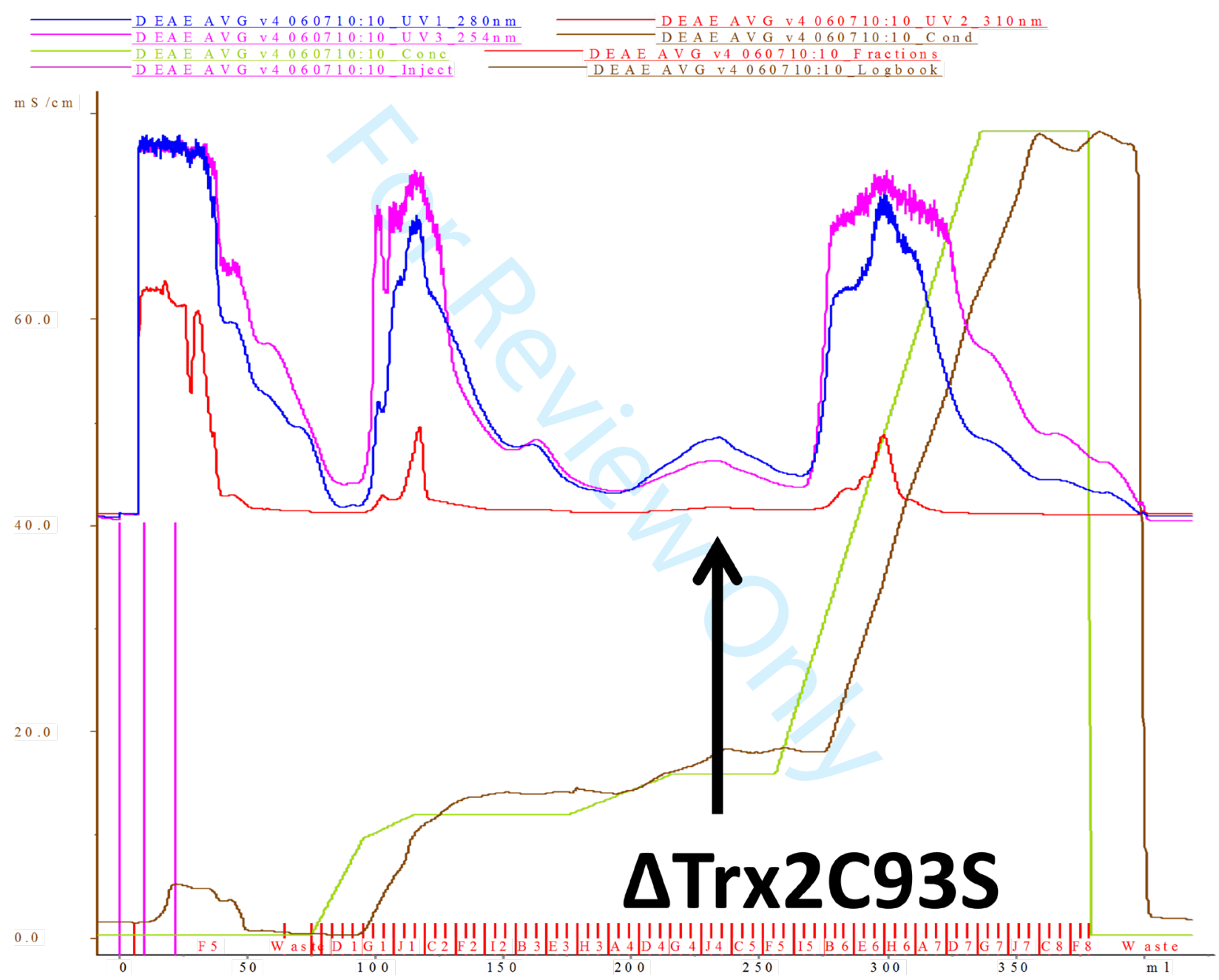

\section{Supplementary figure 2 (i).}




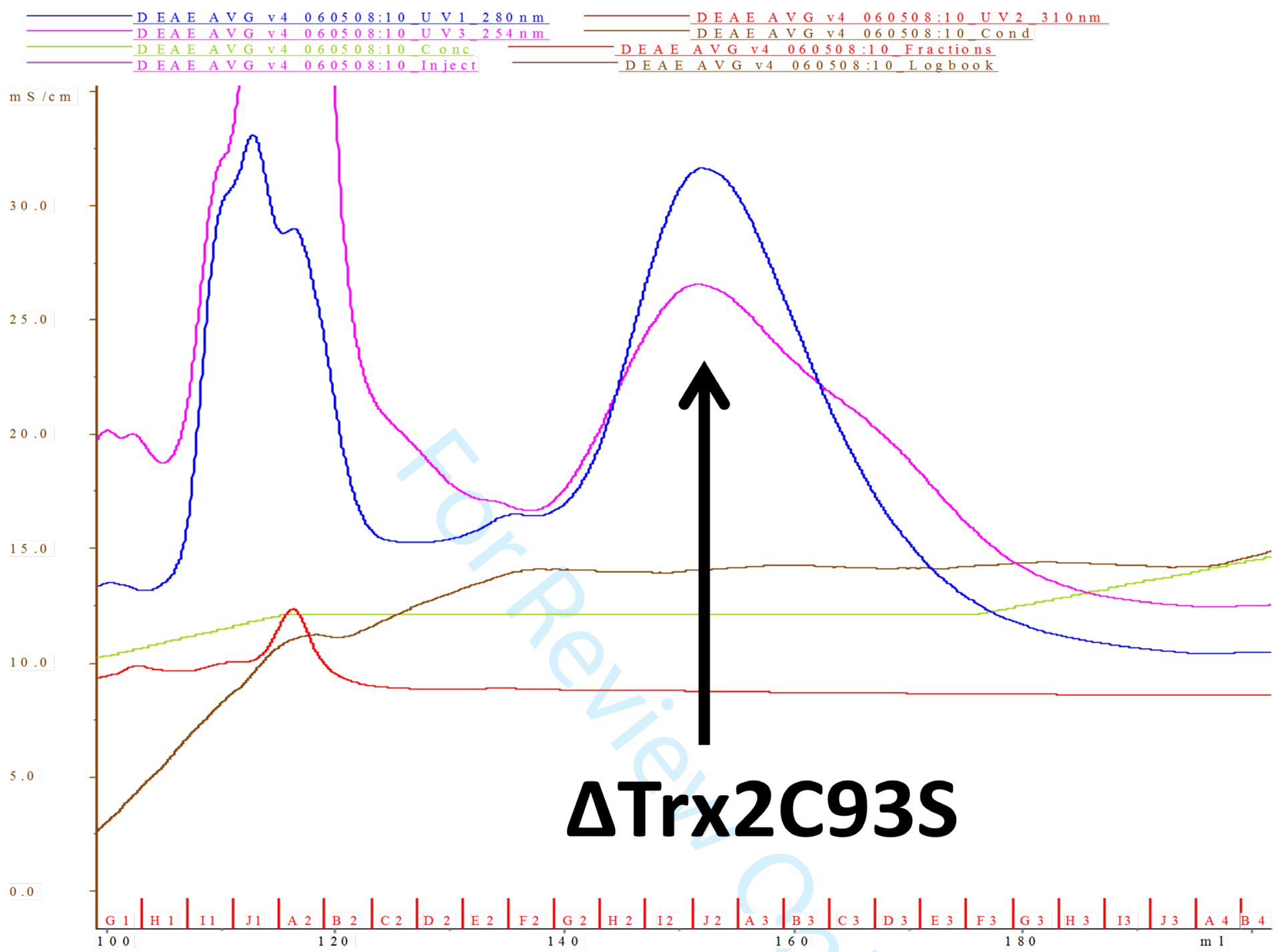

Supplementary figure 2 (ii). 
Supplementary figure 3. Western blots of fractions derived by centrifugation gradient from cardiac muscle.

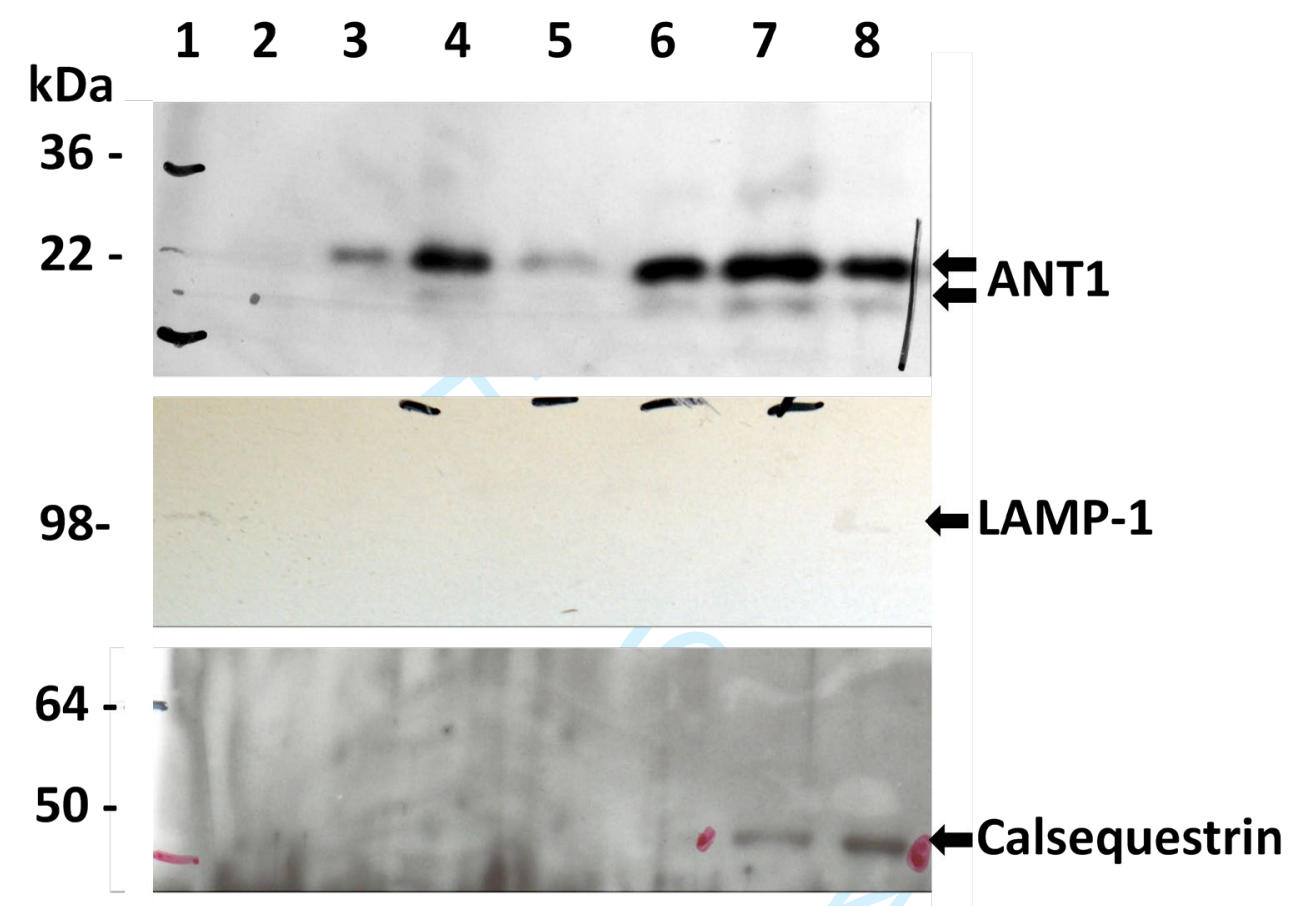

Analysis of sucrose gradient fractions, for mitochondrial (ANT1), lysosomal (LAMP-1) and ER (calsequestrin) proteins by Western blot in $10 \%$ SDS-PAGE. Lane 1: molecular weight protein markers, lanes 2-8: fractions from sucrose gradient. The respective antibody together with an arrow indicting the detected antigen (ANT 1, LAMP1, calsequestrin) are shown at the right side of each Western blot. Fractions corresponding to lanes 3, 4, and 6 were pooled as "mitochondrial" fractions and chromatographed on the $\Delta \operatorname{Trx} 2 \mathrm{C} 93 \mathrm{~S}$ affinity columns. The same criteria were set for the selection of mitochondrial fractions from brain, skeletal muscle. 


\section{Supplementary tables 1. Mass spec analysis of individual spots obtained from 2D (and 1D) electrophoresis}

\section{MS data for the interactors of Trx2 in different mouse tissues.}

Proteins were isolated and identified from 2D gels by MALDI-TOF-MS analysis, using the parameters described under Materials and Methods: \% coverage represents the percentage of total protein sequence by the identified peptides. The probability of a false identity was usually lower than $10^{-5}$. Spot numbering (Spot \#, left column) corresponds to the different spots/bands identified per experiment. The numbering is according to the alphabetical order of the protein species identified. The protein species identified according to the set criteria are numbered in the right column (\# of species) and are coloured in red. The individual experiments and their corresponding results are presented in the following tables.

Table 1.1: mass spec analysis of a 2D gel, of an acid-eluted fraction from a lysate derived from mouse lungs.

\begin{tabular}{|c|c|c|c|c|c|c|c|}
\hline $\begin{array}{c}\text { Spot } \\
\#\end{array}$ & Protein species & $\begin{array}{l}\text { Mascot } \\
\text { Score }\end{array}$ & $\begin{array}{c}\% \\
\text { Coverage }\end{array}$ & $\begin{array}{l}\text { Protein } \\
\text { MW }\end{array}$ & Accession & $\begin{array}{l}\text { Uniprot } \\
\text { ID }\end{array}$ & $\begin{array}{c}\text { \# of } \\
\text { species }\end{array}$ \\
\hline 1 & $\begin{array}{c}12 \text { days embryo spinal } \\
\text { ganglion cDNA, RIKEN full- } \\
\text { length enriched library, } \\
\text { clone:D130020I06 product:2 }\end{array}$ & 27 & 13 & 33405.48 & Q8BJI0_MOUSE & & \\
\hline 2 & $\begin{array}{l}16 \text { days embryo head cDNA, } \\
\text { RIKEN full-length enriched } \\
\text { library, clone:C130079C10 } \\
\text { product:carbonyl red }\end{array}$ & 42 & 26 & 26055.66 & Q542P5_MOUSE & & \\
\hline 3 & $\begin{array}{l}\text { 40S ribosomal protein S4, X } \\
\text { isoform - Mus musculus } \\
\text { (Mouse) }\end{array}$ & 106 & 49 & 29807.14 & RS4X_MOUSE & P62702 & 1 \\
\hline 4 & $\begin{array}{c}\text { 40S ribosomal protein SA - } \\
\text { Mus musculus (Mouse) }\end{array}$ & 151 & 54 & 32931.48 & RSSA_MOUSE & P14206 & 2 \\
\hline 5 & $\begin{array}{c}\text { Actin, cytoplasmic } 1 \text { - Mus } \\
\text { musculus (Mouse) }\end{array}$ & 160 & 63 & 42051.86 & ACTB_MOUSE & P60710 & 3 \\
\hline 6 & $\begin{array}{l}\text { Adult male testis cDNA, } \\
\text { RIKEN full-length enriched } \\
\text { library, clone:4930427I11 } \\
\text { product:similar to ZIN }\end{array}$ & 47 & 21 & 61098.16 & Q9D5K8_MOUSE & & \\
\hline 7 & $\begin{array}{c}\text { Aldehyde dehydrogenase, } \\
\text { mitochondrial precursor - Mus } \\
\text { musculus (Mouse) }\end{array}$ & 247 & 50 & 57014.94 & ALDH2_MOUSE & \multirow{2}{*}{ P47738 } & \multirow{2}{*}{4} \\
\hline 8 & $\begin{array}{c}\text { Aldehyde dehydrogenase, } \\
\text { mitochondrial precursor - Mus } \\
\text { musculus (Mouse) }\end{array}$ & 194 & 48 & 57014.94 & ALDH2_MOUSE & & \\
\hline 9 & $\begin{array}{c}\text { Alpha crystallin B chain - Mus } \\
\text { musculus (Mouse) }\end{array}$ & 109 & 54 & 20056.41 & CRYAB_MOUSE & P23927 & 5 \\
\hline
\end{tabular}




\begin{tabular}{|c|c|c|c|c|c|c|c|}
\hline 10 & $\begin{array}{l}\text { Alpha-centractin - Mus } \\
\text { musculus (Mouse) }\end{array}$ & 107 & 45 & 42700.95 & ACTZ_MOUSE & P61164 & 6 \\
\hline 11 & $\begin{array}{l}\text { Alpha-enolase - Mus } \\
\text { musculus (Mouse) }\end{array}$ & 167 & 63 & 47453.34 & ENOA_MOUSE & P17182 & 7 \\
\hline 12 & $\begin{array}{l}\text { ATP synthase subunit alpha, } \\
\text { mitochondrial precursor - Mus } \\
\text { musculus (Mouse) }\end{array}$ & 152 & 45 & 59829.63 & ATPA_MOUSE & Q03265 & 8 \\
\hline 13 & $\begin{array}{l}\text { ATP synthase subunit beta, } \\
\text { mitochondrial precursor - Mus } \\
\text { musculus (Mouse) }\end{array}$ & 144 & 56 & 56265.46 & ATPB_MOUSE & P56480 & 9 \\
\hline 14 & $\begin{array}{l}\text { Dihydropyrimidinase-related } \\
\text { protein } 2 \text { - Mus musculus } \\
\text { (Mouse) }\end{array}$ & 189 & 59 & 62637.74 & DPYL2_MOUSE & \multirow{3}{*}{ Q62188 } & \multirow{3}{*}{10} \\
\hline 15 & $\begin{array}{c}\text { Dihydropyrimidinase-related } \\
\text { protein } 2 \text { - Mus musculus } \\
\text { (Mouse) }\end{array}$ & 201 & 57 & 62637.74 & DPYL2_MOUSE & & \\
\hline 16 & $\begin{array}{c}\text { Dihydropyrimidinase-related } \\
\text { protein } 3 \text { - Mus musculus } \\
\text { (Mouse) }\end{array}$ & 221 & 64 & 62296.23 & DPYL3_MOUSE & & \\
\hline 17 & $\begin{array}{l}\text { F-actin capping protein } \\
\text { subunit alpha- } 1 \text { - Mus } \\
\text { musculus (Mouse) }\end{array}$ & 103 & 63 & 33090.37 & CAZA1_MOUSE & P47753 & 11 \\
\hline 18 & $\begin{array}{l}\text { F-actin capping protein } \\
\text { subunit alpha-2 - Mus } \\
\text { musculus (Mouse) }\end{array}$ & 136 & 82 & 33117.68 & CAZA2_MOUSE & \multirow{2}{*}{ P47754 } & \multirow{2}{*}{12} \\
\hline 19 & $\begin{array}{l}\text { F-actin capping protein } \\
\text { subunit alpha-2 - Mus } \\
\text { musculus (Mouse) }\end{array}$ & 166 & 76 & 33117.68 & CAZA2_MOUSE & & \\
\hline 20 & $\begin{array}{l}\text { Gelsolin precursor - Mus } \\
\text { musculus (Mouse) }\end{array}$ & 118 & 34 & 86287.23 & GELS_MOUSE & \multirow{2}{*}{ P13020 } & \multirow{2}{*}{13} \\
\hline 21 & $\begin{array}{l}\text { Gelsolin precursor - Mus } \\
\text { musculus (Mouse) }\end{array}$ & 134 & 35 & 86287.23 & GELS_MOUSE & & \\
\hline 22 & $\begin{array}{c}\text { Glyceraldehyde-3-phosphate } \\
\text { dehydrogenase - Mus } \\
\text { musculus (Mouse) }\end{array}$ & 68 & 34 & 36072.32 & G3P_MOUSE & P16858 & 14 \\
\hline 23 & $\begin{array}{l}\text { GTP-binding nuclear protein } \\
\text { Ran - Mus musculus (Mouse) }\end{array}$ & 159 & 50 & 24578.68 & RAN_MOUSE & P62827 & 15 \\
\hline 24 & $\begin{array}{l}\text { Hist1h2bj protein - Mus } \\
\text { musculus (Mouse) }\end{array}$ & 43 & 42 & 13570.43 & A0JLV3_MOUSE & & \\
\hline 25 & $\begin{array}{c}\text { Indolethylamine } \mathrm{N}- \\
\text { methyltransferase - Mus } \\
\text { musculus (Mouse) }\end{array}$ & 125 & 58 & 30068.05 & INMT_MOUSE & \multirow{3}{*}{ P40936 } & \multirow{3}{*}{17} \\
\hline 26 & $\begin{array}{l}\text { Indolethylamine } \mathrm{N}- \\
\text { methyltransferase - Mus } \\
\text { musculus (Mouse) }\end{array}$ & 89 & 50 & 30068.05 & INMT_MOUSE & & \\
\hline 27 & $\begin{array}{l}\text { Indolethylamine } \mathrm{N}- \\
\text { methyltransferase - Mus } \\
\text { musculus (Mouse) }\end{array}$ & 119 & 52 & 30068.05 & INMT_MOUSE & & \\
\hline 28 & $\begin{array}{c}\text { Isocitrate dehydrogenase } \\
\text { [NADP] cytoplasmic - Mus } \\
\text { musculus (Mouse) }\end{array}$ & 131 & 38 & 47029.56 & IDHC_MOUSE & P70404 & 18 \\
\hline 29 & $\begin{array}{c}\text { Isocitrate dehydrogenase } \\
{[\text { NADP], mitochondrial }} \\
\text { precursor - Mus musculus } \\
\text { (Mouse) }\end{array}$ & 123 & 38 & 59419.05 & IDHP_MOUSE & O88844 & 19 \\
\hline
\end{tabular}




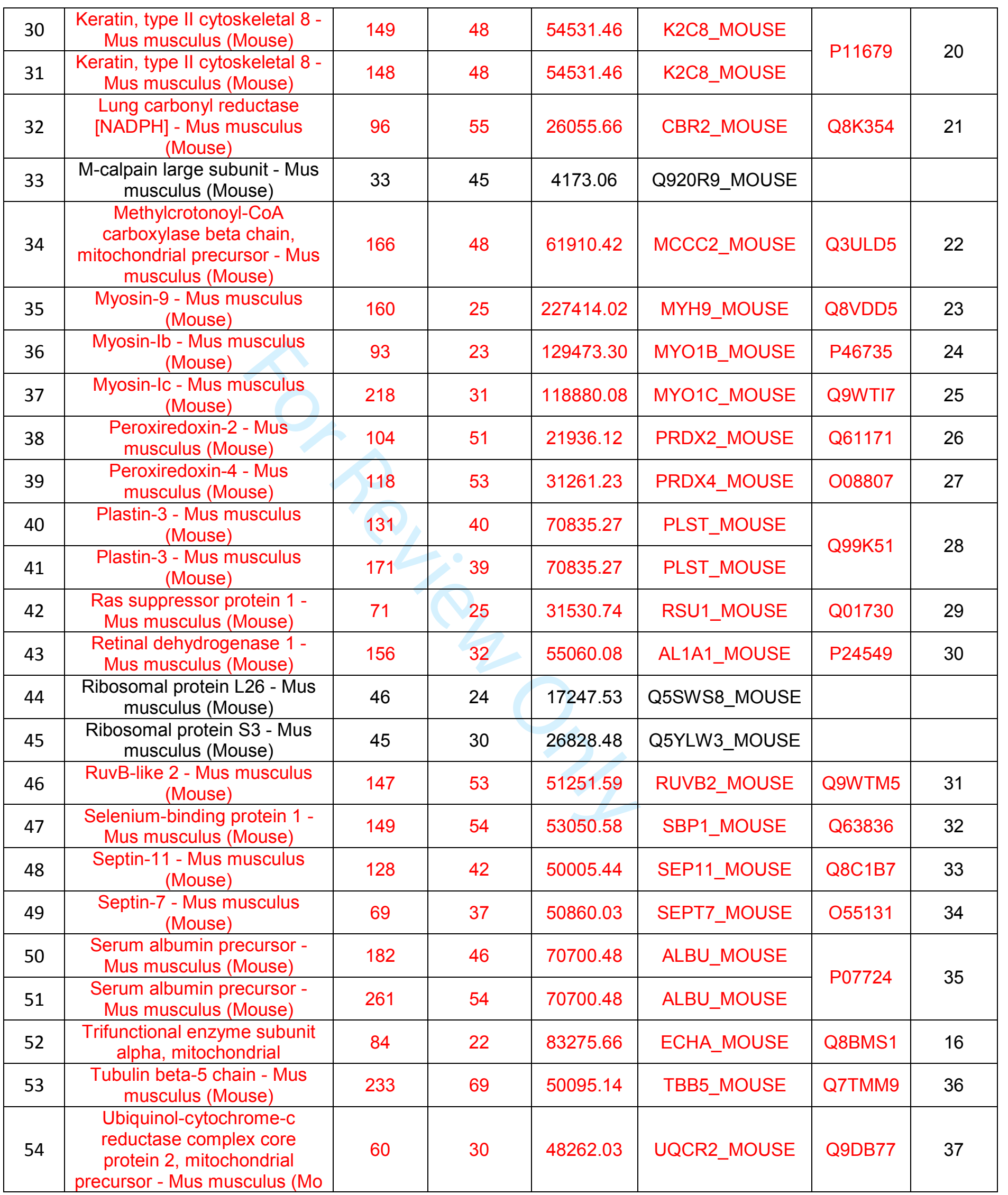


Table 1.2: mass spec analysis of a 2D gel of a DTT-eluted fraction from a lysate derived from mouse lungs. The analysis is for the proteins remaining on the affinity column after acidic elution has taken place.

\begin{tabular}{|c|c|c|c|c|c|c|c|}
\hline $\begin{array}{c}\text { Spot } \\
\#\end{array}$ & Protein species & $\begin{array}{c}\text { Mascot } \\
\text { Score }\end{array}$ & $\begin{array}{c}\% \\
\text { Coverage }\end{array}$ & $\begin{array}{l}\text { Protein } \\
\text { MW }\end{array}$ & Accession & $\begin{array}{c}\text { Uniprot } \\
\text { ID }\end{array}$ & $\begin{array}{c}\text { \# of } \\
\text { species }\end{array}$ \\
\hline 1 & $\begin{array}{c}0 \text { day neonate cerebellum } \\
\text { cDNA, RIKEN full-length } \\
\text { enriched library, } \\
\text { clone:C230064E07 } \\
\text { product:VIGILIN }\end{array}$ & 50 & 19 & 47099.10 & Q8BX68_MOUSE & & \\
\hline 2 & $\begin{array}{l}0 \text { day neonate eyeball cDNA, } \\
\text { RIKEN full-length enriched } \\
\text { library, clone:E130303L10 } \\
\text { product:acetyl-Coe }\end{array}$ & 35 & 16 & 44425.81 & Q3UPU8_MOUSE & & \\
\hline 3 & $\begin{array}{c}11 \text { days embryo whole body } \\
\text { cDNA, RIKEN full-length } \\
\text { enriched library, } \\
\text { clone:2700001D14 } \\
\text { product:Hypoth }\end{array}$ & 46 & 10 & 42224.17 & Q3V274_MOUSE & & \\
\hline 4 & $\begin{array}{l}12 \text { days embryo female } \\
\text { mullerian duct includes } \\
\text { surrounding region cDNA, } \\
\text { RIKEN full-length enriched I }\end{array}$ & 40 & 20 & 37475.98 & Q3UXL1_MOUSE & & \\
\hline 5 & $\begin{array}{c}13 \text { days embryo head cDNA, } \\
\text { RIKEN full-length enriched } \\
\text { library, clone:3110001F06 } \\
\text { product:cofilin 1, n }\end{array}$ & 39 & 27 & 18775.76 & Q544Y7_MOUSE & & \\
\hline 6 & $\begin{array}{c}16 \text { days embryo heart cDNA, } \\
\text { RIKEN full-length enriched } \\
\text { library, clone:I920194A06 } \\
\text { product:cofilin 2, }\end{array}$ & 32 & 18 & 18811.88 & Q3UHW9_MOUSE & & \\
\hline 7 & $\begin{array}{l}16 \text { days neonate cerebellum } \\
\text { cDNA, RIKEN full-length } \\
\text { enriched library, } \\
\text { clone: } 9630058118 \\
\text { product:weakl }\end{array}$ & 29 & 20 & 17699.11 & Q8BZ86_MOUSE & & \\
\hline 8 & $\begin{array}{c}182 \mathrm{kDa} \text { tankyrase } 1 \text {-binding } \\
\text { protein - Mus musculus } \\
\text { (Mouse) }\end{array}$ & 316 & 36 & 183025.90 & TB182_MOUSE & P58871 & 1 \\
\hline 9 & $\begin{array}{c}\text { 26S proteasome non-ATPase } \\
\text { regulatory subunit } 4 \text { - Mus } \\
\text { musculus (Mouse) }\end{array}$ & 89 & 36 & 40906.24 & PSMD4_MOUSE & O35226 & 2 \\
\hline 10 & 26S proteasome non-ATPase & 64 & 28 & 24875.63 & PSMD9_MOUSE & Q9CR00 & 3 \\
\hline
\end{tabular}




\begin{tabular}{|c|c|c|c|c|c|c|c|}
\hline & $\begin{array}{c}\text { regulatory subunit } 9 \text { - Mus } \\
\text { musculus (Mouse) }\end{array}$ & & & & & & \\
\hline 11 & $\begin{array}{c}3 \text { days neonate thymus } \\
\text { cDNA, RIKEN full-length } \\
\text { enriched library, } \\
\text { clone:A630013A09 } \\
\text { product:KINESIN SU }\end{array}$ & 30 & 9 & 64928.87 & Q8BY99_MOUSE & & \\
\hline 12 & $\begin{array}{c}8 \text { days embryo whole body } \\
\text { cDNA, RIKEN full-length } \\
\text { enriched library, } \\
\text { clone:5730531E12 } \\
\text { product:CHLORID }\end{array}$ & 41 & 23 & 27313.68 & Q9CYD1_MOUSE & & \\
\hline 13 & $\begin{array}{c}9.5 \text { days embryo } \\
\text { parthenogenote cDNA, } \\
\text { RIKEN full-length enriched } \\
\text { library, clone:B130044C16 } \\
\text { product:h }\end{array}$ & 44 & 18 & 54104.92 & Q8BRB8_MOUSE & & \\
\hline 14 & $\begin{array}{l}\text { 9.5 days embryo } \\
\text { parthenogenote cDNA, } \\
\text { RIKEN full-length enriched } \\
\text { library, clone:B130044C16 } \\
\text { product:h }\end{array}$ & 46 & 22 & 54104.92 & Q8BRB8_MOUSE & & \\
\hline 15 & $\begin{array}{l}9.5 \text { days embryo } \\
\text { parthenogenote cDNA, } \\
\text { RIKEN full-length enriched } \\
\text { library, clone:B130044C16 } \\
\text { product:h }\end{array}$ & 60 & 15 & 54104.92 & Q8BRB8_MOUSE & & \\
\hline 16 & $\begin{array}{l}\text { 9.5 days embryo } \\
\text { parthenogenote cDNA, } \\
\text { RIKEN full-length enriched } \\
\text { library, clone:B130044C16 } \\
\text { product:h }\end{array}$ & 64 & 24 & 54104.92 & Q8BRB8_MOUSE & \multirow{2}{*}{ Q8BRB8 } & \multirow[b]{2}{*}{4} \\
\hline 17 & $\begin{array}{l}\text { 9.5 days embryo } \\
\text { parthenogenote cDNA, } \\
\text { RIKEN full-length enriched } \\
\text { library, clone:B130044C16 } \\
\text { product:h }\end{array}$ & 82 & 18 & 54104.92 & Q8BRB8_MOUSE & & \\
\hline 18 & $\begin{array}{c}\text { Acid phosphatase 1, soluble - } \\
\text { Mus musculus (Mouse) }\end{array}$ & 39 & 24 & 18636.05 & Q4VAI2_MOUSE & & \\
\hline 19 & $\begin{array}{l}\text { Adult male kidney cDNA, } \\
\text { RIKEN full-length enriched } \\
\text { library, clone:0610039M20 } \\
\text { product:ribosomal prot }\end{array}$ & 48 & 31 & 14904.63 & Q6ZWZ6_MOUSE & & \\
\hline 20 & $\begin{array}{l}\text { Adult male testis cDNA, } \\
\text { RIKEN full-length enriched } \\
\text { library, clone:4922505E06 } \\
\text { product:calpastatin, f }\end{array}$ & 50 & 12 & 47508.65 & Q3TTN2_MOUSE & & \\
\hline 21 & $\begin{array}{l}\text { Adult male testis cDNA, } \\
\text { RIKEN full-length enriched } \\
\text { library, clone:4930429C23 } \\
\text { product:hypothetical p }\end{array}$ & 27 & 17 & 29785.00 & Q8CDS7_MOUSE & & \\
\hline 22 & $\begin{array}{c}\text { Akap8I protein - Mus } \\
\text { musculus (Mouse) }\end{array}$ & 36 & 18 & 39279.30 & Q80XE9_MOUSE & & \\
\hline 23 & $\begin{array}{c}\text { A-kinase anchor protein } 2 \text { - } \\
\text { Mus musculus (Mouse) }\end{array}$ & 237 & 37 & 99089.83 & AKAP2_MOUSE & 054931 & 5 \\
\hline
\end{tabular}




\begin{tabular}{|c|c|c|c|c|c|c|c|}
\hline 24 & $\begin{array}{l}\text { A-kinase anchor protein } 2 \text { - } \\
\text { Mus musculus (Mouse) }\end{array}$ & 203 & 34 & 99089.83 & AKAP2_MOUSE & & \\
\hline 25 & $\begin{array}{l}\text { A-kinase anchor protein } 2 \text { - } \\
\text { Mus musculus (Mouse) }\end{array}$ & 154 & 24 & 99089.83 & AKAP2_MOUSE & & \\
\hline 26 & $\begin{array}{c}\text { A-kinase anchor protein } 2 \text { - } \\
\text { Mus musculus (Mouse) }\end{array}$ & 139 & 25 & 99089.83 & AKAP2_MOUSE & & \\
\hline 27 & $\begin{array}{c}\text { A-kinase anchor protein } 2 \text { - } \\
\text { Mus musculus (Mouse) }\end{array}$ & 129 & 20 & 99089.83 & AKAP2_MOUSE & & \\
\hline 28 & $\begin{array}{l}\text { Aldh1a3 protein - Mus } \\
\text { musculus (Mouse) }\end{array}$ & 34 & 28 & 18949.69 & Q810V9_MOUSE & & \\
\hline 29 & $\begin{array}{l}\text { Aldh1a3 protein - Mus } \\
\text { musculus (Mouse) }\end{array}$ & 37 & 28 & 18949.69 & Q810V9_MOUSE & & \\
\hline 30 & $\begin{array}{l}\text { Aldh1a3 protein - Mus } \\
\text { musculus (Mouse) }\end{array}$ & 38 & 28 & 18949.69 & Q810V9_MOUSE & & \\
\hline 31 & $\begin{array}{l}\text { Aldh1a3 protein - Mus } \\
\text { musculus (Mouse) }\end{array}$ & 30 & 28 & 18949.69 & Q810V9_MOUSE & & \\
\hline 32 & $\begin{array}{l}\text { Aldh1a3 protein - Mus } \\
\text { musculus (Mouse) }\end{array}$ & 32 & 28 & 18949.69 & Q810V9_MOUSE & & \\
\hline 33 & $\begin{array}{l}\text { Aldh1a3 protein - Mus } \\
\text { musculus (Mouse) }\end{array}$ & 31 & 28 & 18949.69 & Q810V9_MOUSE & & \\
\hline 34 & $\begin{array}{l}\text { Aldh1a3 protein - Mus } \\
\text { musculus (Mouse) }\end{array}$ & 30 & 28 & 18949.69 & Q810V9_MOUSE & & \\
\hline 35 & $\begin{array}{l}\text { Aldh1a3 protein - Mus } \\
\text { musculus (Mouse) }\end{array}$ & 27 & 28 & 18949.69 & Q810V9_MOUSE & & \\
\hline 36 & $\begin{array}{l}\text { Aldh1a3 protein - Mus } \\
\text { musculus (Mouse) }\end{array}$ & 32 & 28 & 18949.69 & Q810V9_MOUSE & & \\
\hline 37 & $\begin{array}{l}\text { Aldh1a3 protein - Mus } \\
\text { musculus (Mouse) }\end{array}$ & 39 & 30 & 18949.69 & Q810V9_MOUSE & & \\
\hline 38 & $\begin{array}{l}\text { Aldh1a3 protein - Mus } \\
\text { musculus (Mouse) }\end{array}$ & 39 & 30 & 18949.69 & Q810V9_MOUSE & & \\
\hline 39 & $\begin{array}{l}\text { Aldh1a3 protein - Mus } \\
\text { musculus (Mouse) }\end{array}$ & 37 & 28 & 18949.69 & Q810V9_MOUSE & & \\
\hline 40 & $\begin{array}{l}\text { Aldh1a3 protein - Mus } \\
\text { musculus (Mouse) }\end{array}$ & 38 & 33 & 18949.69 & Q810V9_MOUSE & & \\
\hline 41 & $\begin{array}{l}\text { Aldh1a3 protein - Mus } \\
\text { musculus (Mouse) }\end{array}$ & 32 & 28 & 18949.69 & Q810V9_MOUSE & & \\
\hline 42 & $\begin{array}{l}\text { Alpha-enolase - Mus } \\
\text { musculus (Mouse) }\end{array}$ & 147 & 41 & 47453.34 & ENOA_MOUSE & \multirow{2}{*}{ P17182 } & \multirow{2}{*}{6} \\
\hline 43 & $\begin{array}{l}\text { Alpha-enolase - Mus } \\
\text { musculus (Mouse) }\end{array}$ & 65 & 23 & 47453.34 & ENOA_MOUSE & & \\
\hline 44 & $\begin{array}{l}\text { Annexin A2 - Mus musculus } \\
\text { (Mouse) }\end{array}$ & 151 & 48 & 38936.95 & ANXA2_MOUSE & \multirow{5}{*}{ P07356 } & \multirow{5}{*}{7} \\
\hline 45 & $\begin{array}{l}\text { Annexin A2 - Mus musculus } \\
\text { (Mouse) }\end{array}$ & 127 & 46 & 38936.95 & ANXA2_MOUSE & & \\
\hline 46 & $\begin{array}{l}\text { Annexin A2 - Mus musculus } \\
\text { (Mouse) }\end{array}$ & 154 & 46 & 38936.95 & ANXA2_MOUSE & & \\
\hline 47 & $\begin{array}{l}\text { Annexin A2 - Mus musculus } \\
\text { (Mouse) }\end{array}$ & 134 & 47 & 38936.95 & ANXA2_MOUSE & & \\
\hline 48 & $\begin{array}{c}\text { Annexin A2 - Mus musculus } \\
\text { (Mouse) }\end{array}$ & 164 & 52 & 38936.95 & ANXA2_MOUSE & & \\
\hline 49 & $\begin{array}{c}\text { Caldesmon } 1 \text { - Mus musculus } \\
\text { (Mouse) }\end{array}$ & 67 & 20 & 60530.80 & Q8VCQ8_MOUSE & \multirow{2}{*}{ Q8VCQ8 } & \multirow{2}{*}{8} \\
\hline 50 & $\begin{array}{c}\text { Caldesmon } 1 \text { - Mus musculus } \\
\text { (Mouse) }\end{array}$ & 114 & 23 & 60530.80 & Q8VCQ8_MOUSE & & \\
\hline
\end{tabular}




\begin{tabular}{|c|c|c|c|c|c|c|c|}
\hline 51 & $\begin{array}{c}\text { Caldesmon } 1 \text { - Mus musculus } \\
\text { (Mouse) }\end{array}$ & 101 & 19 & 60530.80 & Q8VCQ8_MOUSE & & \\
\hline 52 & $\begin{array}{c}\text { Calpastatin - Mus musculus } \\
\text { (Mouse) }\end{array}$ & 74 & 17 & 85098.73 & ICAL_MOUSE & \multirow{2}{*}{ P51125 } & \multirow{2}{*}{9} \\
\hline 53 & $\begin{array}{c}\text { Calpastatin - Mus musculus } \\
\text { (Mouse) }\end{array}$ & 161 & 31 & 85098.73 & ICAL_MOUSE & & \\
\hline 54 & $\begin{array}{c}\text { Calponin-2 - Mus musculus } \\
\text { (Mouse) }\end{array}$ & 62 & 27 & 33590.21 & CNN2_MOUSE & \multirow{4}{*}{ Q08093 } & \multirow{4}{*}{10} \\
\hline 55 & $\begin{array}{c}\text { Calponin-2 - Mus musculus } \\
\text { (Mouse) }\end{array}$ & 105 & 49 & 33590.21 & CNN2_MOUSE & & \\
\hline 56 & $\begin{array}{c}\text { Calponin-2 - Mus musculus } \\
\text { (Mouse) }\end{array}$ & 63 & 41 & 33590.21 & CNN2_MOUSE & & \\
\hline 57 & $\begin{array}{l}\text { Calponin-2 - Mus musculus } \\
\text { (Mouse) }\end{array}$ & 79 & 41 & 33590.21 & CNN2_MOUSE & & \\
\hline 58 & $\begin{array}{c}\text { Calponin-3 - Mus musculus } \\
\text { (Mouse) }\end{array}$ & 113 & 39 & 36576.90 & CNN3_MOUSE & \multirow{3}{*}{ Q9DAW9 } & \multirow{3}{*}{11} \\
\hline 59 & $\begin{array}{c}\text { Calponin-3 - Mus musculus } \\
\text { (Mouse) }\end{array}$ & 96 & 35 & 36576.90 & CNN3_MOUSE & & \\
\hline 60 & $\begin{array}{c}\text { Calponin-3 - Mus musculus } \\
\text { (Mouse) }\end{array}$ & 59 & 21 & 36576.90 & CNN3_MOUSE & & \\
\hline 61 & $\begin{array}{l}\text { Capping protein - Mus } \\
\text { musculus (Mouse) }\end{array}$ & 61 & 19 & 39029.78 & Q99LB4_MOUSE & & \\
\hline 62 & $\begin{array}{c}\text { Carbonyl reductase } 3 \text { - Mus } \\
\text { musculus (Mouse) }\end{array}$ & 78 & 33 & 31333.07 & Q8K354_MOUSE & Q8K354 & 12 \\
\hline 63 & $\begin{array}{c}\text { Cellular nucleic acid-binding } \\
\text { protein - Mus musculus } \\
\text { (Mouse) }\end{array}$ & 67 & & 20833.08 & CNBP_MOUSE & \multirow{2}{*}{ P53996 } & \multirow{2}{*}{13} \\
\hline 64 & $\begin{array}{c}\text { Cellular nucleic acid-binding } \\
\text { protein - Mus musculus } \\
\text { (Mouse) }\end{array}$ & 62 & 33 & 20833.08 & CNBP_MOUSE & & \\
\hline 65 & $\begin{array}{l}\text { Clathrin light polypeptide - } \\
\text { Mus musculus (Mouse) }\end{array}$ & 29 & 17 & 23521.36 & A2AJ56_MOUSE & & \\
\hline 66 & $\begin{array}{l}\text { Cofilin-1 - Mus musculus } \\
\text { (Mouse) }\end{array}$ & 138 & 65 & 18775.76 & COF1_MOUSE & \multirow{4}{*}{ P18760 } & \multirow{4}{*}{14} \\
\hline 67 & $\begin{array}{c}\text { Cofilin-1 - Mus musculus } \\
\text { (Mouse) }\end{array}$ & 87 & 48 & 18775.76 & COF1_MOUSE & & \\
\hline 68 & $\begin{array}{c}\text { Cofilin-1 - Mus musculus } \\
\text { (Mouse) }\end{array}$ & 107 & 48 & 18775.76 & COF1_MOUSE & & \\
\hline 69 & $\begin{array}{c}\text { Cofilin-1 - Mus musculus } \\
\text { (Mouse) }\end{array}$ & 73 & 26 & 18775.76 & COF1_MOUSE & & \\
\hline 70 & $\begin{array}{l}\text { CRL-1722 L5178Y-R cDNA, } \\
\text { RIKEN full-length enriched } \\
\text { library, clone:I730098K12 } \\
\text { product:deoxynucleotid }\end{array}$ & 28 & 15 & 37056.85 & Q3THA4_MOUSE & & \\
\hline 71 & $\begin{array}{c}\text { Destrin - Mus musculus } \\
\text { (Mouse) }\end{array}$ & 68 & 32 & 18851.61 & DEST_MOUSE & \multirow{2}{*}{ Q9R0P5 } & \multirow{2}{*}{15} \\
\hline 72 & $\begin{array}{c}\text { Destrin - Mus musculus } \\
\text { (Mouse) }\end{array}$ & 59 & 35 & 18851.61 & DEST_MOUSE & & \\
\hline 73 & $\begin{array}{c}\text { Dihydropyrimidinase-related } \\
\text { protein } 2 \text { - Mus musculus } \\
\text { (Mouse) }\end{array}$ & 159 & 35 & 62637.74 & DPYL2_MOUSE & \multirow{3}{*}{ O08553 } & \multirow{3}{*}{16} \\
\hline 74 & $\begin{array}{c}\text { Dihydropyrimidinase-related } \\
\text { protein } 2 \text { - Mus musculus } \\
\text { (Mouse) }\end{array}$ & 204 & 48 & 62637.74 & DPYL2_MOUSE & & \\
\hline 75 & Dihydropyrimidinase-related & 85 & 39 & 62637.74 & DPYL2_MOUSE & & \\
\hline
\end{tabular}




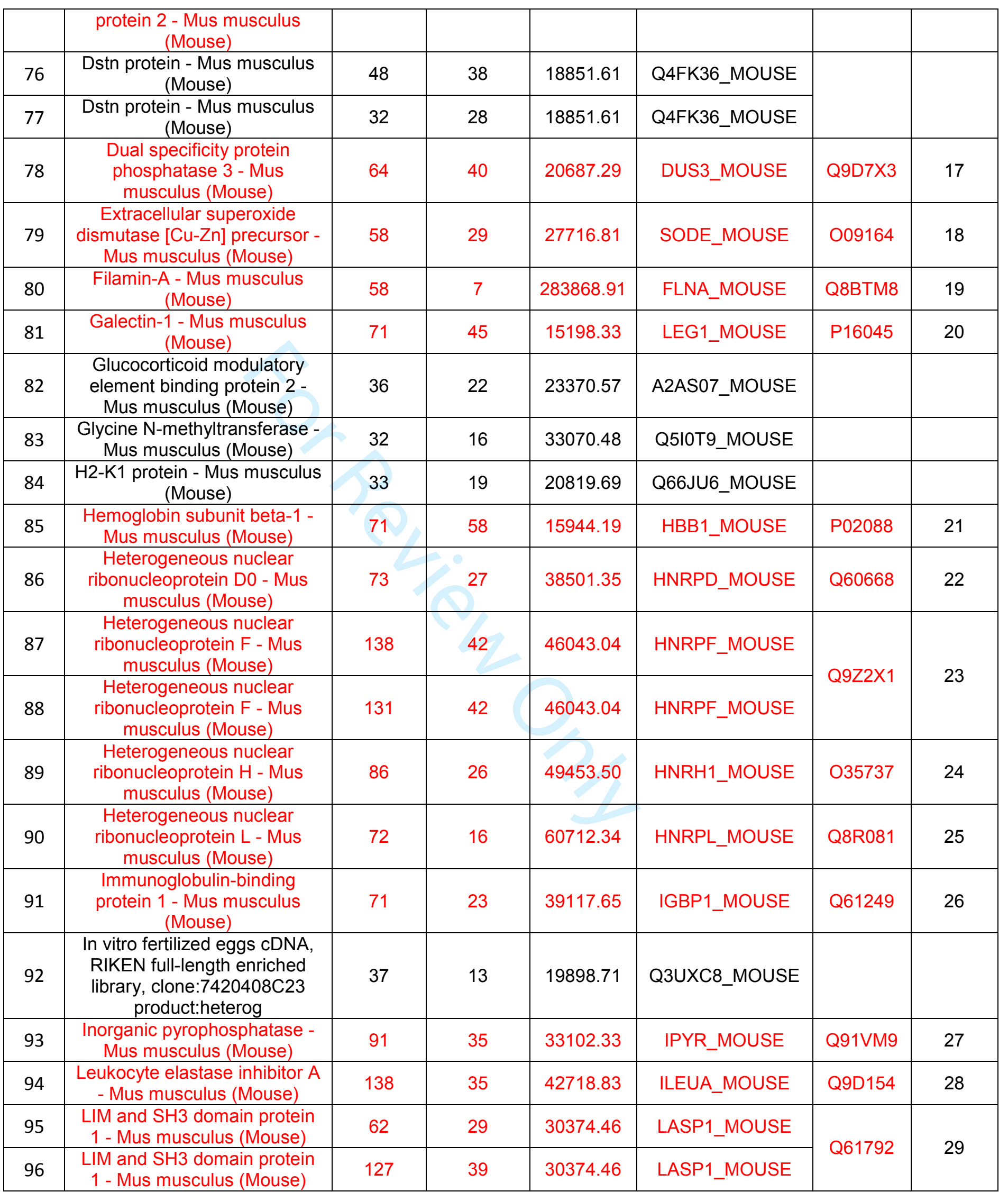




\begin{tabular}{|c|c|c|c|c|c|c|c|}
\hline 97 & $\begin{array}{c}\text { Lymphocyte-specific protein } 1 \\
\text { - Mus musculus (Mouse) }\end{array}$ & 106 & 48 & 36805.87 & LSP1_MOUSE & & 30 \\
\hline 98 & $\begin{array}{l}\text { Melanocyte cDNA, RIKEN } \\
\text { full-length enriched library, } \\
\text { clone:G270138C06 } \\
\text { product:caldesmon 1, full ins }\end{array}$ & 36 & 15 & 44189.84 & Q3UGC3_MOUSE & & \\
\hline 99 & $\begin{array}{l}\text { MFLJ00400 protein - Mus } \\
\text { musculus (Mouse) }\end{array}$ & 28 & 4 & 68989.33 & Q571H8_MOUSE & & \\
\hline 100 & $\begin{array}{l}\text { Mszf77 - Mus musculus } \\
\text { (Mouse) }\end{array}$ & 33 & 62 & 3417.61 & O88227_MOUSE & & \\
\hline 101 & $\begin{array}{l}\text { Myl6 protein - Mus musculus } \\
\text { (Mouse) }\end{array}$ & 55 & 22 & 17121.20 & Q642K0_MOUSE & & \\
\hline 102 & $\begin{array}{c}\text { Myosin regulatory light chain } \\
2 \text {, atrial isoform - Mus } \\
\text { musculus (Mouse) }\end{array}$ & 76 & 55 & 19608.63 & MLRA_MOUSE & Q9QVP4 & 31 \\
\hline 103 & $\begin{array}{c}\text { Myosin, heavy polypeptide 1, } \\
\text { skeletal muscle, adult - Mus } \\
\text { musculus (Mouse) }\end{array}$ & 29 & 4 & 224115.73 & Q32P18_MOUSE & & \\
\hline 104 & $\begin{array}{c}\mathrm{Na}(+) / \mathrm{H}(+) \text { exchange } \\
\text { regulatory cofactor NHE-RF2 } \\
\text { - Mus musculus (Mouse) }\end{array}$ & 96 & 32 & 37721.99 & NHRF2_MOUSE & \multirow{6}{*}{ Q9JHL1 } & \multirow{6}{*}{32} \\
\hline 105 & $\begin{array}{c}\mathrm{Na}(+) / \mathrm{H}(+) \text { exchange } \\
\text { regulatory cofactor NHE-RF2 } \\
\text { - Mus musculus (Mouse) }\end{array}$ & 173 & 43 & 37721.99 & NHRF2_MOUSE & & \\
\hline 106 & $\begin{array}{l}\mathrm{Na}(+) / \mathrm{H}(+) \text { exchange } \\
\text { regulatory cofactor NHE-RF2 } \\
\text { - Mus musculus (Mouse) }\end{array}$ & 214 & & 37721.99 & NHRF2_MOUSE & & \\
\hline 107 & $\begin{array}{c}\mathrm{Na}(+) / \mathrm{H}(+) \text { exchange } \\
\text { regulatory cofactor NHE-RF2 } \\
\text { - Mus musculus (Mouse) }\end{array}$ & 269 & 66 & 37721.99 & NHRF2_MOUSE & & \\
\hline 108 & $\begin{array}{c}\mathrm{Na}(+) / \mathrm{H}(+) \text { exchange } \\
\text { regulatory cofactor NHE-RF2 } \\
\text { - Mus musculus (Mouse) }\end{array}$ & 244 & 61 & 37721.99 & NHRF2_MOUSE & & \\
\hline 109 & $\begin{array}{c}\mathrm{Na}(+) / \mathrm{H}(+) \text { exchange } \\
\text { regulatory cofactor NHE-RF2 } \\
\text { - Mus musculus (Mouse) }\end{array}$ & 174 & 49 & 37721.99 & NHRF2_MOUSE & & \\
\hline 110 & $\begin{array}{c}\text { Novel protein putative } \\
\text { orthologue to human } \\
\text { mitochondrial carrier triple } \\
\text { repeat } 6 \text { - Mus musculus (Mo }\end{array}$ & 28 & 21 & 21020.77 & A2AF35_MOUSE & & \\
\hline 111 & $\begin{array}{l}\text { Nucleoredoxin - Mus } \\
\text { musculus (Mouse) }\end{array}$ & 38 & 82 & 3538.83 & Q5H8T6_MOUSE & & \\
\hline 112 & $\begin{array}{l}\text { Osteoclast-like cell cDNA, } \\
\text { RIKEN full-length enriched } \\
\text { library, clone:I420020N05 } \\
\text { product:clathrin, I }\end{array}$ & 53 & 16 & 23274.25 & Q3TWZ9_MOUSE & & \\
\hline 113 & $\begin{array}{l}\text { Peroxiredoxin } 1 \text { - Mus } \\
\text { musculus (Mouse) }\end{array}$ & 36 & 22 & 22390.44 & A2AP16_MOUSE & & \\
\hline 114 & $\begin{array}{l}\text { Peroxiredoxin-1 - Mus } \\
\text { musculus (Mouse) }\end{array}$ & 145 & 57 & 22390.44 & PRDX1_MOUSE & & \\
\hline 115 & $\begin{array}{l}\text { Peroxiredoxin-1 - Mus } \\
\text { musculus (Mouse) }\end{array}$ & 75 & 49 & 22390.44 & PRDX1_MOUSE & \multirow{3}{*}{ P35700 } & \multirow{3}{*}{33} \\
\hline 116 & $\begin{array}{l}\text { Peroxiredoxin-1 - Mus } \\
\text { musculus (Mouse) }\end{array}$ & 158 & 63 & 22390.44 & PRDX1_MOUSE & & \\
\hline 117 & Peroxiredoxin-1 - Mus & 96 & 44 & 22390.44 & PRDX1_MOUSE & & \\
\hline
\end{tabular}




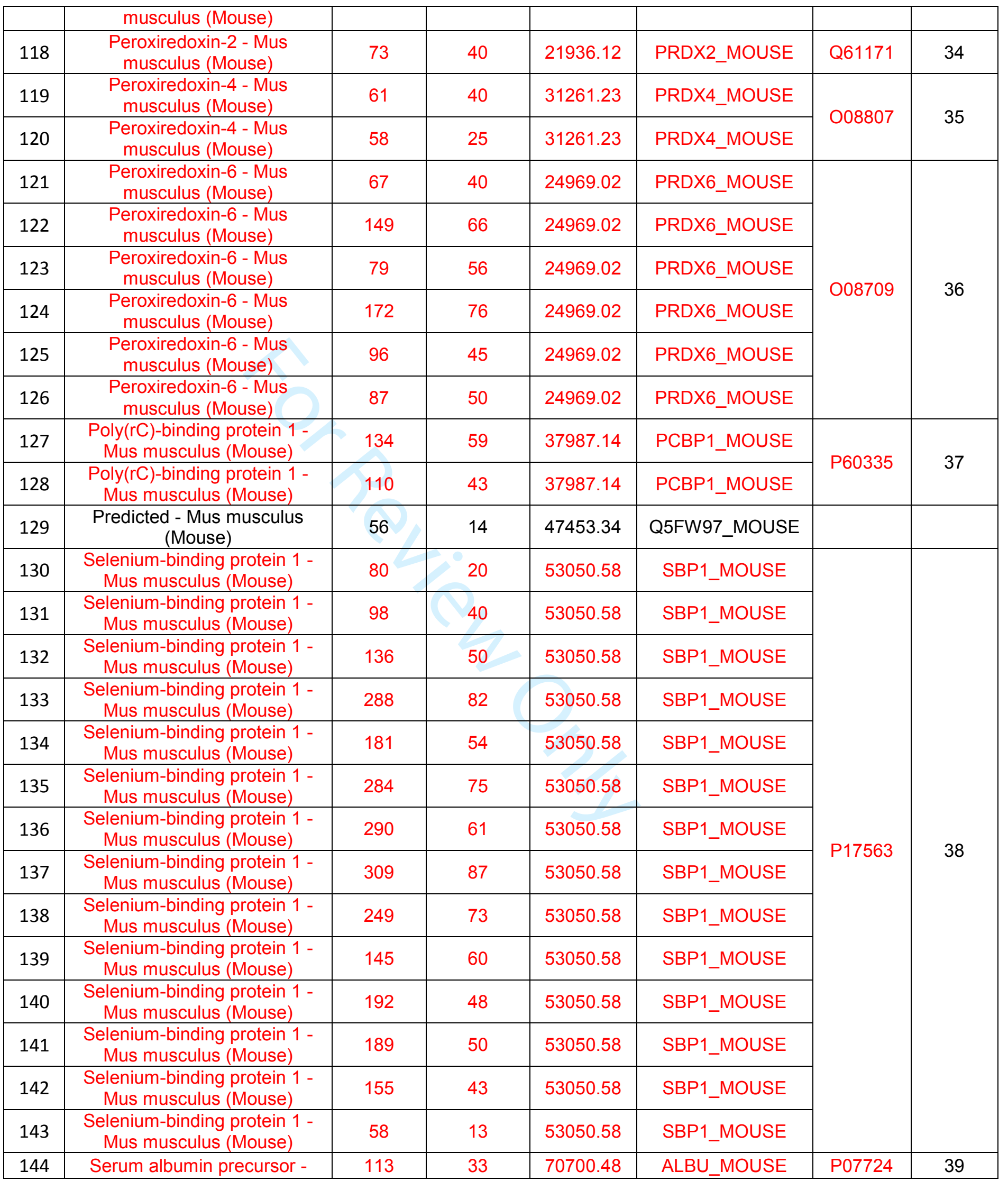




\begin{tabular}{|c|c|c|c|c|c|c|c|}
\hline & Mus musculus (Mouse) & & & & & & \\
\hline 145 & $\begin{array}{l}\text { Serum albumin precursor - } \\
\text { Mus musculus (Mouse) }\end{array}$ & 78 & 23 & 70700.48 & ALBU_MOUSE & & \\
\hline 146 & $\begin{array}{l}\text { Serum albumin precursor - } \\
\text { Mus musculus (Mouse) }\end{array}$ & 225 & 46 & 70700.48 & ALBU_MOUSE & & \\
\hline 147 & $\begin{array}{l}\text { Serum albumin precursor - } \\
\text { Mus musculus (Mouse) }\end{array}$ & 221 & 42 & 70700.48 & ALBU_MOUSE & & \\
\hline 148 & $\begin{array}{l}\text { Serum albumin precursor - } \\
\text { Mus musculus (Mouse) }\end{array}$ & 113 & 25 & 70700.48 & ALBU_MOUSE & & \\
\hline 149 & $\begin{array}{l}\text { Serum albumin precursor - } \\
\text { Mus musculus (Mouse) }\end{array}$ & 255 & 52 & 70700.48 & ALBU_MOUSE & & \\
\hline 150 & $\begin{array}{l}\text { Serum albumin precursor - } \\
\text { Mus musculus (Mouse) }\end{array}$ & 170 & 43 & 70700.48 & ALBU_MOUSE & & \\
\hline 151 & $\begin{array}{c}\text { Src substrate cortactin - Mus } \\
\text { musculus (Mouse) }\end{array}$ & 219 & 43 & 61393.52 & SRC8_MOUSE & \multirow{2}{*}{ Q60598 } & \multirow{2}{*}{40} \\
\hline 152 & $\begin{array}{c}\text { Src substrate cortactin - Mus } \\
\text { musculus (Mouse) }\end{array}$ & 63 & 18 & 61393.52 & SRC8_MOUSE & & \\
\hline 153 & $\begin{array}{c}\text { Stress-induced- } \\
\text { phosphoprotein } 1 \text { - Mus } \\
\text { musculus (Mouse) }\end{array}$ & 97 & 32 & 63169.63 & STIP1_MOUSE & Q60864 & 41 \\
\hline 154 & $\begin{array}{l}\text { Synapse-associated protein } 1 \\
\text { - Mus musculus (Mouse) }\end{array}$ & 67 & 17 & 41381.51 & SYAP1_MOUSE & Q9D5V6 & 42 \\
\hline 155 & $\begin{array}{c}\text { Talin-1 - Mus musculus } \\
\text { (Mouse) }\end{array}$ & 114 & 17 & 271831.92 & TLN1_MOUSE & P26039 & 43 \\
\hline 156 & $\begin{array}{c}\text { Thioredoxin } 1 \text { - Mus musculus } \\
\text { (Mouse) }\end{array}$ & 44 & 42 & 12009.77 & A2AV97_MOUSE & & \\
\hline 157 & $\begin{array}{c}\text { Uncharacterized protein } \\
\text { C1orf198 homolog - Mus } \\
\text { musculus (Mouse) }\end{array}$ & 95 & 31 & 35408.68 & CA198_MOUSE & Q8C3W1 & 44 \\
\hline 158 & $\begin{array}{c}\text { Uridine phosphorylase } 2 \text { - } \\
\text { Mus musculus (Mouse) }\end{array}$ & 30 & 14 & 36623.21 & A2AIG1_MOUSE & & \\
\hline 159 & $\begin{array}{c}\text { Vigilin - Mus musculus } \\
\text { (Mouse) }\end{array}$ & 64 & 8 & 142225.48 & VIGLN_MOUSE & Q8VDJ3 & 45 \\
\hline 160 & $\begin{array}{c}\text { Vimentin - Mus musculus } \\
\text { (Mouse) }\end{array}$ & 111 & 42 & 53712.08 & VIME_MOUSE & P20152 & 46 \\
\hline 161 & $\begin{array}{c}\text { Zinc finger protein } 248 \text { - Mus } \\
\text { musculus (Mouse) }\end{array}$ & 36 & 10 & 68338.20 & Q640N4_MOUSE & & \\
\hline 162 & $\begin{array}{c}\text { Zinc finger protein } 248 \text { - Mus } \\
\text { musculus (Mouse) }\end{array}$ & 41 & 13 & 68338.20 & Q640N4_MOUSE & & \\
\hline
\end{tabular}

Table 1.3: mass spec analysis of a 2D gel, of an acid-eluted fraction from lysate 1 derived from mouse skeletal muscles.

\begin{tabular}{|c|c|c|c|c|c|c|c|}
\hline $\begin{array}{c}\text { Spot } \\
\#\end{array}$ & Protein species & $\begin{array}{c}\text { Mascot } \\
\text { Score }\end{array}$ & $\begin{array}{c}\text { \% } \\
\text { Coverage }\end{array}$ & $\begin{array}{c}\text { Protein } \\
\text { MW }\end{array}$ & Accession & $\begin{array}{c}\text { Uniprot } \\
\text { ID }\end{array}$ & $\begin{array}{c}\text { \# of } \\
\text { species }\end{array}$ \\
\hline 1 & $\begin{array}{c}\text { 10 days neonate cerebellum } \\
\text { CDNA, RIKEN full-length } \\
\text { enriched library, } \\
\text { clone:6530402D11 } \\
\text { product:hypot }\end{array}$ & 30 & 25 & 12035.14 & Q8C5H4_MOUSE & & \\
\hline 2 & $\begin{array}{c}13 \text { days embryo male testis } \\
\text { cDNA, RIKEN full-length }\end{array}$ & 37 & 15 & 40784.43 & Q8CD30_MOUSE & & \\
\hline
\end{tabular}




\begin{tabular}{|c|c|c|c|c|c|c|c|}
\hline & $\begin{array}{l}\text { enriched library, } \\
\text { clone:6030456D20 } \\
\text { product:heat }\end{array}$ & & & & & & \\
\hline 3 & $\begin{array}{c}14 \text { days embryo liver cDNA, } \\
\text { RIKEN full-length enriched } \\
\text { library, clone:4432406E13 } \\
\text { product:zinc finger }\end{array}$ & 41 & 70 & 2544.24 & Q8CEE9_MOUSE & & \\
\hline 4 & $\begin{array}{l}15 \text { days embryo head cDNA, } \\
\text { RIKEN full-length enriched } \\
\text { library, clone:D930027M19 } \\
\text { product:NUCLEOPORIN }\end{array}$ & 34 & 7 & 89621.14 & Q8BUA6_MOUSE & & \\
\hline 5 & $\begin{array}{l}16 \text { days embryo head cDNA, } \\
\text { RIKEN full-length enriched } \\
\text { library, clone:C } 130026010 \\
\text { product:weakly simil }\end{array}$ & 44 & 37 & 11570.81 & Q8C4P8_MOUSE & & \\
\hline 6 & $\begin{array}{c}16 \text { days neonate cerebellum } \\
\text { cDNA, RIKEN full-length } \\
\text { enriched library, } \\
\text { clone: } 9630059 \mathrm{H} 04 \\
\text { product:neure }\end{array}$ & 27 & 14 & 17873.27 & Q3V3R0_MOUSE & & \\
\hline 7 & $\begin{array}{l}\text { 18-day embryo whole body } \\
\text { cDNA, RIKEN full-length } \\
\text { enriched library, } \\
\text { clone:1110036D22 } \\
\text { product:hypothe }\end{array}$ & 46 & 26 & 41740.31 & Q9D102_MOUSE & & \\
\hline 8 & $\begin{array}{l}\text { 18-day embryo whole body } \\
\text { cDNA, RIKEN full-length } \\
\text { enriched library, } \\
\text { clone: } 1110029 E 05 \\
\text { product:thiosul }\end{array}$ & 34 & 13 & 33672.90 & Q545S0_MOUSE & & \\
\hline 9 & $\begin{array}{c}\text { 9830124H08Rik protein - Mus } \\
\text { musculus (Mouse) }\end{array}$ & 41 & 24 & 27961.68 & Q6PDL1_MOUSE & & \\
\hline 10 & $\begin{array}{c}\text { Actin, alpha cardiac muscle } 1 \text { - } \\
\text { Mus musculus (Mouse) }\end{array}$ & 75 & 23 & 42334.01 & ACTC_MOUSE & \multirow{2}{*}{ P68033 } & \multirow{2}{*}{1} \\
\hline 11 & $\begin{array}{c}\text { Actin, alpha cardiac muscle } 1 \text { - } \\
\text { Mus musculus (Mouse) }\end{array}$ & 65 & 23 & 42334.01 & ACTC_MOUSE & & \\
\hline 12 & $\begin{array}{l}\text { Actin, alpha skeletal muscle - } \\
\text { Mus musculus (Mouse) }\end{array}$ & 125 & 46 & 42365.98 & ACTS_MOUSE & P68134 & 2 \\
\hline 13 & $\begin{array}{l}\text { Actin, aortic smooth muscle - } \\
\text { Mus musculus (Mouse) }\end{array}$ & 61 & 15 & 42380.96 & ACTA_MOUSE & P62737 & 3 \\
\hline 14 & $\begin{array}{l}\text { Activated spleen cDNA, } \\
\text { RIKEN full-length enriched } \\
\text { library, clone:F830207J03 } \\
\text { product:yes-associated }\end{array}$ & 37 & 27 & 25090.58 & Q3U046_MOUSE & & \\
\hline 15 & $\begin{array}{l}\text { Activated spleen cDNA, } \\
\text { RIKEN full-length enriched } \\
\text { library, clone:F830207J03 } \\
\text { product:yes-associated }\end{array}$ & 36 & 27 & 25090.58 & Q3U046_MOUSE & & \\
\hline 16 & $\begin{array}{l}\text { Activated spleen cDNA, } \\
\text { RIKEN full-length enriched } \\
\text { library, clone:F830207J03 } \\
\text { product:yes-associated }\end{array}$ & 32 & 27 & 25090.58 & Q3U046_MOUSE & & \\
\hline 17 & $\begin{array}{l}\text { Adult male cerebellum cDNA, } \\
\text { RIKEN full-length enriched } \\
\text { library, clone:1520402A20 }\end{array}$ & 31 & 29 & 18159.84 & Q8CEI4_MOUSE & & \\
\hline
\end{tabular}




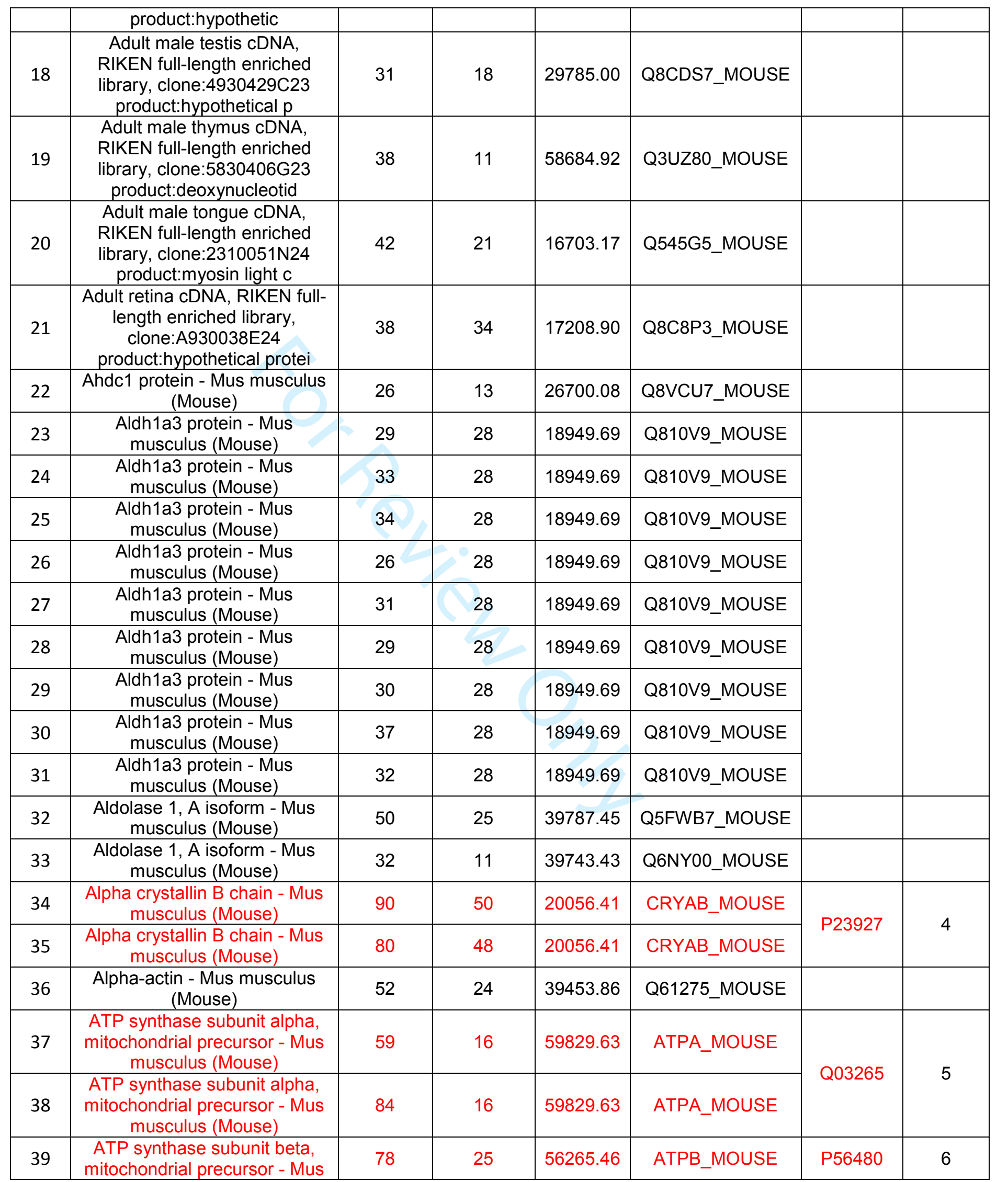




\begin{tabular}{|c|c|c|c|c|c|c|c|}
\hline & musculus (Mouse) & & & & & & \\
\hline 40 & $\begin{array}{l}\text { ATP synthase subunit beta, } \\
\text { mitochondrial precursor - Mus } \\
\text { musculus (Mouse) }\end{array}$ & 60 & 22 & 56265.46 & ATPB_MOUSE & & \\
\hline 41 & $\begin{array}{c}\text { ATP synthase subunit beta, } \\
\text { mitochondrial precursor - Mus } \\
\text { musculus (Mouse) }\end{array}$ & 191 & 42 & 56265.46 & ATPB_MOUSE & & \\
\hline 42 & $\begin{array}{c}\text { Beta-enolase - Mus musculus } \\
\text { (Mouse) }\end{array}$ & 62 & 13 & 47337.43 & ENOB_MOUSE & \multirow{3}{*}{ P21550 } & \multirow{3}{*}{7} \\
\hline 43 & $\begin{array}{c}\text { Beta-enolase - Mus musculus } \\
\text { (Mouse) }\end{array}$ & 103 & 29 & 47337.43 & ENOB_MOUSE & & \\
\hline 44 & $\begin{array}{c}\text { Beta-enolase - Mus musculus } \\
\text { (Mouse) }\end{array}$ & 128 & 30 & 47337.43 & ENOB_MOUSE & & \\
\hline 45 & $\begin{array}{c}\text { Bone marrow macrophage } \\
\text { cDNA, RIKEN full-length } \\
\text { enriched library, } \\
\text { clone:I830036L09 } \\
\text { product:peroxired }\end{array}$ & 36 & 21 & 22358.46 & Q3U9J9_MOUSE & & \\
\hline 46 & $\begin{array}{c}\text { Creatine kinase M-type - Mus } \\
\text { musculus (Mouse) }\end{array}$ & 61 & 25 & 43245.88 & KCRM_MOUSE & P07310 & 8 \\
\hline 47 & $\begin{array}{l}\text { Fructose-bisphosphate } \\
\text { aldolase A - Mus musculus } \\
\text { (Mouse) }\end{array}$ & 70 & 21 & 39787.45 & ALDOA_MOUSE & \multirow{2}{*}{ P05064 } & 9 \\
\hline 48 & $\begin{array}{c}\text { Fructose-bisphosphate } \\
\text { aldolase A - Mus musculus } \\
\text { (Mouse) }\end{array}$ & 108 & 51 & 39787.45 & ALDOA_MOUSE & & \\
\hline 49 & $\begin{array}{l}\text { G patch domain and KOW } \\
\text { motifs - Mus musculus } \\
\text { (Mouse) }\end{array}$ & 32 & 12 & 54083.43 & A2AEU7_MOUSE & & \\
\hline 50 & $\begin{array}{c}\text { Glyceraldehyde-3-phosphate } \\
\text { dehydrogenase - Mus } \\
\text { musculus (Mouse) }\end{array}$ & 90 & 34 & 36072.32 & G3P_MOUSE & \multirow{3}{*}{ P16858 } & \multirow{3}{*}{10} \\
\hline 51 & $\begin{array}{c}\text { Glyceraldehyde-3-phosphate } \\
\text { dehydrogenase - Mus } \\
\text { musculus (Mouse) }\end{array}$ & 93 & 41 & 36072.32 & G3P_MOUSE & & \\
\hline 52 & $\begin{array}{l}\text { Glyceraldehyde-3-phosphate } \\
\text { dehydrogenase - Mus } \\
\text { musculus (Mouse) }\end{array}$ & 96 & 41 & 36072.32 & G3P_MOUSE & & \\
\hline 53 & $\begin{array}{l}\text { Hair keratin acidic } 5 \text { - Mus } \\
\text { musculus (Mouse) }\end{array}$ & 32 & 6 & 48983.58 & Q9Z2T8_MOUSE & & \\
\hline 54 & $\begin{array}{l}\text { Heat-shock protein beta-1 - } \\
\text { Mus musculus (Mouse) }\end{array}$ & 89 & 42 & 23056.74 & HSPB1_MOUSE & P14602 & 11 \\
\hline 55 & $\begin{array}{c}\text { Keratin complex } 1 \text {, acidic, } \\
\text { gene } 10 \text { - Mus musculus } \\
\text { (Mouse) }\end{array}$ & 49 & 16 & 57177.78 & A2A513_MOUSE & & \\
\hline 56 & $\begin{array}{l}\text { LATS2B - Mus musculus } \\
\text { (Mouse) }\end{array}$ & 42 & 20 & 19476.01 & Q8VHE2_MOUSE & & \\
\hline 57 & $\begin{array}{c}\text { L-lactate dehydrogenase A } \\
\text { chain - Mus musculus (Mouse) }\end{array}$ & 87 & 27 & 36817.35 & LDHA_MOUSE & P06151 & 12 \\
\hline 58 & $\begin{array}{l}\text { Low-voltage-activated calcium } \\
\text { channel alpha13.2 subunit - } \\
\text { Mus musculus (Mouse) }\end{array}$ & 31 & 32 & 12283.98 & Q99P43_MOUSE & & \\
\hline 59 & $\begin{array}{c}\text { NADH dehydrogenase } \\
\text { [ubiquinone] flavoprotein } 1 \text {, } \\
\text { mitochondrial precursor - Mus }\end{array}$ & 73 & 14 & 51485.97 & NDUV1_MOUSE & Q91YT0 & 13 \\
\hline
\end{tabular}


Table 1.4: mass spec analysis of a 2D gel of a DTT-eluted fraction from lysate 1 derived from mouse skeletal muscles. The analysis is for the proteins remaining on the affinity column after acidic elution has occurred.

\begin{tabular}{|c|c|c|c|c|c|c|c|}
\hline $\begin{array}{c}\text { Spot } \\
\#\end{array}$ & Protein species & $\begin{array}{c}\text { Mascot } \\
\text { Score }\end{array}$ & $\begin{array}{c}\text { \% } \\
\text { Coverage }\end{array}$ & $\begin{array}{c}\text { Protein } \\
\text { MW }\end{array}$ & Accession & $\begin{array}{c}\text { Uniprot } \\
\text { ID }\end{array}$ & $\begin{array}{c}\text { \# of } \\
\text { species }\end{array}$ \\
\hline 1 & $\begin{array}{c}\text { 18-day embryo whole body } \\
\text { cDNA, RIKEN full-length } \\
\text { enriched library, } \\
\text { clone:1110056B09 } \\
\text { product:weakly }\end{array}$ & 82 & 32 & 24405.14 & Q8BK84_MOUSE & Q8BK84 & 1 \\
\hline 2 & $\begin{array}{c}60 \text { kDa heat shock protein, } \\
\text { mitochondrial precursor - Mus } \\
\text { musculus (Mouse) }\end{array}$ & 59 & 22 & 61088.45 & CH60_MOUSE & P63038 & 2 \\
\hline 3 & $\begin{array}{c}\text { Adenylate kinase isoenzyme 1 } \\
\text { - Mus musculus (Mouse) }\end{array}$ & 68 & 52 & 21640.16 & KAD1_MOUSE & Q9R0Y5 & 3 \\
\hline
\end{tabular}




\begin{tabular}{|c|c|c|c|c|c|c|c|}
\hline 4 & $\begin{array}{l}\text { Adenylate kinase isoenzyme } 1 \\
\text { - Mus musculus (Mouse) }\end{array}$ & 130 & 56 & 21640.16 & KAD1_MOUSE & & \\
\hline 5 & $\begin{array}{l}\text { Aldh1a3 protein - Mus } \\
\text { musculus (Mouse) }\end{array}$ & 28 & 28 & 18949.69 & Q810V9_MOUSE & & \\
\hline 6 & $\begin{array}{l}\text { Aldh1a3 protein - Mus } \\
\text { musculus (Mouse) }\end{array}$ & 37 & 30 & 18949.69 & Q810V9_MOUSE & & \\
\hline 7 & $\begin{array}{c}\text { Carbonic anhydrase } 3 \text { - Mus } \\
\text { musculus (Mouse) }\end{array}$ & 60 & 31 & 29632.75 & CAH3_MOUSE & P16015 & 4 \\
\hline 8 & $\begin{array}{c}\text { Creatine kinase M-type - Mus } \\
\text { musculus (Mouse) }\end{array}$ & 74 & 22 & 43245.88 & KCRM_MOUSE & \multirow{2}{*}{ P07310 } & \multirow{2}{*}{5} \\
\hline 9 & $\begin{array}{c}\text { Creatine kinase M-type - Mus } \\
\text { musculus (Mouse) }\end{array}$ & 120 & 34 & 43245.88 & KCRM_MOUSE & & \\
\hline 10 & $\begin{array}{l}\text { Creatine kinase, sarcomeric } \\
\text { mitochondrial precursor - Mus } \\
\text { musculus (Mouse) }\end{array}$ & 158 & 38 & 47899.49 & KCRS_MOUSE & \multirow{2}{*}{ Q6P8J7 } & \multirow{2}{*}{6} \\
\hline 11 & $\begin{array}{c}\text { Creatine kinase, sarcomeric } \\
\text { mitochondrial precursor - Mus } \\
\text { musculus (Mouse) }\end{array}$ & 156 & 38 & 47899.49 & KCRS_MOUSE & & \\
\hline 12 & $\begin{array}{c}\text { Crip2 protein - Mus musculus } \\
\text { (Mouse) }\end{array}$ & 53 & 40 & 23510.36 & Q4FJU3_MOUSE & & \\
\hline 13 & $\begin{array}{l}\text { Fbxo33 protein - Mus } \\
\text { musculus (Mouse) }\end{array}$ & 37 & 17 & 31480.00 & A0JLR4_MOUSE & & \\
\hline 14 & $\begin{array}{c}\text { Galectin-1 - Mus musculus } \\
\text { (Mouse) }\end{array}$ & 70 & 58 & 15198.33 & LEG1_MOUSE & \multirow{2}{*}{ P16045 } & \multirow{2}{*}{7} \\
\hline 15 & $\begin{array}{l}\text { Galectin-1 - Mus musculus } \\
\text { (Mouse) }\end{array}$ & 65 & 45 & 15198.33 & LEG1_MOUSE & & \\
\hline 16 & $\begin{array}{c}\text { Glyceraldehyde-3-phosphate } \\
\text { dehydrogenase - Mus } \\
\text { musculus (Mouse) }\end{array}$ & 93 & 48 & 36072.32 & G3P_MOUSE & \multirow{10}{*}{ P16858 } & \multirow{10}{*}{8} \\
\hline 17 & $\begin{array}{l}\text { Glyceraldehyde-3-phosphate } \\
\text { dehydrogenase - Mus } \\
\text { musculus (Mouse) }\end{array}$ & 98 & 51 & 36072.32 & G3P_MOUSE & & \\
\hline 18 & $\begin{array}{l}\text { Glyceraldehyde-3-phosphate } \\
\text { dehydrogenase - Mus } \\
\text { musculus (Mouse) }\end{array}$ & 124 & 51 & 36072.32 & G3P_MOUSE & & \\
\hline 19 & $\begin{array}{l}\text { Glyceraldehyde-3-phosphate } \\
\text { dehydrogenase - Mus } \\
\text { musculus (Mouse) }\end{array}$ & 58 & 40 & 36072.32 & G3P_MOUSE & & \\
\hline 20 & $\begin{array}{l}\text { Glyceraldehyde-3-phosphate } \\
\text { dehydrogenase - Mus } \\
\text { musculus (Mouse) }\end{array}$ & 100 & 57 & 36072.32 & G3P_MOUSE & & \\
\hline 21 & $\begin{array}{l}\text { Glyceraldehyde-3-phosphate } \\
\text { dehydrogenase - Mus } \\
\text { musculus (Mouse) }\end{array}$ & 106 & 47 & 36072.32 & G3P_MOUSE & & \\
\hline 22 & $\begin{array}{l}\text { Glyceraldehyde-3-phosphate } \\
\text { dehydrogenase - Mus } \\
\text { musculus (Mouse) }\end{array}$ & 81 & 40 & 36072.32 & G3P_MOUSE & & \\
\hline 23 & $\begin{array}{l}\text { Glyceraldehyde-3-phosphate } \\
\text { dehydrogenase - Mus } \\
\text { musculus (Mouse) }\end{array}$ & 83 & 36 & 36072.32 & G3P_MOUSE & & \\
\hline 24 & $\begin{array}{l}\text { Glyceraldehyde-3-phosphate } \\
\text { dehydrogenase - Mus } \\
\text { musculus (Mouse) }\end{array}$ & 92 & 45 & 36072.32 & G3P_MOUSE & & \\
\hline 25 & $\begin{array}{l}\text { Glyceraldehyde-3-phosphate } \\
\text { dehydrogenase - Mus }\end{array}$ & 74 & 48 & 36072.32 & G3P_MOUSE & & \\
\hline
\end{tabular}




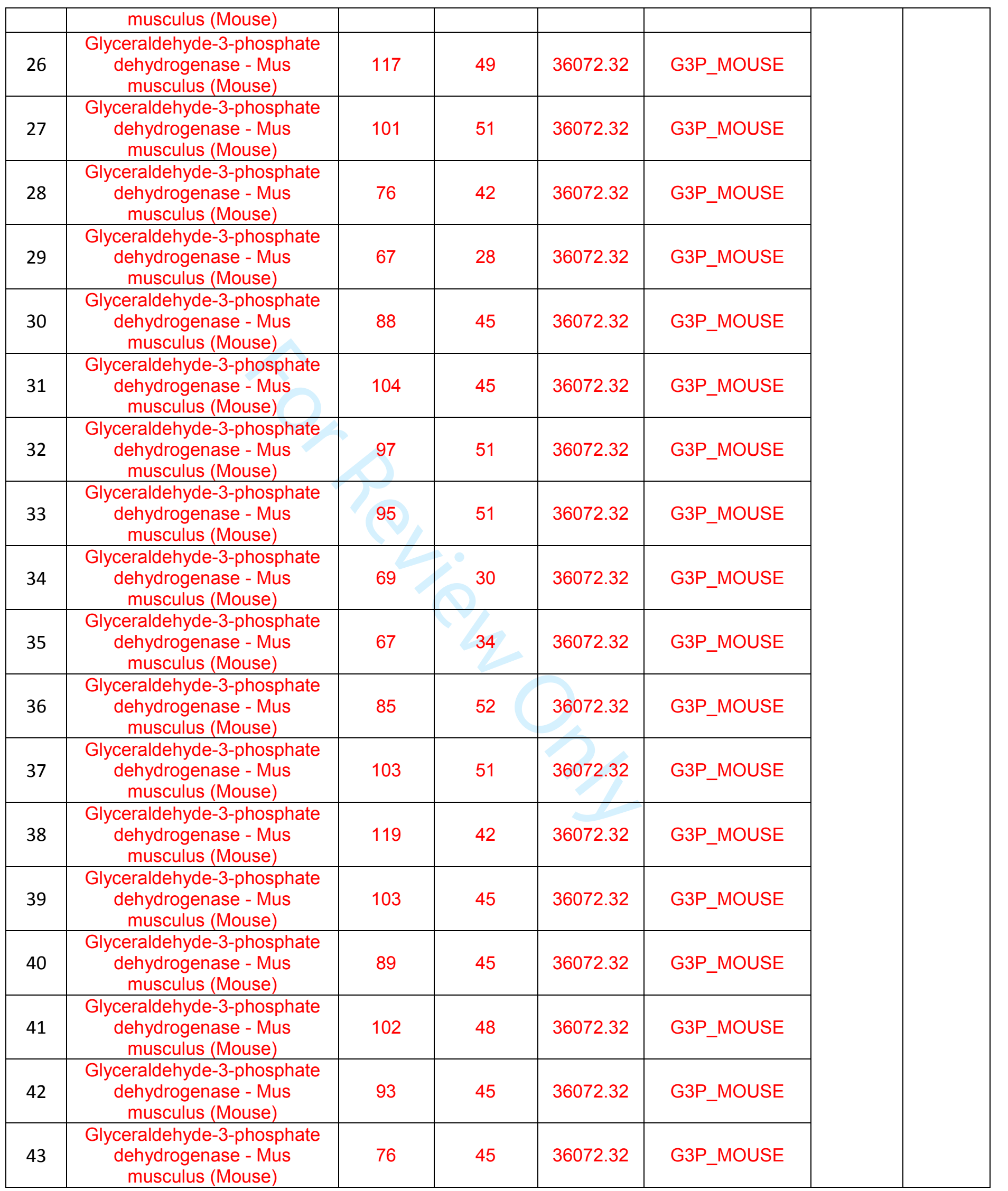




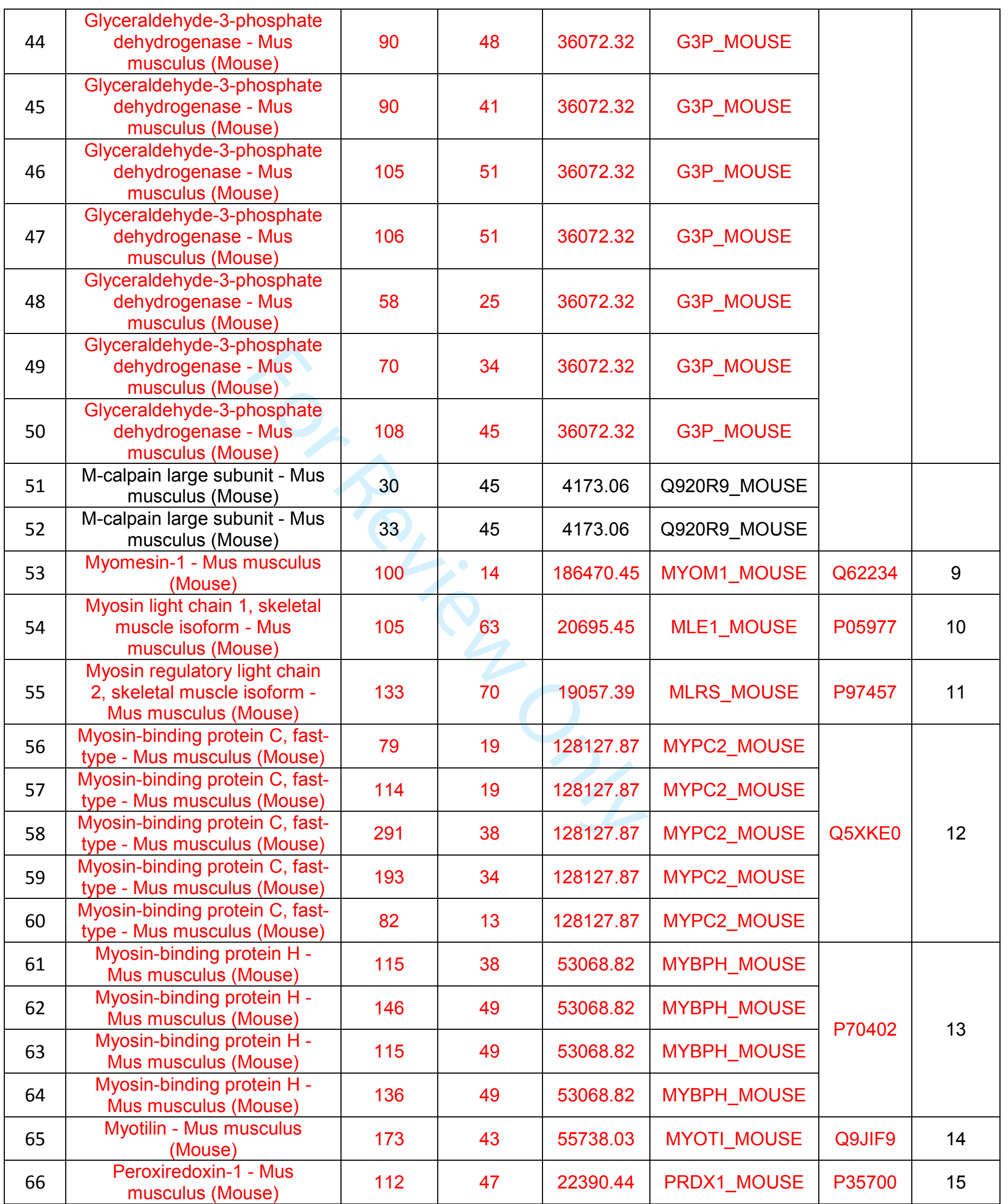




\begin{tabular}{|c|c|c|c|c|c|c|c|}
\hline 67 & $\begin{array}{l}\text { Peroxiredoxin-1 - Mus } \\
\text { musculus (Mouse) }\end{array}$ & 160 & 63 & 22390.44 & PRDX1_MOUSE & & \\
\hline 68 & $\begin{array}{l}\text { Peroxiredoxin-1 - Mus } \\
\text { musculus (Mouse) }\end{array}$ & 83 & 35 & 22390.44 & PRDX1_MOUSE & & \\
\hline 69 & $\begin{array}{l}\text { Peroxiredoxin-1 - Mus } \\
\text { musculus (Mouse) }\end{array}$ & 133 & 58 & 22390.44 & PRDX1_MOUSE & & \\
\hline 70 & $\begin{array}{l}\text { Peroxiredoxin-1 - Mus } \\
\text { musculus (Mouse) }\end{array}$ & 161 & 63 & 22390.44 & PRDX1_MOUSE & & \\
\hline 71 & $\begin{array}{l}\text { Peroxiredoxin-1 - Mus } \\
\text { musculus (Mouse) }\end{array}$ & 165 & 63 & 22390.44 & PRDX1_MOUSE & & \\
\hline 72 & $\begin{array}{l}\text { Peroxiredoxin-1 - Mus } \\
\text { musculus (Mouse) }\end{array}$ & 130 & 53 & 22390.44 & PRDX1_MOUSE & & \\
\hline 73 & $\begin{array}{l}\text { Peroxiredoxin-1 - Mus } \\
\text { musculus (Mouse) }\end{array}$ & 121 & 53 & 22390.44 & PRDX1_MOUSE & & \\
\hline 74 & $\begin{array}{l}\text { Peroxiredoxin-2 - Mus } \\
\text { musculus (Mouse) }\end{array}$ & 95 & 51 & 21936.12 & PRDX2_MOUSE & Q61171 & 16 \\
\hline 75 & $\begin{array}{l}\text { Peroxiredoxin-6 - Mus } \\
\text { musculus (Mouse) }\end{array}$ & 153 & 73 & 24969.02 & PRDX6_MOUSE & \multirow{3}{*}{008709} & \multirow{3}{*}{17} \\
\hline 76 & $\begin{array}{l}\text { Peroxiredoxin- } 6 \text { - Mus } \\
\text { musculus (Mouse) }\end{array}$ & 132 & 57 & 24969.02 & PRDX6_MOUSE & & \\
\hline 77 & $\begin{array}{l}\text { Peroxiredoxin-6 - Mus } \\
\text { musculus (Mouse) }\end{array}$ & 149 & 73 & 24969.02 & PRDX6_MOUSE & & \\
\hline 78 & $\begin{array}{c}\text { Protein DJ-1 - Mus musculus } \\
\text { (Mouse) }\end{array}$ & 88 & 56 & 20236.47 & PARK7_MOUSE & Q99LX0 & 18 \\
\hline 79 & $\begin{array}{c}\text { Thioredoxin-dependent } \\
\text { peroxide reductase, } \\
\text { mitochondrial precursor - Mus } \\
\text { musculus (Mouse) }\end{array}$ & 77 & 36 & 28337.49 & PRDX3_MOUSE & P20108 & 19 \\
\hline
\end{tabular}

Table 1.5: mass spec analysis of a 2D gel of a DTT-eluted fraction from a lysate 2 derived from mouse skeletal muscles. The analysis is for the proteins remaining on the affinity column after acidic elution.

\begin{tabular}{|c|c|c|c|c|c|c|c|}
\hline $\begin{array}{c}\text { Spot } \\
\#\end{array}$ & Protein species & $\begin{array}{l}\text { Mascot } \\
\text { Score }\end{array}$ & $\begin{array}{c}\% \\
\text { Coverage }\end{array}$ & $\begin{array}{l}\text { Protein } \\
\text { MW }\end{array}$ & Accession & $\begin{array}{c}\text { Uniprot } \\
\text { ID }\end{array}$ & $\begin{array}{c}\text { \# of } \\
\text { species }\end{array}$ \\
\hline 1 & $\begin{array}{l}1 \text { cell embryo } 1 \text { cell cDNA, } \\
\text { RIKEN full-length enriched } \\
\text { library, clone:IOC0026C19 } \\
\text { product:hypothetica }\end{array}$ & 32 & 21 & 15783.77 & Q3TLD8_MOUSE & & \\
\hline 2 & $\begin{array}{c}13 \text { days embryo male testis } \\
\text { cDNA, RIKEN full-length } \\
\text { enriched library, } \\
\text { clone:6030400N17 } \\
\text { product:CGMP- }\end{array}$ & 31 & 14 & 32360.93 & Q8BJ62_MOUSE & & \\
\hline 3 & $\begin{array}{c}13 \text { days embryo male testis } \\
\text { cDNA, RIKEN full-length } \\
\text { enriched library, } \\
\text { clone:6030400N17 } \\
\text { product:CGMP- }\end{array}$ & 30 & 14 & 32360.93 & Q8BJ62_MOUSE & & \\
\hline 4 & 15 days embryo head cDNA, & 31 & 22 & 15219.59 & Q3TNY2_MOUSE & & \\
\hline
\end{tabular}




\begin{tabular}{|c|c|c|c|c|c|c|c|}
\hline & $\begin{array}{l}\text { RIKEN full-length enriched } \\
\text { library, clone:D930049J08 } \\
\text { product:spectrin alp }\end{array}$ & & & & & & \\
\hline 5 & $\begin{array}{l}17 \text { days pregnant adult female } \\
\text { amnion cDNA, RIKEN full- } \\
\text { length enriched library, } \\
\text { clone:I920038I15 pro }\end{array}$ & 47 & 12 & 57406.91 & Q3TGS0_MOUSE & & \\
\hline 6 & $\begin{array}{c}\text { 26S proteasome non-ATPase } \\
\text { regulatory subunit } 4 \text { - Mus } \\
\text { musculus (Mouse) }\end{array}$ & 75 & 19 & 40906.24 & PSMD4_MOUSE & O35226 & 1 \\
\hline 7 & $\begin{array}{c}\text { 4833405L16Rik protein - Mus } \\
\text { musculus (Mouse) }\end{array}$ & 33 & 19 & 26899.60 & Q4FZF0_MOUSE & & \\
\hline 8 & $\begin{array}{c}60 \text { kDa heat shock protein, } \\
\text { mitochondrial precursor - Mus } \\
\text { musculus (Mouse) }\end{array}$ & 61 & 21 & 61088.45 & CH60_MOUSE & \multirow{3}{*}{ P63038 } & \multirow{3}{*}{2} \\
\hline 9 & $\begin{array}{c}60 \text { kDa heat shock protein, } \\
\text { mitochondrial precursor - Mus } \\
\text { musculus (Mouse) }\end{array}$ & 131 & 32 & 61088.45 & CH60_MOUSE & & \\
\hline 10 & $\begin{array}{c}60 \text { kDa heat shock protein, } \\
\text { mitochondrial precursor - Mus } \\
\text { musculus (Mouse) }\end{array}$ & 74 & 22 & 61088.45 & CH60_MOUSE & & \\
\hline 11 & $\begin{array}{c}\text { 6-phosphofructokinase, } \\
\text { muscle type - Mus musculus } \\
\text { (Mouse) }\end{array}$ & 71 & 12 & 86069.88 & K6PF_MOUSE & P47857 & 3 \\
\hline 12 & $\begin{array}{c}\text { Aconitate hydratase, } \\
\text { mitochondrial precursor - Mus } \\
\text { musculus (Mouse) }\end{array}$ & 67 & 15 & 86151.30 & ACON_MOUSE & \multirow{7}{*}{ Q99KI0 } & \multirow{7}{*}{4} \\
\hline 13 & $\begin{array}{c}\text { Aconitate hydratase, } \\
\text { mitochondrial precursor - Mus } \\
\text { musculus (Mouse) }\end{array}$ & 108 & 20 & 86151.30 & ACON_MOUSE & & \\
\hline 14 & $\begin{array}{c}\text { Aconitate hydratase, } \\
\text { mitochondrial precursor - Mus } \\
\text { musculus (Mouse) }\end{array}$ & 136 & 27 & 86151.30 & ACON_MOUSE & & \\
\hline 15 & $\begin{array}{c}\text { Aconitate hydratase, } \\
\text { mitochondrial precursor - Mus } \\
\text { musculus (Mouse) }\end{array}$ & 127 & 20 & 86151.30 & ACON_MOUSE & & \\
\hline 16 & $\begin{array}{c}\text { Aconitate hydratase, } \\
\text { mitochondrial precursor - Mus } \\
\text { musculus (Mouse) }\end{array}$ & 130 & 25 & 86151.30 & ACON_MOUSE & & \\
\hline 17 & $\begin{array}{c}\text { Aconitate hydratase, } \\
\text { mitochondrial precursor - Mus } \\
\text { musculus (Mouse) }\end{array}$ & 180 & 40 & 86151.30 & ACON_MOUSE & & \\
\hline 18 & $\begin{array}{c}\text { Aconitate hydratase, } \\
\text { mitochondrial precursor - Mus } \\
\text { musculus (Mouse) }\end{array}$ & 151 & 28 & 86151.30 & ACON_MOUSE & & \\
\hline 19 & $\begin{array}{c}\text { Actin, aortic smooth muscle - } \\
\text { Mus musculus (Mouse) }\end{array}$ & 64 & 15 & 42380.96 & ACTA_MOUSE & P62737 & 5 \\
\hline 20 & $\begin{array}{l}\text { Activated spleen cDNA, } \\
\text { RIKEN full-length enriched } \\
\text { library, clone:F830207J03 } \\
\text { product:yes-associated }\end{array}$ & 32 & 20 & 25090.58 & Q3U046_MOUSE & & \\
\hline 21 & $\begin{array}{l}\text { Adult male testis cDNA, } \\
\text { RIKEN full-length enriched } \\
\text { library, clone:4930512B01 } \\
\text { product:hypothetical p }\end{array}$ & 34 & 41 & 12324.27 & Q9D556_MOUSE & & \\
\hline
\end{tabular}




\begin{tabular}{|c|c|c|c|c|c|c|c|}
\hline 22 & $\begin{array}{l}\text { Aldh1a3 protein - Mus } \\
\text { musculus (Mouse) }\end{array}$ & 30 & 28 & 18949.69 & Q810V9_MOUSE & & \\
\hline 23 & $\begin{array}{l}\text { Aldh1a3 protein - Mus } \\
\text { musculus (Mouse) }\end{array}$ & 30 & 28 & 18949.69 & Q810V9_MOUSE & & \\
\hline 24 & $\begin{array}{l}\text { Aldh1a3 protein - Mus } \\
\text { musculus (Mouse) }\end{array}$ & 35 & 28 & 18949.69 & Q810V9_MOUSE & & \\
\hline 25 & $\begin{array}{l}\text { Aldh1a3 protein - Mus } \\
\text { musculus (Mouse) }\end{array}$ & 35 & 28 & 18949.69 & Q810V9_MOUSE & & \\
\hline 26 & $\begin{array}{l}\text { ATP synthase subunit beta, } \\
\text { mitochondrial precursor - Mus } \\
\text { musculus (Mouse) }\end{array}$ & 167 & 46 & 56265.46 & ATPB_MOUSE & P56480 & 6 \\
\hline 27 & $\begin{array}{c}\text { Beta-enolase - Mus musculus } \\
\text { (Mouse) }\end{array}$ & 93 & 26 & 47337.43 & ENOB_MOUSE & \multirow{3}{*}{ P21550 } & \multirow{3}{*}{7} \\
\hline 28 & $\begin{array}{c}\text { Beta-enolase - Mus musculus } \\
\text { (Mouse) }\end{array}$ & 186 & 61 & 47337.43 & ENOB_MOUSE & & \\
\hline 29 & $\begin{array}{c}\text { Beta-enolase - Mus musculus } \\
\text { (Mouse) }\end{array}$ & 211 & 64 & 47337.43 & ENOB_MOUSE & & \\
\hline 30 & $\begin{array}{c}\text { Beta-taxilin - Mus musculus } \\
\text { (Mouse) }\end{array}$ & 58 & 13 & 77729.63 & TXLNB_MOUSE & Q8VBT1 & 8 \\
\hline 31 & $\begin{array}{c}\text { Bone marrow macrophage } \\
\text { cDNA, RIKEN full-length } \\
\text { enriched library, } \\
\text { clone:I830001B16 } \\
\text { product:vimentin, } \\
\end{array}$ & 62 & 17 & 47204.99 & Q3UD36_MOUSE & & \\
\hline 32 & $\begin{array}{c}\text { CAMP-dependent protein } \\
\text { kinase type I-alpha regulatory } \\
\text { subunit - Mus musculus } \\
\text { (Mouse) }\end{array}$ & 67 & 21 & 43443.14 & KAPO_MOUSE & Q9DBC7 & 9 \\
\hline 33 & $\begin{array}{c}\text { Creatine kinase M-type - Mus } \\
\text { musculus (Mouse) }\end{array}$ & 170 & 53 & 43245.88 & KCRM_MOUSE & P07310 & 10 \\
\hline 34 & $\begin{array}{c}\text { Creatine kinase, sarcomeric } \\
\text { mitochondrial precursor - Mus } \\
\text { musculus (Mouse) }\end{array}$ & 92 & 25 & 47899.49 & KCRS_MOUSE & \multirow{7}{*}{ Q6P8J7 } & \multirow{7}{*}{11} \\
\hline 35 & $\begin{array}{c}\text { Creatine kinase, sarcomeric } \\
\text { mitochondrial precursor - Mus } \\
\text { musculus (Mouse) }\end{array}$ & 101 & 28 & 47899.49 & KCRS_MOUSE & & \\
\hline 36 & $\begin{array}{l}\text { Creatine kinase, sarcomeric } \\
\text { mitochondrial precursor - Mus } \\
\text { musculus (Mouse) }\end{array}$ & 172 & 55 & 47899.49 & KCRS_MOUSE & & \\
\hline 37 & $\begin{array}{c}\text { Creatine kinase, sarcomeric } \\
\text { mitochondrial precursor - Mus } \\
\text { musculus (Mouse) }\end{array}$ & 211 & 64 & 47899.49 & KCRS_MOUSE & & \\
\hline 38 & $\begin{array}{l}\text { Creatine kinase, sarcomeric } \\
\text { mitochondrial precursor - Mus } \\
\text { musculus (Mouse) }\end{array}$ & 101 & 28 & 47899.49 & KCRS_MOUSE & & \\
\hline 39 & $\begin{array}{c}\text { Creatine kinase, sarcomeric } \\
\text { mitochondrial precursor - Mus } \\
\text { musculus (Mouse) }\end{array}$ & 129 & 43 & 47899.49 & KCRS_MOUSE & & \\
\hline 40 & $\begin{array}{c}\text { Creatine kinase, sarcomeric } \\
\text { mitochondrial precursor - Mus } \\
\text { musculus (Mouse) }\end{array}$ & 121 & 32 & 47899.49 & KCRS_MOUSE & & \\
\hline 41 & $\begin{array}{c}\text { Dehydrogenase/reductase - } \\
\text { Mus musculus (Mouse) }\end{array}$ & 38 & 18 & 35504.86 & Q148Q4_MOUSE & & \\
\hline 42 & $\begin{array}{c}\text { Glyceraldehyde-3-phosphate } \\
\text { dehydrogenase - Mus }\end{array}$ & 69 & 34 & 36072.32 & G3P_MOUSE & P16858 & 12 \\
\hline
\end{tabular}




\begin{tabular}{|c|c|c|c|c|c|c|c|}
\hline & musculus (Mouse) & & & & & & \\
\hline 43 & $\begin{array}{l}\text { Glyceraldehyde-3-phosphate } \\
\text { dehydrogenase - Mus } \\
\text { musculus (Mouse) }\end{array}$ & 138 & 55 & 36072.32 & G3P_MOUSE & & \\
\hline 44 & $\begin{array}{l}\text { Glyceraldehyde-3-phosphate } \\
\text { dehydrogenase - Mus } \\
\text { musculus (Mouse) }\end{array}$ & 128 & 54 & 36072.32 & G3P_MOUSE & & \\
\hline 45 & $\begin{array}{l}\text { Lethal(3)malignant brain } \\
\text { tumor-like protein - Mus } \\
\text { musculus (Mouse) }\end{array}$ & 28 & 56 & 5938.85 & Q3V555_MOUSE & & \\
\hline 46 & $\begin{array}{l}\text { Low-voltage-activated calcium } \\
\text { channel alpha13.2 subunit - } \\
\text { Mus musculus (Mouse) }\end{array}$ & 36 & 41 & 12283.98 & Q99P43_MOUSE & & \\
\hline 47 & $\begin{array}{l}\text { Myomesin-1 - Mus musculus } \\
\text { (Mouse) }\end{array}$ & 193 & 24 & 186470.45 & MYOM1_MOUSE & \multirow{8}{*}{ Q62234 } & \multirow{8}{*}{13} \\
\hline 48 & $\begin{array}{c}\text { Myomesin-1 - Mus musculus } \\
\text { (Mouse) }\end{array}$ & 315 & 34 & 186470.45 & MYOM1_MOUSE & & \\
\hline 49 & $\begin{array}{c}\text { Myomesin-1 - Mus musculus } \\
\text { (Mouse) }\end{array}$ & 306 & 35 & 186470.45 & MYOM1_MOUSE & & \\
\hline 50 & $\begin{array}{l}\text { Myomesin-1 - Mus musculus } \\
\text { (Mouse) }\end{array}$ & 251 & 33 & 186470.45 & MYOM1_MOUSE & & \\
\hline 51 & $\begin{array}{c}\text { Myomesin-1 - Mus musculus } \\
\text { (Mouse) }\end{array}$ & 326 & 36 & 186470.45 & MYOM1_MOUSE & & \\
\hline 52 & $\begin{array}{l}\text { Myomesin-1 - Mus musculus } \\
\text { (Mouse) }\end{array}$ & 245 & 28 & 186470.45 & MYOM1_MOUSE & & \\
\hline 53 & $\begin{array}{l}\text { Myomesin-1 - Mus musculus } \\
\text { (Mouse) }\end{array}$ & 219 & 30 & 186470.45 & MYOM1_MOUSE & & \\
\hline 54 & $\begin{array}{l}\text { Myomesin-1 - Mus musculus } \\
\text { (Mouse) }\end{array}$ & 91 & 14 & 186470.45 & MYOM1_MOUSE & & \\
\hline 55 & $\begin{array}{c}\text { Myosin heavy chain IIB - Mus } \\
\text { musculus (Mouse) }\end{array}$ & 84 & 18 & 61050.65 & Q9JHR4_MOUSE & Q9JHR4 & 14 \\
\hline 56 & $\begin{array}{l}\text { Myosin-binding protein C, fast- } \\
\text { type - Mus musculus (Mouse) }\end{array}$ & 217 & 33 & 128127.87 & MYPC2_MOUSE & \multirow{5}{*}{ Q5XKE0 } & \multirow{9}{*}{15} \\
\hline 57 & $\begin{array}{l}\text { Myosin-binding protein C, fast- } \\
\text { type - Mus musculus (Mouse) }\end{array}$ & 275 & 42 & 128127.87 & MYPC2_MOUSE & & \\
\hline 58 & $\begin{array}{l}\text { Myosin-binding protein C, fast- } \\
\text { type - Mus musculus (Mouse) }\end{array}$ & 150 & 31 & 128127.87 & MYPC2_MOUSE & & \\
\hline 59 & $\begin{array}{l}\text { Myosin-binding protein C, fast- } \\
\text { type - Mus musculus (Mouse) }\end{array}$ & 178 & 33 & 128127.87 & MYPC2_MOUSE & & \\
\hline 60 & $\begin{array}{l}\text { Myosin-binding protein C, fast- } \\
\text { type - Mus musculus (Mouse) }\end{array}$ & 293 & 39 & 128127.87 & MYPC2_MOUSE & & \\
\hline 61 & $\begin{array}{l}\text { Myosin-binding protein } \mathrm{H} \text { - } \\
\text { Mus musculus (Mouse) }\end{array}$ & 81 & 29 & 53068.82 & MYBPH_MOUSE & \multirow{4}{*}{ P70402 } & \\
\hline 62 & $\begin{array}{l}\text { Myosin-binding protein } \mathrm{H} \text { - } \\
\text { Mus musculus (Mouse) }\end{array}$ & 71 & 14 & 53068.82 & MYBPH_MOUSE & & \\
\hline 63 & $\begin{array}{l}\text { Myosin-binding protein } \mathrm{H} \text { - } \\
\text { Mus musculus (Mouse) }\end{array}$ & 68 & 14 & 53068.82 & MYBPH_MOUSE & & \\
\hline 64 & $\begin{array}{l}\text { Myosin-binding protein } \mathrm{H}- \\
\text { Mus musculus (Mouse) }\end{array}$ & 79 & 28 & 53068.82 & MYBPH_MOUSE & & \\
\hline 65 & $\begin{array}{l}\text { Otc protein - Mus musculus } \\
\text { (Mouse) }\end{array}$ & 30 & 12 & 39511.45 & Q8R1A8_MOUSE & & \\
\hline 66 & $\begin{array}{l}\text { RAS-like family } 11 \text { member A } \\
\text { - Mus musculus (Mouse) }\end{array}$ & 31 & 7 & 27221.18 & Q6IMB1_MOUSE & & \\
\hline 67 & $\begin{array}{c}\text { Stress-70 protein, } \\
\text { mitochondrial precursor - Mus }\end{array}$ & 71 & 18 & 73767.84 & GRP75_MOUSE & P38647 & 16 \\
\hline
\end{tabular}


Table 1.6: mass spec analysis of a 2D gel of a DTT-eluted fraction from lysate 2 (continued) derived from mouse skeletal muscles. The analysis is for the proteins remaining on the affinity column after acidic elution.

\begin{tabular}{|c|c|c|c|c|c|c|c|}
\hline $\begin{array}{c}\text { Spot } \\
\#\end{array}$ & Protein species & $\begin{array}{l}\text { Mascot } \\
\text { Score }\end{array}$ & $\begin{array}{c}\% \\
\text { Coverage }\end{array}$ & $\begin{array}{l}\text { Protein } \\
\text { MW }\end{array}$ & Accession & $\begin{array}{l}\text { Uniprot } \\
\text { ID }\end{array}$ & $\begin{array}{c}\# \\
\text { species }\end{array}$ \\
\hline 1 & $\begin{array}{c}0 \text { day neonate cerebellum } \\
\text { cDNA, RIKEN full-length } \\
\text { enriched library, } \\
\text { clone:C230089I12 } \\
\text { product:hypothe }\end{array}$ & 43 & 28 & 14380.01 & Q8C4A2_MOUSE & & \\
\hline 2 & $\begin{array}{l}10 \text { days neonate skin cDNA, } \\
\text { RIKEN full-length enriched } \\
\text { library, clone: } 4732482 K 20 \\
\text { product:TITIN, HEAR }\end{array}$ & 62 & 20 & 47977.68 & Q8C139_MOUSE & & \\
\hline 3 & $\begin{array}{c}13 \text { days embryo head cDNA, } \\
\text { RIKEN full-length enriched } \\
\text { library, clone:3110001F06 } \\
\text { product:cofilin 1, } \mathrm{n}\end{array}$ & 30 & 21 & 18775.76 & Q544Y7_MOUSE & & \\
\hline 4 & $\begin{array}{c}\text { 6430706D22Rik protein - Mus } \\
\text { musculus (Mouse) }\end{array}$ & 38 & 54 & 8161.08 & Q99KB1_MOUSE & & \\
\hline 5 & $\begin{array}{c}\text { Adenylate kinase isoenzyme } 1 \\
\text { - Mus musculus (Mouse) }\end{array}$ & 76 & 39 & 21640.16 & KAD1_MOUSE & \multirow{5}{*}{ Q9R0Y5 } & \multirow{5}{*}{1} \\
\hline 6 & $\begin{array}{c}\text { Adenylate kinase isoenzyme } 1 \\
\text { - Mus musculus (Mouse) }\end{array}$ & 87 & 60 & 21640.16 & KAD1_MOUSE & & \\
\hline 7 & $\begin{array}{c}\text { Adenylate kinase isoenzyme } 1 \\
\text { - Mus musculus (Mouse) }\end{array}$ & 83 & 55 & 21640.16 & KAD1_MOUSE & & \\
\hline 8 & $\begin{array}{l}\text { Adenylate kinase isoenzyme } 1 \\
\text { - Mus musculus (Mouse) }\end{array}$ & 63 & 24 & 21640.16 & KAD1_MOUSE & & \\
\hline 9 & $\begin{array}{l}\text { Adenylate kinase isoenzyme } 1 \\
\text { - Mus musculus (Mouse) }\end{array}$ & 65 & 30 & 21640.16 & KAD1_MOUSE & & \\
\hline 10 & Adult male diencephalon & 26 & 21 & 11469.66 & Q3TRY6_MOUSE & & \\
\hline
\end{tabular}




\begin{tabular}{|c|c|c|c|c|c|c|c|}
\hline & $\begin{array}{l}\text { cDNA, RIKEN full-length } \\
\text { enriched library, } \\
\text { clone:9330101M15 } \\
\text { product:hypothet }\end{array}$ & & & & & & \\
\hline 11 & $\begin{array}{l}\text { Adult male hypothalamus } \\
\text { cDNA, RIKEN full-length } \\
\text { enriched library, } \\
\text { clone:A230060C20 } \\
\text { product:ubiquiti }\end{array}$ & 30 & 7 & 22094.09 & Q8CAH4_MOUSE & & \\
\hline 12 & $\begin{array}{l}\text { Adult male urinary bladder } \\
\text { cDNA, RIKEN full-length } \\
\text { enriched library, } \\
\text { clone:9530003A05 } \\
\text { product:hypot }\end{array}$ & 36 & 7 & 133509.27 & Q8CBV3_MOUSE & & \\
\hline 13 & $\begin{array}{l}\text { Aldh1a3 protein - Mus } \\
\text { musculus (Mouse) }\end{array}$ & 31 & 28 & 18949.69 & Q810V9_MOUSE & & \\
\hline 14 & $\begin{array}{l}\text { Aldh1a3 protein - Mus } \\
\text { musculus (Mouse) }\end{array}$ & 28 & 28 & 18949.69 & Q810V9_MOUSE & & \\
\hline 15 & $\begin{array}{l}\text { Aldh1a3 protein - Mus } \\
\text { musculus (Mouse) }\end{array}$ & 30 & 28 & 18949.69 & Q810V9_MOUSE & & \\
\hline 16 & $\begin{array}{l}\text { Aldh1a3 protein - Mus } \\
\text { musculus (Mouse) }\end{array}$ & 30 & 28 & 18949.69 & Q810V9_MOUSE & & \\
\hline 17 & $\begin{array}{l}\text { Aldh1a3 protein - Mus } \\
\text { musculus (Mouse) }\end{array}$ & 45 & 30 & 18949.69 & Q810V9_MOUSE & & \\
\hline 18 & $\begin{array}{l}\text { Aldh1a3 protein - Mus } \\
\text { musculus (Mouse) }\end{array}$ & 40 & 30 & 18949.69 & Q810V9_MOUSE & & \\
\hline 19 & $\begin{array}{l}\text { Aldh1a3 protein - Mus } \\
\text { musculus (Mouse) }\end{array}$ & 31 & 28 & 18949.69 & Q810V9_MOUSE & & \\
\hline 20 & $\begin{array}{c}\text { Aldh1a3 protein - Mus } \\
\text { musculus (Mouse) }\end{array}$ & 29 & 28 & 18949.69 & Q810V9_MOUSE & & \\
\hline 21 & $\begin{array}{l}\text { Aldh1a3 protein - Mus } \\
\text { musculus (Mouse) }\end{array}$ & 30 & 28 & 18949.69 & Q810V9_MOUSE & & \\
\hline 22 & $\begin{array}{l}\text { Aldh3b2 protein - Mus } \\
\text { musculus (Mouse) }\end{array}$ & 29 & 23 & 20242.26 & Q497U8_MOUSE & & \\
\hline 23 & $\begin{array}{c}\text { Aldolase 1, } \mathrm{A} \text { isoform - Mus } \\
\text { musculus (Mouse) }\end{array}$ & 54 & 36 & 39787.45 & Q5FWB7_MOUSE & & \\
\hline 24 & $\begin{array}{l}\text { Blastocyst blastocyst cDNA, } \\
\text { RIKEN full-length enriched } \\
\text { library, clone:I1C0024B03 } \\
\text { product:UPF0183 pr }\end{array}$ & 27 & 17 & 26557.13 & Q3TKL5_MOUSE & & \\
\hline 25 & $\begin{array}{c}\text { Bone marrow macrophage } \\
\text { cDNA, RIKEN full-length } \\
\text { enriched library, } \\
\text { clone:I830044A19 } \\
\text { product:cellular }\end{array}$ & 37 & 22 & 19983.72 & Q3U935_MOUSE & & \\
\hline 26 & $\begin{array}{c}\text { Carbonic anhydrase } 3 \text { - Mus } \\
\text { musculus (Mouse) }\end{array}$ & 59 & 40 & 29632.75 & CAH3_MOUSE & \multirow{3}{*}{ P16015 } & \multirow{3}{*}{2} \\
\hline 27 & $\begin{array}{c}\text { Carbonic anhydrase } 3 \text { - Mus } \\
\text { musculus (Mouse) }\end{array}$ & 106 & 41 & 29632.75 & CAH3_MOUSE & & \\
\hline 28 & $\begin{array}{c}\text { Carbonic anhydrase } 3 \text { - Mus } \\
\text { musculus (Mouse) }\end{array}$ & 81 & 45 & 29632.75 & CAH3_MOUSE & & \\
\hline 29 & $\begin{array}{c}\text { Cellular nucleic acid-binding } \\
\text { protein - Mus musculus } \\
\text { (Mouse) }\end{array}$ & 76 & 40 & 20833.08 & CNBP_MOUSE & P53996 & 3 \\
\hline 30 & Cpsf4 protein - Mus musculus & 32 & 30 & 4626.31 & Q8R3L9_MOUSE & & \\
\hline
\end{tabular}




\begin{tabular}{|c|c|c|c|c|c|c|c|}
\hline & (Mouse) & & & & & & \\
\hline 31 & $\begin{array}{c}\text { Dual specificity protein } \\
\text { phosphatase } 3 \text { - Mus } \\
\text { musculus (Mouse) }\end{array}$ & 87 & 47 & 20687.29 & DUS3_MOUSE & Q9D7X3 & 4 \\
\hline 32 & $\begin{array}{l}\text { ES cells cDNA, RIKEN full- } \\
\text { length enriched library, } \\
\text { clone:2410014J02 } \\
\text { product:myosin light chain, } \\
\text { pho }\end{array}$ & 50 & 31 & 19057.39 & Q545G1_MOUSE & & \\
\hline 33 & $\begin{array}{l}\text { ES cells cDNA, RIKEN full- } \\
\text { length enriched library, } \\
\text { clone:2410014J02 } \\
\text { product:myosin light chain, } \\
\text { pho }\end{array}$ & 39 & 21 & 19057.39 & Q545G1_MOUSE & & \\
\hline 34 & $\begin{array}{l}\text { FERM domain containing 4A - } \\
\text { Mus musculus (Mouse) }\end{array}$ & 35 & 28 & 21080.99 & A3KGJ1_MOUSE & & \\
\hline 35 & $\begin{array}{l}\text { Galectin-1 - Mus musculus } \\
\text { (Mouse) }\end{array}$ & 80 & 52 & 15198.33 & LEG1_MOUSE & \multirow{2}{*}{ P16045 } & \multirow{2}{*}{5} \\
\hline 36 & $\begin{array}{c}\text { Galectin-1 - Mus musculus } \\
\text { (Mouse) }\end{array}$ & 72 & 45 & 15198.33 & LEG1_MOUSE & & \\
\hline 37 & $\begin{array}{l}\text { Glyceraldehyde-3-phosphate } \\
\text { dehydrogenase - Mus } \\
\text { musculus (Mouse) }\end{array}$ & 99 & 48 & 36072.32 & G3P_MOUSE & \multirow{11}{*}{ P16858 } & \multirow{11}{*}{6} \\
\hline 38 & $\begin{array}{c}\text { Glyceraldehyde-3-phosphate } \\
\text { dehydrogenase - Mus } \\
\text { musculus (Mouse) }\end{array}$ & 62 & 18 & 36072.32 & G3P_MOUSE & & \\
\hline 39 & $\begin{array}{l}\text { Glyceraldehyde-3-phosphate } \\
\text { dehydrogenase - Mus } \\
\text { musculus (Mouse) }\end{array}$ & 58 & 17 & 36072.32 & G3P_MOUSE & & \\
\hline 40 & $\begin{array}{c}\text { Glyceraldehyde-3-phosphate } \\
\text { dehydrogenase - Mus } \\
\text { musculus (Mouse) }\end{array}$ & 92 & 41 & 36072.32 & G3P_MOUSE & & \\
\hline 41 & $\begin{array}{c}\text { Glyceraldehyde-3-phosphate } \\
\text { dehydrogenase - Mus } \\
\text { musculus (Mouse) }\end{array}$ & 85 & 44 & 36072.32 & G3P_MOUSE & & \\
\hline 42 & $\begin{array}{c}\text { Glyceraldehyde-3-phosphate } \\
\text { dehydrogenase - Mus } \\
\text { musculus (Mouse) }\end{array}$ & 105 & 54 & 36072.32 & G3P_MOUSE & & \\
\hline 43 & $\begin{array}{c}\text { Glyceraldehyde-3-phosphate } \\
\text { dehydrogenase - Mus } \\
\text { musculus (Mouse) }\end{array}$ & 72 & 41 & 36072.32 & G3P_MOUSE & & \\
\hline 44 & $\begin{array}{c}\text { Glyceraldehyde-3-phosphate } \\
\text { dehydrogenase - Mus } \\
\text { musculus (Mouse) }\end{array}$ & 96 & 37 & 36072.32 & G3P_MOUSE & & \\
\hline 45 & $\begin{array}{c}\text { Glyceraldehyde-3-phosphate } \\
\text { dehydrogenase - Mus } \\
\text { musculus (Mouse) }\end{array}$ & 95 & 42 & 36072.32 & G3P_MOUSE & & \\
\hline 46 & $\begin{array}{c}\text { Glyceraldehyde-3-phosphate } \\
\text { dehydrogenase - Mus } \\
\text { musculus (Mouse) }\end{array}$ & 91 & 38 & 36072.32 & G3P_MOUSE & & \\
\hline 47 & $\begin{array}{c}\text { Glyceraldehyde-3-phosphate } \\
\text { dehydrogenase - Mus } \\
\text { musculus (Mouse) }\end{array}$ & 82 & 35 & 36072.32 & G3P_MOUSE & & \\
\hline 48 & $\begin{array}{c}\text { Glycerol-3-phosphate } \\
\text { dehydrogenase [NAD+], }\end{array}$ & 140 & 44 & 38175.66 & GPDA_MOUSE & P13707 & 7 \\
\hline
\end{tabular}




\begin{tabular}{|c|c|c|c|c|c|c|c|}
\hline & $\begin{array}{l}\text { cytoplasmic - Mus musculus } \\
\text { (Mouse) }\end{array}$ & & & & & & \\
\hline 49 & $\begin{array}{l}\text { Hemoglobin subunit beta-1 - } \\
\text { Mus musculus (Mouse) }\end{array}$ & 72 & 40 & 15944.19 & HBB1_MOUSE & P02088 & 8 \\
\hline 50 & $\begin{array}{c}\text { Keratin } 16 \text { - Mus musculus } \\
\text { (Mouse) }\end{array}$ & 48 & 18 & 51973.48 & Q3SYP5_MOUSE & & \\
\hline 51 & $\begin{array}{l}\text { Mercaptopyruvate } \\
\text { sulfurtransferase - Mus } \\
\text { musculus (Mouse) }\end{array}$ & 29 & 11 & 33246.61 & Q505N7_MOUSE & & \\
\hline 52 & $\begin{array}{l}\text { Myomesin-1 - Mus musculus } \\
\text { (Mouse) }\end{array}$ & 160 & 18 & 186470.45 & MYOM1_MOUSE & \multirow{2}{*}{ Q62234 } & \multirow{2}{*}{9} \\
\hline 53 & $\begin{array}{l}\text { Myomesin-1 - Mus musculus } \\
\text { (Mouse) }\end{array}$ & 159 & 22 & 186470.45 & MYOM1_MOUSE & & \\
\hline 54 & $\begin{array}{c}\text { Myosin light chain } 1, \text { skeletal } \\
\text { muscle isoform - Mus } \\
\text { musculus (Mouse) }\end{array}$ & 119 & 75 & 20695.45 & MLE1_MOUSE & P05977 & 10 \\
\hline 55 & $\begin{array}{l}\text { Myosin regulatory light chain } \\
2 \text {, skeletal muscle isoform - } \\
\text { Mus musculus (Mouse) }\end{array}$ & 115 & 55 & 19057.39 & MLRS_MOUSE & \multirow[b]{2}{*}{ P97457 } & \multirow{2}{*}{11} \\
\hline 56 & $\begin{array}{l}\text { Myosin regulatory light chain } \\
\text { 2, skeletal muscle isoform - } \\
\text { Mus musculus (Mouse) }\end{array}$ & 58 & 40 & 19057.39 & MLRS_MOUSE & & \\
\hline 57 & $\begin{array}{l}\text { Myosin, heavy polypeptide 1, } \\
\text { skeletal muscle, adult - Mus } \\
\text { musculus (Mouse) }\end{array}$ & 31 & 5 & 224115.73 & Q32P18_MOUSE & & \\
\hline 58 & $\begin{array}{l}\text { Myosin-binding protein C, fast- } \\
\text { type - Mus musculus (Mouse) }\end{array}$ & 97 & 28 & 128127.87 & MYPC2_MOUSE & Q5XKE0 & 12 \\
\hline 59 & $\begin{array}{l}\text { Peroxiredoxin-1 - Mus } \\
\text { musculus (Mouse) }\end{array}$ & 86 & 41 & 22390.44 & PRDX1_MOUSE & \multirow{2}{*}{ P35700 } & \multirow{2}{*}{13} \\
\hline 60 & $\begin{array}{l}\text { Peroxiredoxin-1 - Mus } \\
\text { musculus (Mouse) }\end{array}$ & 158 & 63 & 22390.44 & PRDX1_MOUSE & & \\
\hline 61 & $\begin{array}{c}\text { Polymerase kappa isoform } 1 \text { - } \\
\text { Mus musculus (Mouse) }\end{array}$ & 34 & 22 & 60850.15 & Q5Q9H8_MOUSE & & \\
\hline 62 & $\begin{array}{l}\text { Protein DJ-1 - Mus musculus } \\
\text { (Mouse) }\end{array}$ & 96 & 56 & 20236.47 & PARK7_MOUSE & Q99LX0 & 14 \\
\hline 63 & $\begin{array}{c}\text { Protein LRP16 - Mus } \\
\text { musculus (Mouse) }\end{array}$ & 72 & 26 & 35842.59 & LRP16_MOUSE & Q922B1 & 15 \\
\hline 64 & $\begin{array}{l}\text { Triosephosphate isomerase - } \\
\text { Mus musculus (Mouse) }\end{array}$ & 128 & 53 & 27037.89 & TPIS_MOUSE & \multirow{4}{*}{ P17751 } & \multirow{4}{*}{16} \\
\hline 65 & $\begin{array}{c}\text { Triosephosphate isomerase - } \\
\text { Mus musculus (Mouse) }\end{array}$ & 108 & 53 & 27037.89 & TPIS_MOUSE & & \\
\hline 66 & $\begin{array}{c}\text { Triosephosphate isomerase - } \\
\text { Mus musculus (Mouse) }\end{array}$ & 118 & 61 & 27037.89 & TPIS_MOUSE & & \\
\hline 67 & $\begin{array}{c}\text { Triosephosphate isomerase - } \\
\text { Mus musculus (Mouse) }\end{array}$ & 104 & 46 & 27037.89 & TPIS_MOUSE & & \\
\hline 68 & $\begin{array}{c}\text { Troponin C, skeletal muscle - } \\
\text { Mus musculus (Mouse) }\end{array}$ & 109 & 50 & 18155.38 & TNNC2_MOUSE & \multirow{2}{*}{ P20801 } & \multirow{2}{*}{17} \\
\hline 69 & $\begin{array}{c}\text { Troponin C, skeletal muscle - } \\
\text { Mus musculus (Mouse) }\end{array}$ & 81 & 40 & 18155.38 & TNNC2_MOUSE & & \\
\hline 70 & $\begin{array}{c}\text { Ttn protein - Mus musculus } \\
\text { (Mouse) }\end{array}$ & 78 & 24 & 39353.95 & Q8R112_MOUSE & Q8R112 & 18 \\
\hline 71 & $\begin{array}{l}\text { Zinc finger protein } 248 \text { - Mus } \\
\text { musculus (Mouse) }\end{array}$ & 38 & 17 & 68338.20 & Q640N4_MOUSE & & \\
\hline
\end{tabular}


Table 1.7: mass spec analysis of a 2D gel of an acid-eluted fraction from a lysate derived from mouse kidneys.

\begin{tabular}{|c|c|c|c|c|c|c|c|}
\hline $\begin{array}{c}\text { Spot } \\
\#\end{array}$ & Protein species & Score & $\begin{array}{c}\% \\
\text { Coverage }\end{array}$ & $\begin{array}{c}\text { Protein } \\
\text { MW }\end{array}$ & Accession & $\begin{array}{c}\text { Uniprot } \\
\text { ID }\end{array}$ & $\begin{array}{c}\text { \# of } \\
\text { species }\end{array}$ \\
\hline 1 & $\begin{array}{c}\text { 14-3-3 protein epsilon - Mus } \\
\text { musculus (Mouse) }\end{array}$ & 77 & 34 & 29326.48 & 1433E_MOUSE & P62259 & 1 \\
\hline 2 & $\begin{array}{c}\text { 2210023G05Rik protein - } \\
\text { Mus musculus (Mouse) }\end{array}$ & 28 & 73 & 3312.91 & Q8K197_MOUSE & & \\
\hline 3 & $\begin{array}{l}\text { 40S ribosomal protein S18 - } \\
\text { Mus musculus (Mouse) }\end{array}$ & 63 & 40 & 17707.86 & RS18_MOUSE & P62270 & 2 \\
\hline 4 & $\begin{array}{l}6 \text { days neonate head cDNA, } \\
\text { RIKEN full-length enriched } \\
\text { library, clone:5430417M15 } \\
\text { product:hypothetical }\end{array}$ & 48 & 14 & 85514.92 & Q8C0L4_MOUSE & & \\
\hline 5 & $\begin{array}{l}\text { Activated spleen cDNA, } \\
\text { RIKEN full-length enriched } \\
\text { library, clone:F830207J03 } \\
\text { product:yes-associated }\end{array}$ & 35 & 24 & 25090.58 & Q3U046_MOUSE & & \\
\hline 6 & $\begin{array}{c}\text { Aldehyde dehydrogenase, } \\
\text { mitochondrial precursor - Mus } \\
\text { musculus (Mouse) }\end{array}$ & 145 & 39 & 57014.94 & ALDH2_MOUSE & \multirow{2}{*}{ P47738 } & 3 \\
\hline 7 & $\begin{array}{c}\text { Aldehyde dehydrogenase, } \\
\text { mitochondrial precursor - Mus } \\
\text { musculus (Mouse) }\end{array}$ & 87 & 20 & 57014.94 & ALDH2_MOUSE & & \\
\hline 8 & $\begin{array}{l}\text { Aldh1a3 protein - Mus } \\
\text { musculus (Mouse) }\end{array}$ & 33 & 32 & 18949.69 & Q810V9_MOUSE & & \\
\hline 9 & $\begin{array}{l}\text { Aldh1a3 protein - Mus } \\
\text { musculus (Mouse) }\end{array}$ & 34 & 32 & 18949.69 & Q810V9_MOUSE & & \\
\hline 10 & $\begin{array}{l}\text { Alpha-actinin-4 - Mus } \\
\text { musculus (Mouse) }\end{array}$ & 65 & 12 & 105367.59 & ACTN4_MOUSE & P57780 & 4 \\
\hline 11 & $\begin{array}{c}\text { Argininosuccinate synthase - } \\
\text { Mus musculus (Mouse) }\end{array}$ & 91 & 34 & 46840.12 & ASSY_MOUSE & \multirow{2}{*}{ P16460 } & \multirow{2}{*}{5} \\
\hline 12 & $\begin{array}{l}\text { Argininosuccinate synthase - } \\
\text { Mus musculus (Mouse) }\end{array}$ & 69 & 15 & 46840.12 & ASSY_MOUSE & & \\
\hline 13 & $\begin{array}{c}\text { ARL-6 interacting protein-2 - } \\
\text { Mus musculus (Mouse) }\end{array}$ & 28 & 9 & 16442.39 & Q9WUG4_MOUSE & & \\
\hline 14 & $\begin{array}{l}\text { Aspartoacylase-2 - Mus } \\
\text { musculus (Mouse) }\end{array}$ & 74 & 38 & 35719.76 & ACY3_MOUSE & Q91XE4 & 6 \\
\hline 15 & $\begin{array}{l}\text { ATP synthase subunit beta, } \\
\text { mitochondrial precursor - Mus } \\
\text { musculus (Mouse) }\end{array}$ & 77 & 25 & 56265.46 & ATPB_MOUSE & \multirow{2}{*}{ P56480 } & \multirow{2}{*}{7} \\
\hline 16 & $\begin{array}{l}\text { ATP synthase subunit beta, } \\
\text { mitochondrial precursor - Mus } \\
\text { musculus (Mouse) }\end{array}$ & 166 & 45 & 56265.46 & ATPB_MOUSE & & \\
\hline 17 & $\begin{array}{c}\text { ATP synthase, } \mathrm{H+} \\
\text { transporting, mitochondrial F0 } \\
\text { complex, subunit } d \text { - Mus } \\
\text { musculus (Mouse) }\end{array}$ & 56 & 41 & 18794.61 & A2A8X4_MOUSE & & \\
\hline 18 & $\begin{array}{c}\text { Cytidine deaminase - Mus } \\
\text { musculus (Mouse) }\end{array}$ & 85 & 73 & 16520.10 & CDD_MOUSE & P56389 & 8 \\
\hline 19 & $\begin{array}{l}\text { Dihydropyrimidinase-related } \\
\text { protein } 2 \text { - Mus musculus }\end{array}$ & 130 & 31 & 62637.74 & DPYL2_MOUSE & O08553 & 9 \\
\hline
\end{tabular}




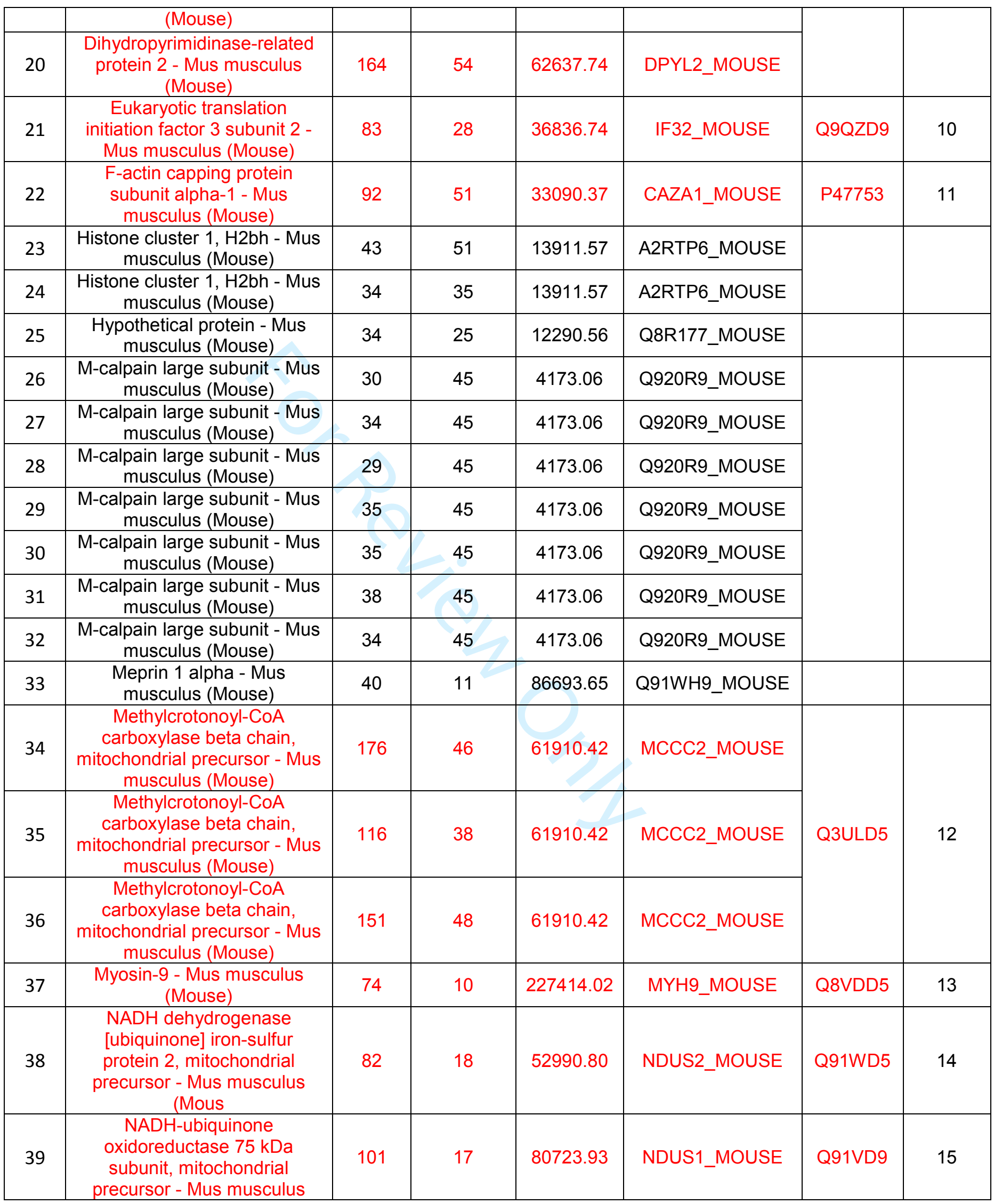




\begin{tabular}{|c|c|c|c|c|c|c|c|}
\hline & (Mouse) & & & & & & \\
\hline 40 & $\begin{array}{l}\text { Oxysterol binding protein } 2 \text { - } \\
\text { Mus musculus (Mouse) }\end{array}$ & 41 & 92 & 3507.68 & Q5F210_MOUSE & & \\
\hline 41 & $\begin{array}{l}\text { Peroxiredoxin-2 - Mus } \\
\text { musculus (Mouse) }\end{array}$ & 67 & 31 & 21936.12 & PRDX2_MOUSE & Q61171 & 16 \\
\hline 42 & $\begin{array}{c}\text { Peroxiredoxin-5, } \\
\text { mitochondrial precursor - Mus } \\
\text { musculus (Mouse) }\end{array}$ & 62 & 42 & 22225.67 & PRDX5_MOUSE & \multirow{8}{*}{ P99029 } & \multirow{8}{*}{17} \\
\hline 43 & $\begin{array}{c}\text { Peroxiredoxin-5, } \\
\text { mitochondrial precursor - Mus } \\
\text { musculus (Mouse) }\end{array}$ & 108 & 50 & 22225.67 & PRDX5_MOUSE & & \\
\hline 44 & $\begin{array}{c}\text { Peroxiredoxin-5, } \\
\text { mitochondrial precursor - Mus } \\
\text { musculus (Mouse) }\end{array}$ & 115 & 55 & 22225.67 & PRDX5_MOUSE & & \\
\hline 45 & $\begin{array}{c}\text { Peroxiredoxin-5, } \\
\text { mitochondrial precursor - Mus } \\
\text { musculus (Mouse) }\end{array}$ & 108 & 45 & 22225.67 & PRDX5_MOUSE & & \\
\hline 46 & $\begin{array}{c}\text { Peroxiredoxin-5, } \\
\text { mitochondrial precursor - Mus } \\
\text { musculus (Mouse) }\end{array}$ & 164 & 45 & 22225.67 & PRDX5_MOUSE & & \\
\hline 47 & $\begin{array}{c}\text { Peroxiredoxin-5, } \\
\text { mitochondrial precursor - Mus } \\
\text { musculus (Mouse) }\end{array}$ & 160 & 56 & 22225.67 & PRDX5_MOUSE & & \\
\hline 48 & $\begin{array}{c}\text { Peroxiredoxin-5, } \\
\text { mitochondrial precursor - Mus } \\
\text { musculus (Mouse) }\end{array}$ & 157 & 67 & 22225.67 & PRDX5_MOUSE & & \\
\hline 49 & $\begin{array}{c}\text { Peroxiredoxin-5, } \\
\text { mitochondrial precursor - Mus } \\
\text { musculus (Mouse) }\end{array}$ & 146 & 55 & 22225.67 & PRDX5_MOUSE & & \\
\hline 50 & $\begin{array}{c}\text { Ppnx protein - Mus musculus } \\
\text { (Mouse) }\end{array}$ & 28 & 11 & 33504.96 & Q8K3S0_MOUSE & & \\
\hline 51 & $\begin{array}{l}\text { RAS-like family } 11 \text { member A } \\
\text { - Mus musculus (Mouse) }\end{array}$ & 34 & 7 & 27221.18 & Q6IMB1_MOUSE & & \\
\hline 52 & $\begin{array}{l}\text { RAS-like family } 11 \text { member A } \\
\text { - Mus musculus (Mouse) }\end{array}$ & 31 & 7 & 27221.18 & Q6IMB1_MOUSE & & \\
\hline 53 & $\begin{array}{l}\text { RAS-like family } 11 \text { member A } \\
\text { - Mus musculus (Mouse) }\end{array}$ & 29 & 7 & 27221.18 & Q6IMB1_MOUSE & & \\
\hline 54 & $\begin{array}{l}\text { RAS-like family } 11 \text { member A } \\
\text { - Mus musculus (Mouse) }\end{array}$ & 27 & 7 & 27221.18 & Q6IMB1_MOUSE & & \\
\hline 55 & $\begin{array}{l}\text { RAS-like family } 11 \text { member A } \\
\text { - Mus musculus (Mouse) }\end{array}$ & 34 & 7 & 27221.18 & Q6IMB1_MOUSE & & \\
\hline 56 & $\begin{array}{l}\text { RAS-like family } 11 \text { member A } \\
\text { - Mus musculus (Mouse) }\end{array}$ & 31 & 7 & 27221.18 & Q6IMB1_MOUSE & & \\
\hline 57 & $\begin{array}{l}\text { Septin-2 - Mus musculus } \\
\text { (Mouse) }\end{array}$ & 58 & 26 & 41727.36 & SEPT2_MOUSE & P42208 & 18 \\
\hline 58 & $\begin{array}{l}\text { Spectrin alpha chain, brain - } \\
\text { Mus musculus (Mouse) }\end{array}$ & 248 & 16 & 285220.58 & SPTA2_MOUSE & P16546 & 19 \\
\hline 59 & $\begin{array}{l}\text { Succinate dehydrogenase } \\
\text { [ubiquinone] flavoprotein } \\
\text { subunit, mitochondrial } \\
\text { precursor - Mus musculus ( }\end{array}$ & 243 & 58 & 73622.58 & DHSA_MOUSE & & \\
\hline 60 & $\begin{array}{l}\text { Succinate dehydrogenase } \\
\text { [ubiquinone] flavoprotein } \\
\text { subunit, mitochondrial } \\
\text { precursor - Mus musculus ( }\end{array}$ & 225 & 52 & 73622.58 & DHSA_MOUSE & Q8K2B3 & 20 \\
\hline
\end{tabular}


Table 1.8: mass spec analysis of a 2D gel of a DTT-eluted fraction from a lysate derived from mouse kidneys. The analysis is for the proteins remaining on the affinity column after acidic elution.

\begin{tabular}{|c|c|c|c|c|c|c|c|}
\hline $\begin{array}{c}\text { Spot } \\
\#\end{array}$ & Protein species & Score & $\begin{array}{c}\% \\
\text { Coverage }\end{array}$ & $\begin{array}{c}\text { Protein } \\
\text { MW }\end{array}$ & Accession & $\begin{array}{l}\text { Uniprot } \\
\text { ID }\end{array}$ & $\begin{array}{c}\text { \# of } \\
\text { species }\end{array}$ \\
\hline 1 & $\begin{array}{l}0 \text { day neonate cerebellum cDNA, } \\
\text { RIKEN full-length enriched } \\
\text { library, clone:C230058P07 } \\
\text { product:cell di }\end{array}$ & 31 & 27 & 12748.55 & Q3TQ50_MOUSE & & \\
\hline 2 & $\begin{array}{c}10 \text { days neonate cortex cDNA, } \\
\text { RIKEN full-length enriched } \\
\text { library, clone:A830014I19 } \\
\text { product:weakly si }\end{array}$ & 35 & 11 & 88533.14 & Q8BLR8_MOUSE & & \\
\hline 3 & $\begin{array}{c}\text { 10-formyltetrahydrofolate } \\
\text { dehydrogenase - Mus musculus } \\
\text { (Mouse) }\end{array}$ & 72 & 9 & 99501.84 & FTHFD_MOUSE & Q8R0Y6 & 1 \\
\hline 4 & $\begin{array}{c}11 \text { days embryo whole body } \\
\text { cDNA, RIKEN full-length } \\
\text { enriched library, } \\
\text { clone: } 2700084 \mathrm{~K} 13 \\
\text { product:annexi }\end{array}$ & 49 & 25 & 38926.90 & Q9CZI7_MOUSE & & \\
\hline 5 & $\begin{array}{l}13 \text { days embryo heart cDNA, } \\
\text { RIKEN full-length enriched } \\
\text { library, clone:D330037K14 } \\
\text { product:cadherin } 16\end{array}$ & 38 & 9 & 86851.68 & Q3TPA4_MOUSE & & \\
\hline 6 & $\begin{array}{c}13 \text { days embryo male testis } \\
\text { cDNA, RIKEN full-length } \\
\text { enriched library, } \\
\text { clone:6030400N17 } \\
\text { product:CGMP- }\end{array}$ & 37 & 14 & 32360.93 & Q8BJ62_MOUSE & & \\
\hline 7 & $\begin{array}{c}\text { 2810051F02Rik protein - Mus } \\
\text { musculus (Mouse) }\end{array}$ & 39 & 33 & 12483.39 & Q91VT2_MOUSE & & \\
\hline 8 & $\begin{array}{c}\text { 3-hydroxyanthranilate 3,4- } \\
\text { dioxygenase - Mus musculus } \\
\text { (Mouse) }\end{array}$ & 158 & 57 & 32954.63 & 3HAO_MOUSE & \multirow{3}{*}{ Q78JT3 } & \multirow{3}{*}{2} \\
\hline 9 & $\begin{array}{c}\text { 3-hydroxyanthranilate 3,4- } \\
\text { dioxygenase - Mus musculus } \\
\text { (Mouse) }\end{array}$ & 166 & 54 & 32954.63 & 3HAO_MOUSE & & \\
\hline 10 & $\begin{array}{c}\text { 3-hydroxyanthranilate 3,4- } \\
\text { dioxygenase - Mus musculus } \\
\text { (Mouse) }\end{array}$ & 130 & 50 & 32954.63 & 3HAO_MOUSE & & \\
\hline
\end{tabular}




\begin{tabular}{|c|c|c|c|c|c|c|c|}
\hline 11 & $\begin{array}{c}\text { 40S ribosomal protein S12 - Mus } \\
\text { musculus (Mouse) }\end{array}$ & 66 & 34 & 14857.68 & RS12_MOUSE & P63323 & 3 \\
\hline 12 & $\begin{array}{c}60 \text { kDa heat shock protein, } \\
\text { mitochondrial precursor - Mus } \\
\text { musculus (Mouse) }\end{array}$ & 100 & 42 & 61088.45 & CH60_MOUSE & P63038 & 4 \\
\hline 13 & $\begin{array}{c}\text { Abca7 protein - Mus musculus } \\
\text { (Mouse) }\end{array}$ & 28 & 14 & 34187.76 & Q8R1I3_MOUSE & & \\
\hline 14 & $\begin{array}{l}\text { Acetyl-coenzyme A synthetase } \\
\text { 2-like, mitochondrial precursor - } \\
\text { Mus musculus (Mouse) }\end{array}$ & 89 & 13 & 75317.07 & ACS2L_MOUSE & Q99NB1 & 5 \\
\hline 15 & $\begin{array}{l}\text { Acid phosphatase 1, soluble - } \\
\text { Mus musculus (Mouse) }\end{array}$ & 35 & 24 & 18636.05 & Q4VAI2_MOUSE & & \\
\hline 16 & $\begin{array}{c}\text { Aconitate hydratase, } \\
\text { mitochondrial precursor - Mus } \\
\text { musculus (Mouse) }\end{array}$ & 121 & 18 & 86151.30 & ACON_MOUSE & Q99KI0 & 6 \\
\hline 17 & $\begin{array}{l}\text { Activated spleen cDNA, RIKEN } \\
\text { full-length enriched library, } \\
\text { clone:F830207J03 product:yes- } \\
\text { associated }\end{array}$ & 36 & 20 & 25090.58 & Q3U046_MOUSE & & \\
\hline 18 & $\begin{array}{c}\text { Adenylate kinase isoenzyme } 1 \text { - } \\
\text { Mus musculus (Mouse) }\end{array}$ & 69 & 39 & 21640.16 & KAD1_MOUSE & Q9R0Y5 & 7 \\
\hline 19 & $\begin{array}{c}\text { Adult male cerebellum cDNA, } \\
\text { RIKEN full-length enriched } \\
\text { library, clone:1500019E20 } \\
\text { product:hypothetic }\end{array}$ & 107 & 63 & 28412.37 & Q9DB29_MOUSE & Q9DB29 & 8 \\
\hline 20 & $\begin{array}{c}\text { Adult male corpora quadrigemina } \\
\text { cDNA, RIKEN full-length } \\
\text { enriched library, } \\
\text { clone:B230213G02 product: }\end{array}$ & 32 & 12 & 24908.50 & Q8BR60_MOUSE & & \\
\hline 21 & $\begin{array}{c}\text { Adult male corpora quadrigemina } \\
\text { cDNA, RIKEN full-length } \\
\text { enriched library, } \\
\text { clone:B230314C10 product: }\end{array}$ & 33 & 30 & 14356.03 & Q3USS7_MOUSE & & \\
\hline 22 & $\begin{array}{l}\text { Adult male corpora quadrigemina } \\
\text { cDNA, RIKEN full-length } \\
\text { enriched library, } \\
\text { clone:B230314C10 product: }\end{array}$ & 40 & 39 & 14356.03 & Q3USS7_MOUSE & & \\
\hline 23 & $\begin{array}{c}\text { Adult male kidney cDNA, RIKEN } \\
\text { full-length enriched library, } \\
\text { clone:F530014F22 } \\
\text { product:hypothetical G }\end{array}$ & 29 & 27 & 15835.84 & Q3UNU4_MOUSE & & \\
\hline 24 & $\begin{array}{l}\text { Adult male liver tumor cDNA, } \\
\text { RIKEN full-length enriched } \\
\text { library, clone:C730013P19 } \\
\text { product:heat shoc }\end{array}$ & 45 & 12 & 56971.78 & Q3UEM8_MOUSE & & \\
\hline 25 & $\begin{array}{c}\text { Adult male testis cDNA, RIKEN } \\
\text { full-length enriched library, } \\
\text { clone:4922503G09 } \\
\text { product:down-regulated }\end{array}$ & 35 & 22 & 42230.41 & Q3TTP7_MOUSE & & \\
\hline 26 & $\begin{array}{l}\text { Aldh1a3 protein - Mus musculus } \\
\text { (Mouse) }\end{array}$ & 34 & 28 & 18949.69 & Q810V9_MOUSE & & \\
\hline 27 & $\begin{array}{l}\text { Aldh1a3 protein - Mus musculus } \\
\text { (Mouse) }\end{array}$ & 31 & 28 & 18949.69 & Q810V9_MOUSE & & \\
\hline 28 & $\begin{array}{l}\text { Aldh1a3 protein - Mus musculus } \\
\text { (Mouse) }\end{array}$ & 30 & 28 & 18949.69 & Q810V9_MOUSE & & \\
\hline
\end{tabular}




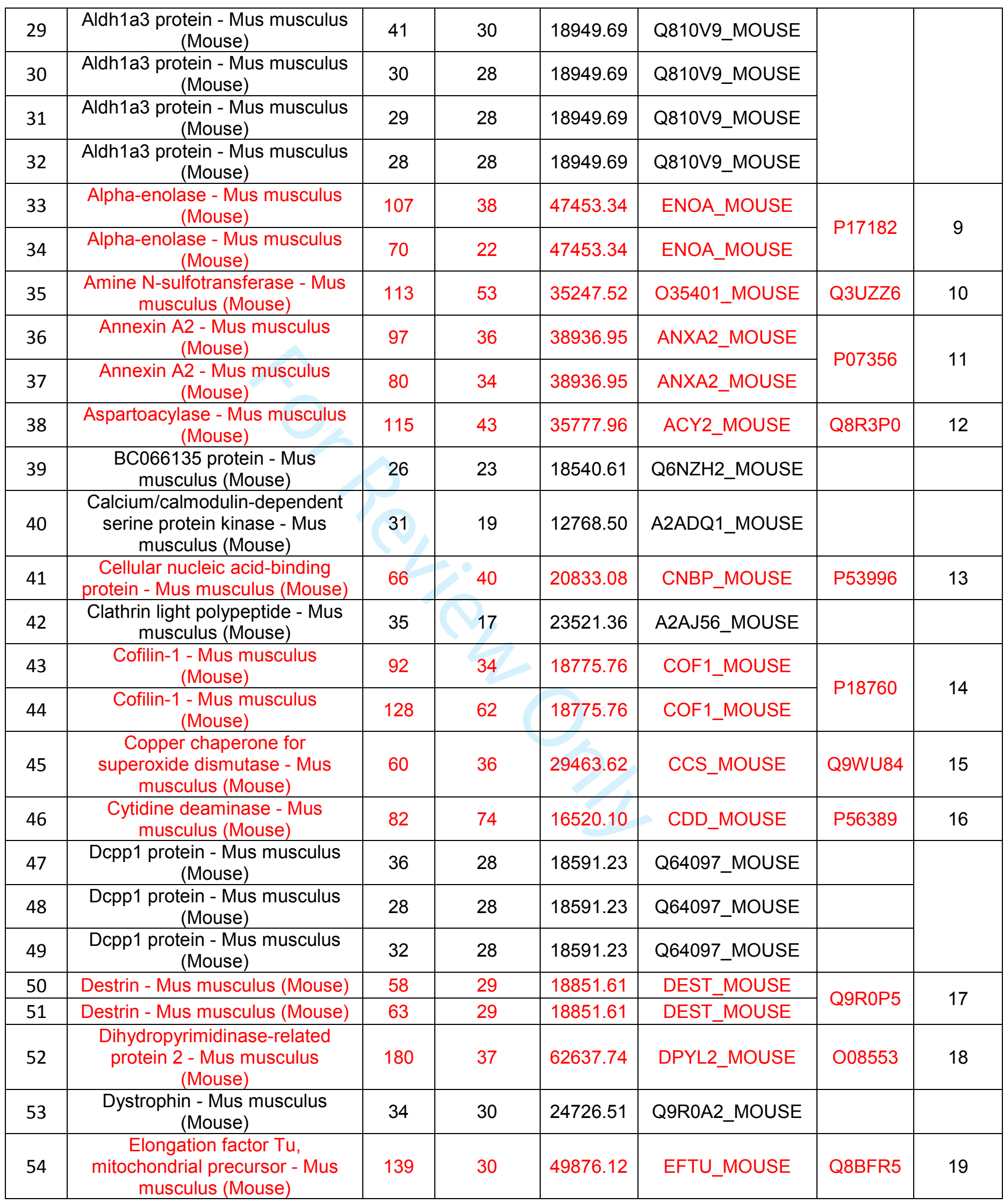




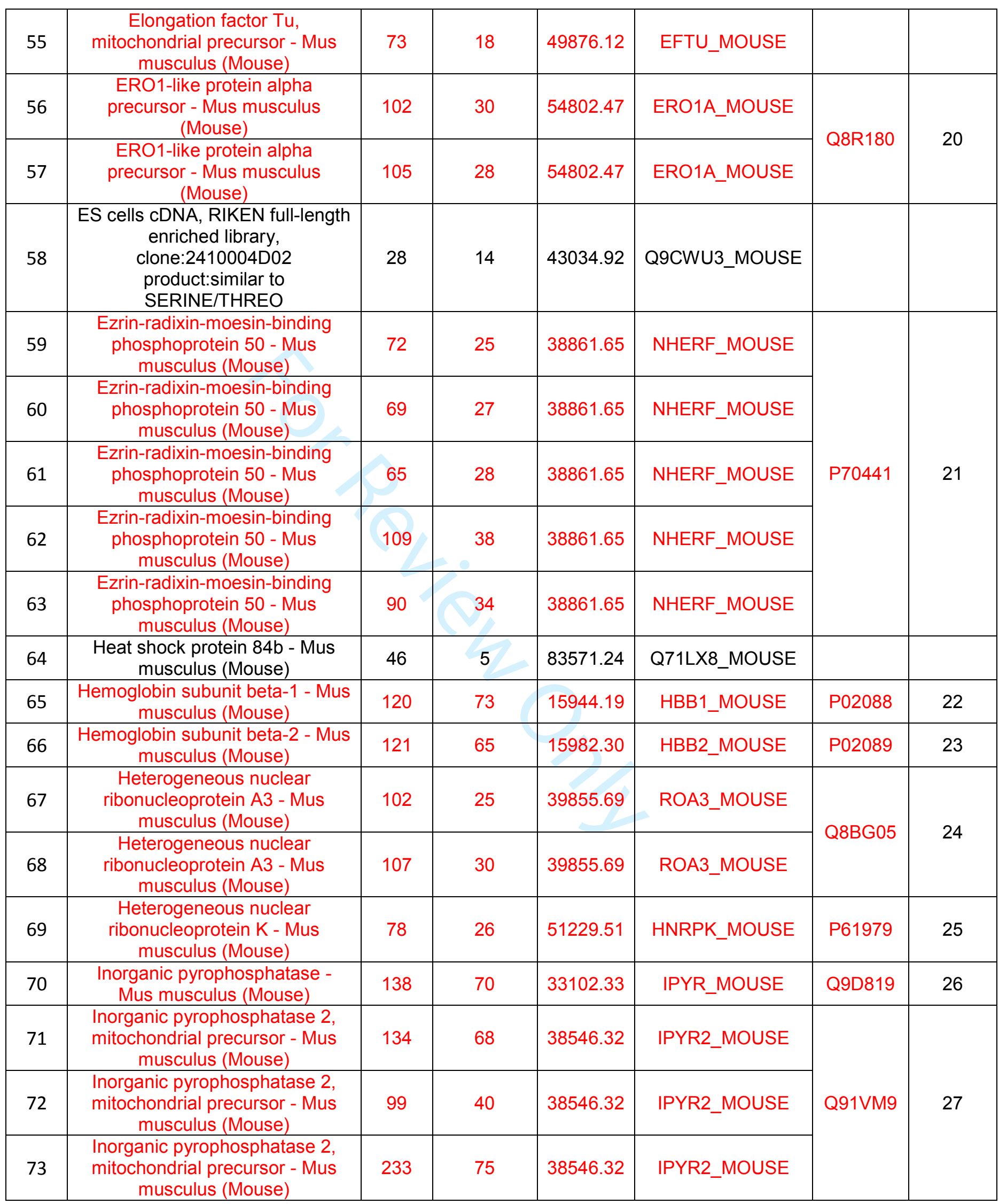




\begin{tabular}{|c|c|c|c|c|c|c|c|}
\hline 74 & $\begin{array}{l}\text { Interleukin } 15 \text { receptor alpha } \\
\text { chain isoform } 2 D \text { - Mus } \\
\text { musculus (Mouse) }\end{array}$ & 42 & 42 & 11211.70 & Q810T6_MOUSE & & \\
\hline 75 & $\begin{array}{c}\text { Leukocyte elastase inhibitor A - } \\
\text { Mus musculus (Mouse) }\end{array}$ & 95 & 27 & 42718.83 & ILEUA_MOUSE & \multirow{2}{*}{ Q9D154 } & \multirow{2}{*}{28} \\
\hline 76 & $\begin{array}{c}\text { Leukocyte elastase inhibitor A - } \\
\text { Mus musculus (Mouse) }\end{array}$ & 147 & 32 & 42718.83 & ILEUA_MOUSE & & \\
\hline 77 & $\begin{array}{c}\text { Low-voltage-activated calcium } \\
\text { channel alpha13.2 subunit - Mus } \\
\text { musculus (Mouse) }\end{array}$ & 42 & 41 & 12283.98 & Q99P43_MOUSE & & \\
\hline 78 & $\begin{array}{l}\text { Lung RCB-0558 LLC cDNA, } \\
\text { RIKEN full-length enriched } \\
\text { library, clone:G730038B15 } \\
\text { product:similar to Msz }\end{array}$ & 41 & 16 & 68198.96 & Q3UML8_MOUSE & & \\
\hline 79 & $\begin{array}{c}\text { Meprin } 1 \text { alpha - Mus musculus } \\
\text { (Mouse) }\end{array}$ & 50 & 15 & 86693.65 & Q91WH9_MOUSE & & \\
\hline 80 & $\begin{array}{l}\text { Meprin A subunit alpha precursor } \\
\text { - Mus musculus (Mouse) }\end{array}$ & 69 & 12 & 85226.89 & MEP1A_MOUSE & P28825 & 29 \\
\hline 81 & $\begin{array}{l}\text { Mitochondrial inner membrane } \\
\text { protein - Mus musculus (Mouse) }\end{array}$ & 80 & 13 & 84247.35 & IMMT_MOUSE & \multirow{2}{*}{ Q8CAQ8 } & \multirow{2}{*}{30} \\
\hline 82 & $\begin{array}{l}\text { Mitochondrial inner membrane } \\
\text { protein - Mus musculus (Mouse) }\end{array}$ & 157 & 29 & 84247.35 & IMMT_MOUSE & & \\
\hline 83 & NIMA - Mus musculus (Mouse) & 32 & 100 & 4423.07 & A2ATP0_MOUSE & & \\
\hline 84 & $\begin{array}{c}\text { NOD-derived CD11c +ve } \\
\text { dendritic cells cDNA, RIKEN full- } \\
\text { length enriched library, } \\
\text { clone:F630006F12 pr }\end{array}$ & 36 & 22 & 33614.01 & Q3TDV6_MOUSE & & \\
\hline 85 & $\begin{array}{c}\text { Nucleoside diphosphate-linked } \\
\text { moiety X motif } 19 \text { - Mus } \\
\text { musculus (Mouse) }\end{array}$ & 64 & 16 & 40798.59 & NUD19_MOUSE & \multirow{5}{*}{ P11930 } & \multirow{5}{*}{31} \\
\hline 86 & $\begin{array}{c}\text { Nucleoside diphosphate-linked } \\
\text { moiety X motif } 19 \text { - Mus } \\
\text { musculus (Mouse) }\end{array}$ & 94 & 50 & 40798.59 & NUD19_MOUSE & & \\
\hline 87 & $\begin{array}{l}\text { Nucleoside diphosphate-linked } \\
\text { moiety X motif } 19 \text { - Mus } \\
\text { musculus (Mouse) }\end{array}$ & 113 & 47 & 40798.59 & NUD19_MOUSE & & \\
\hline 88 & $\begin{array}{c}\text { Nucleoside diphosphate-linked } \\
\text { moiety X motif } 19 \text { - Mus } \\
\text { musculus (Mouse) }\end{array}$ & 121 & 50 & 40798.59 & NUD19_MOUSE & & \\
\hline 89 & $\begin{array}{c}\text { Nucleoside diphosphate-linked } \\
\text { moiety X motif } 19 \text { - Mus } \\
\text { musculus (Mouse) }\end{array}$ & 72 & 22 & 40798.59 & NUD19_MOUSE & & \\
\hline 90 & $\begin{array}{c}\text { Osteoclast-like cell cDNA, } \\
\text { RIKEN full-length enriched } \\
\text { library, clone:I420027B09 } \\
\text { product:fibulin 1, }\end{array}$ & 36 & 13 & 82114.18 & Q3TWK8_MOUSE & & \\
\hline 91 & $\begin{array}{l}\text { Osteoclast-like cell cDNA, } \\
\text { RIKEN full-length enriched } \\
\text { library, clone:I420031B14 } \\
\text { product:Weakly simi }\end{array}$ & 212 & 32 & 57318.99 & Q3TW96_MOUSE & Q3TW96 & 32 \\
\hline 92 & $\begin{array}{c}\text { Patched homolog } 1 \text { splice variant } \\
\text { 1B - Mus musculus (Mouse) }\end{array}$ & 20 & 62 & 2565.30 & Q5TLE8_MOUSE & & \\
\hline 93 & $\begin{array}{c}\text { PDZ domain-containing protein } 1 \\
\text { - Mus musculus (Mouse) }\end{array}$ & 65 & 19 & 56862.78 & PDZD1_MOUSE & \multirow{2}{*}{ Q9JIL4 } & \multirow{2}{*}{33} \\
\hline 94 & PDZ domain-containing protein 1 & 72 & 34 & 56862.78 & PDZD1_MOUSE & & \\
\hline
\end{tabular}




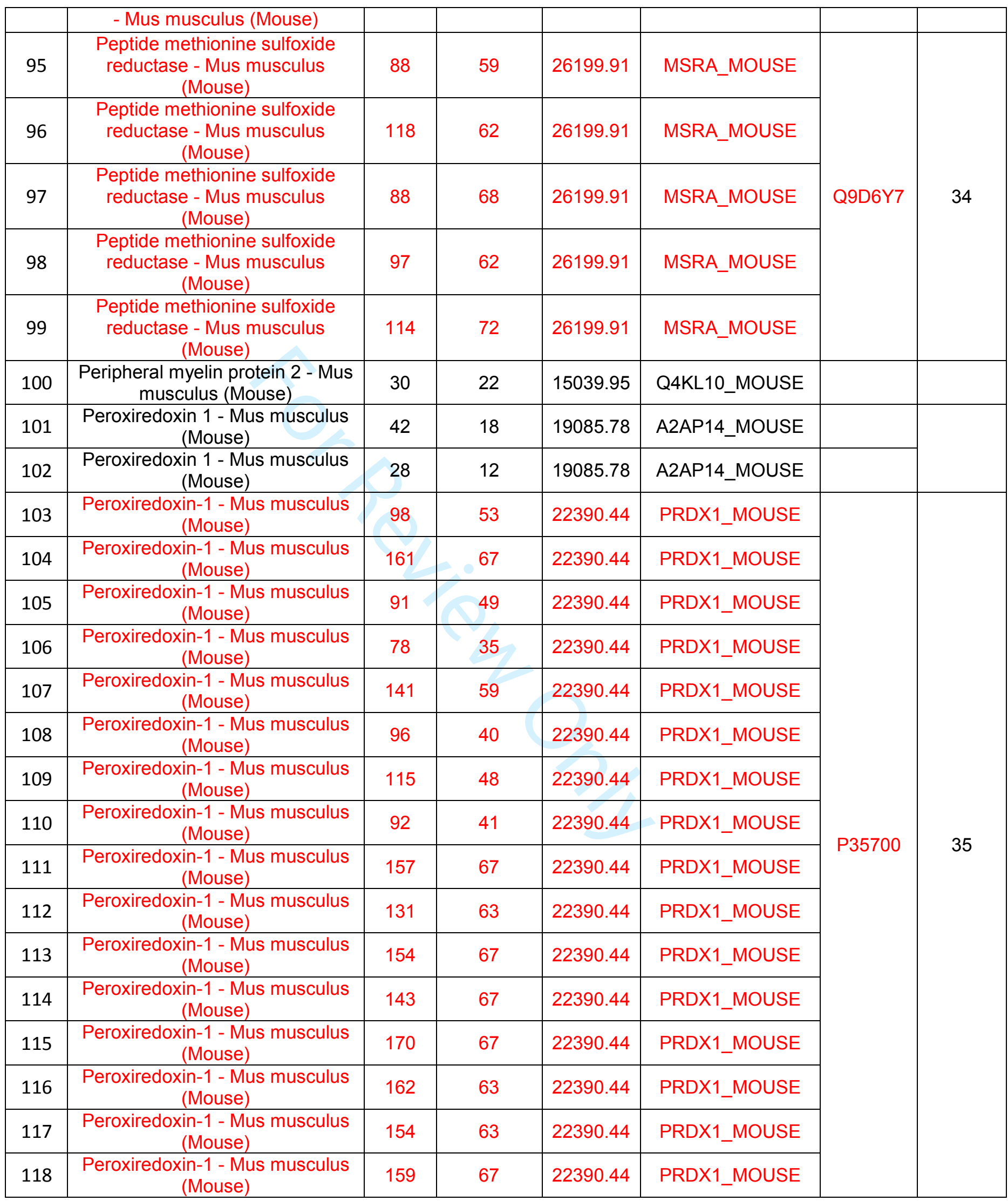




\begin{tabular}{|c|c|c|c|c|c|c|c|}
\hline 119 & $\begin{array}{l}\text { Peroxiredoxin-1 - Mus musculus } \\
\text { (Mouse) }\end{array}$ & 177 & 67 & 22390.44 & PRDX1_MOUSE & & \\
\hline 120 & $\begin{array}{l}\text { Peroxiredoxin-1 - Mus musculus } \\
\text { (Mouse) }\end{array}$ & 175 & 67 & 22390.44 & PRDX1_MOUSE & & \\
\hline 121 & $\begin{array}{c}\text { Peroxiredoxin-1 - Mus musculus } \\
\text { (Mouse) }\end{array}$ & 180 & 63 & 22390.44 & PRDX1_MOUSE & & \\
\hline 122 & $\begin{array}{c}\text { Peroxiredoxin-2 - Mus musculus } \\
\text { (Mouse) }\end{array}$ & 58 & 22 & 21936.12 & PRDX2_MOUSE & \multirow{5}{*}{ Q61171 } & \multirow{5}{*}{36} \\
\hline 123 & $\begin{array}{c}\text { Peroxiredoxin-2 - Mus musculus } \\
\text { (Mouse) }\end{array}$ & 68 & 45 & 21936.12 & PRDX2_MOUSE & & \\
\hline 124 & $\begin{array}{c}\text { Peroxiredoxin-2 - Mus musculus } \\
\text { (Mouse) }\end{array}$ & 99 & 55 & 21936.12 & PRDX2_MOUSE & & \\
\hline 125 & $\begin{array}{c}\text { Peroxiredoxin-2 - Mus musculus } \\
\text { (Mouse) }\end{array}$ & 73 & 36 & 21936.12 & PRDX2_MOUSE & & \\
\hline 126 & $\begin{array}{c}\text { Peroxiredoxin-2 - Mus musculus } \\
\text { (Mouse) }\end{array}$ & 67 & 24 & 21936.12 & PRDX2_MOUSE & & \\
\hline 127 & $\begin{array}{c}\text { Peroxiredoxin-4 - Mus musculus } \\
\text { (Mouse) }\end{array}$ & 129 & 63 & 31261.23 & PRDX4_MOUSE & 008807 & 37 \\
\hline 128 & $\begin{array}{l}\text { Peroxiredoxin-5, mitochondrial } \\
\text { precursor - Mus musculus } \\
\text { (Mouse) }\end{array}$ & 102 & 37 & 22225.67 & PRDX5_MOUSE & \multirow{5}{*}{ P99029 } & \multirow{5}{*}{38} \\
\hline 129 & $\begin{array}{l}\text { Peroxiredoxin-5, mitochondrial } \\
\text { precursor - Mus musculus } \\
\text { (Mouse) }\end{array}$ & 58 & 24 & 22225.67 & PRDX5_MOUSE & & \\
\hline 130 & $\begin{array}{l}\text { Peroxiredoxin-5, mitochondrial } \\
\text { precursor - Mus musculus } \\
\text { (Mouse) }\end{array}$ & 116 & & 22225.67 & PRDX5_MOUSE & & \\
\hline 131 & $\begin{array}{l}\text { Peroxiredoxin-5, mitochondrial } \\
\text { precursor - Mus musculus } \\
\text { (Mouse) }\end{array}$ & 147 & 46 & 22225.67 & PRDX5_MOUSE & & \\
\hline 132 & $\begin{array}{l}\text { Peroxiredoxin-5, mitochondrial } \\
\text { precursor - Mus musculus } \\
\text { (Mouse) }\end{array}$ & 147 & 45 & 22225.67 & PRDX5_MOUSE & & \\
\hline 133 & $\begin{array}{c}\text { Peroxiredoxin-6 - Mus musculus } \\
\text { (Mouse) }\end{array}$ & 104 & 66 & 24969.02 & PRDX6_MOUSE & \multirow{4}{*}{008709} & \multirow{4}{*}{39} \\
\hline 134 & $\begin{array}{l}\text { Peroxiredoxin-6 - Mus musculus } \\
\text { (Mouse) }\end{array}$ & 100 & 52 & 24969.02 & PRDX6_MOUSE & & \\
\hline 135 & $\begin{array}{l}\text { Peroxiredoxin-6 - Mus musculus } \\
\text { (Mouse) }\end{array}$ & 95 & 45 & 24969.02 & PRDX6_MOUSE & & \\
\hline 136 & $\begin{array}{c}\text { Peroxiredoxin-6 - Mus musculus } \\
\text { (Mouse) }\end{array}$ & 69 & 27 & 24969.02 & PRDX6_MOUSE & & \\
\hline 137 & $\begin{array}{l}\text { Peroxisomal bifunctional enzyme } \\
\text { - Mus musculus (Mouse) }\end{array}$ & 77 & 15 & 78764.23 & ECHP_MOUSE & Q9DBM2 & 40 \\
\hline 138 & $\begin{array}{c}\text { Prdx2 protein - Mus musculus } \\
\text { (Mouse) }\end{array}$ & 37 & 22 & 21948.16 & Q5M9N9_MOUSE & & \\
\hline 139 & $\begin{array}{c}\text { Prdx2 protein - Mus musculus } \\
\text { (Mouse) }\end{array}$ & 43 & 22 & 21948.16 & Q5M9N9_MOUSE & & \\
\hline 140 & $\begin{array}{c}\text { Probable D-lactate } \\
\text { dehydrogenase, mitochondrial } \\
\text { precursor - Mus musculus } \\
\text { (Mouse) }\end{array}$ & 192 & 54 & 52499.42 & LDHD_MOUSE & \multirow{2}{*}{ Q7TNG8 } & \multirow{2}{*}{41} \\
\hline 141 & $\begin{array}{c}\text { Probable D-lactate } \\
\text { dehydrogenase, mitochondrial } \\
\text { precursor - Mus musculus } \\
\text { (Mouse) }\end{array}$ & 96 & 32 & 52499.42 & LDHD_MOUSE & & \\
\hline
\end{tabular}




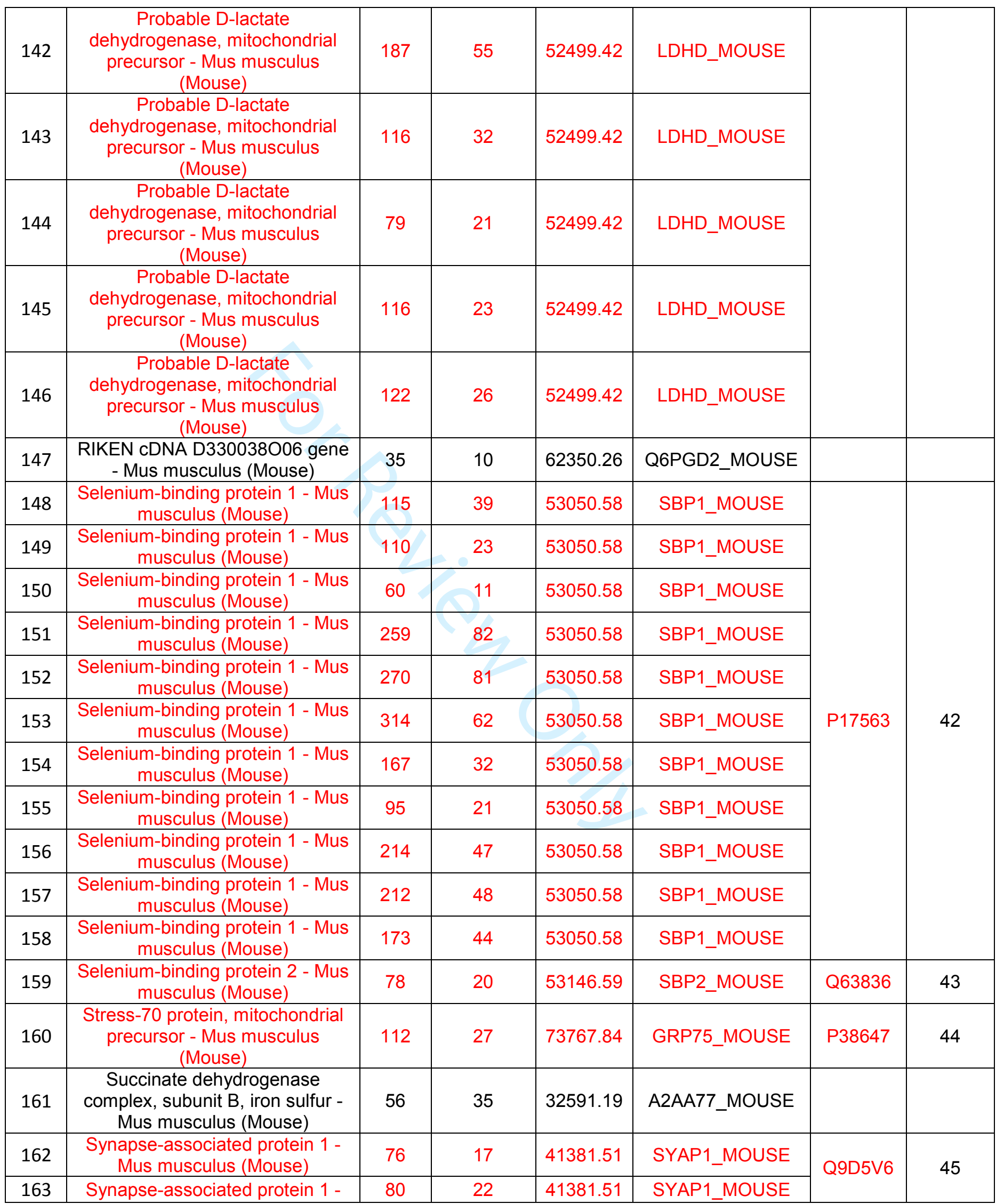




\begin{tabular}{|c|c|c|c|c|c|c|c|}
\hline & Mus musculus (Mouse) & & & & & & \\
\hline 164 & $\begin{array}{l}\text { Thioredoxin domain-containing } \\
\text { protein } 4 \text { precursor - Mus } \\
\text { musculus (Mouse) }\end{array}$ & 97 & 35 & 47222.45 & TXND4_MOUSE & Q9D1Q6 & 46 \\
\hline 165 & $\begin{array}{c}\text { Thioredoxin-dependent peroxide } \\
\text { reductase, mitochondrial } \\
\text { precursor - Mus musculus } \\
\text { (Mouse) } \\
\end{array}$ & 76 & 44 & 28337.49 & PRDX3_MOUSE & \multirow{2}{*}{ P20108 } & \multirow{2}{*}{47} \\
\hline 166 & $\begin{array}{c}\text { Thioredoxin-dependent peroxide } \\
\text { reductase, mitochondrial } \\
\text { precursor - Mus musculus } \\
\text { (Mouse) }\end{array}$ & 61 & 36 & 28337.49 & PRDX3_MOUSE & & \\
\hline 167 & $\begin{array}{c}\text { Tubulin alpha-4A chain - Mus } \\
\text { musculus (Mouse) }\end{array}$ & 138 & 41 & 50633.65 & TBA4A_MOUSE & P68368 & 48 \\
\hline 168 & $\begin{array}{l}\text { Twinfilin-1 - Mus musculus } \\
\text { (Mouse) }\end{array}$ & 86 & 33 & 40282.56 & TWF1_MOUSE & \multirow{2}{*}{ Q91YR1 } & \multirow{2}{*}{49} \\
\hline 169 & $\begin{array}{c}\text { Twinfilin-1 - Mus musculus } \\
\text { (Mouse) }\end{array}$ & 92 & 35 & 40282.56 & TWF1_MOUSE & & \\
\hline 170 & $\begin{array}{l}\text { Wiscott-Aldrich Syndrome } \\
\text { protein homolog - Mus musculus } \\
\text { (Mouse) }\end{array}$ & 39 & 10 & 54568.45 & Q61078_MOUSE & & \\
\hline 171 & $\begin{array}{l}\text { Ywhaq protein - Mus musculus } \\
\text { (Mouse) }\end{array}$ & 50 & 28 & 28045.89 & A3KML3_MOUSE & & \\
\hline
\end{tabular}

Table 1.9: mass spec analysis of a 2D gel of an acid-eluted fraction from a mitochondrial lysate from mouse brains.

\begin{tabular}{|c|c|c|c|c|c|c|c|}
\hline $\begin{array}{c}\text { Spot } \\
\#\end{array}$ & Protein species & $\begin{array}{l}\text { Protein } \\
\text { MW }\end{array}$ & $\begin{array}{l}\text { Mascot } \\
\text { Score }\end{array}$ & $\begin{array}{c}\% \\
\text { Coverage }\end{array}$ & Accession & $\begin{array}{c}\text { Uniprot } \\
\text { ID }\end{array}$ & $\begin{array}{c}\text { \# of } \\
\text { species }\end{array}$ \\
\hline 3 & $\begin{array}{l}\text { ATP synthase subunit } \\
\text { alpha, mitochondrial }\end{array}$ & 59830 & 79 & 29 & ATPA_MOUSE & \multirow{5}{*}{ Q03265 } & \multirow{5}{*}{1} \\
\hline 4 & $\begin{array}{l}\text { ATP synthase subunit } \\
\text { alpha, mitochondrial }\end{array}$ & 59830 & 92 & 34 & ATPA_MOUSE & & \\
\hline 5 & $\begin{array}{l}\text { ATP synthase subunit } \\
\text { alpha, mitochondrial }\end{array}$ & 59830 & 199 & 55 & ATPA_MOUSE & & \\
\hline 6 & $\begin{array}{l}\text { ATP synthase subunit } \\
\text { alpha, mitochondrial }\end{array}$ & 59830 & 228 & 58 & ATPA_MOUSE & & \\
\hline 7 & $\begin{array}{l}\text { ATP synthase subunit } \\
\text { alpha, mitochondrial }\end{array}$ & 59830 & 41 & 20 & ATPA_MOUSE & & \\
\hline 8 & $\begin{array}{c}\text { ATP synthase subunit beta, } \\
\text { mitochondrial }\end{array}$ & 56265 & 216 & 64 & ATPB_MOUSE & P564804 & 2 \\
\hline 9 & $\begin{array}{c}\text { ATP synthase subunit d, } \\
\text { mitochondrial }\end{array}$ & 18795 & 66 & 63 & ATP5H_MOUSE & Q9DCX2 & 3 \\
\hline 10 & $\begin{array}{l}\text { Cytochrome b-c1 complex } \\
\text { subunit Rieske, } \\
\text { mitochondrial }\end{array}$ & 53446 & 47 & 27 & UCRI_MOUSE & Q9CR68 & 4 \\
\hline 20 & $\begin{array}{c}\text { Glyceraldehyde-3- } \\
\text { phosphate dehydrogenase }\end{array}$ & 36072 & 152 & 50 & G3P_MOUSE & P16858 & 5 \\
\hline 21 & $\begin{array}{c}\text { Glyceraldehyde-3- } \\
\text { phosphate dehydrogenase }\end{array}$ & 36072 & 110 & 56 & G3P_MOUSE & P16858 & 3 \\
\hline
\end{tabular}




\begin{tabular}{|c|c|c|c|c|c|c|c|}
\hline 26 & $\begin{array}{c}\text { Isocitrate dehydrogenase } \\
\text { [NAD] subunit gamma 1, } \\
\text { mitochondrial }\end{array}$ & 43157 & 42 & 25 & IDHG1_MOUSE & P70404 & 6 \\
\hline 27 & $\begin{array}{c}\text { NADH dehydrogenase } \\
\text { [ubiquinone] iron-sulfur } \\
\text { protein 2, mitochondrial }\end{array}$ & 52991 & 51 & 25 & NDUS2_MOUSE & Q91WD5 & 7 \\
\hline $\begin{array}{c}\text { NADH dehydrogenase } \\
\text { [ubiquinone] iron-sulfur } \\
\text { protein 3, mitochondrial }\end{array}$ & 30302 & 161 & 60 & NDUS3_MOUSE & Q9DCT2 & 8 \\
\hline $\begin{array}{c}\text { Pyruvate dehydrogenase } \\
\text { E1 component subunit beta, } \\
\text { mitochondrial }\end{array}$ & 39254 & 90 & 47 & ODPB_MOUSE & Q9D051 & 9 \\
\hline
\end{tabular}

Table 1.10: mass spec analysis of a 2D gel of a DTT-eluted fraction from a mitochondrial lysate from mouse brains. The analysis is for the proteins remaining on the affinity column immediately after acidic elution took place.

\begin{tabular}{|c|c|c|c|c|c|c|c|}
\hline $\begin{array}{c}\text { Spot } \\
\#\end{array}$ & Protein species & $\begin{array}{l}\text { Protein } \\
\text { MW }\end{array}$ & $\begin{array}{c}\text { Mascot } \\
\text { Score }\end{array}$ & $\begin{array}{c}\% \\
\text { Coverage }\end{array}$ & Accession & $\begin{array}{l}\text { Uniprot } \\
\text { ID }\end{array}$ & $\begin{array}{c}\text { \# of } \\
\text { species }\end{array}$ \\
\hline 10 & $\begin{array}{l}\text { ATP synthase subunit } \\
\text { alpha, mitochondrial }\end{array}$ & 59830 & 184 & 55 & ATPA_MOUSE & Q03265 & 1 \\
\hline 11 & $\begin{array}{l}\text { ATP synthase subunit } \\
\text { beta, mitochondrial }\end{array}$ & 56265 & 108 & 57 & ATPB_MOUSE & \multirow{2}{*}{ P564804 } & \multirow[t]{2}{*}{2} \\
\hline 12 & $\begin{array}{l}\text { ATP synthase subunit } \\
\text { beta, mitochondrial }\end{array}$ & 56265 & 158 & 67 & ATPB_MOUSE & & \\
\hline 13 & $\begin{array}{c}\text { ATP synthase subunit d, } \\
\text { mitochondrial }\end{array}$ & 18795 & 51 & 54 & ATP5H_MOUSE & Q9DCX2 & 3 \\
\hline 16 & $\begin{array}{l}\text { Cytochrome b-c1 } \\
\text { complex subunit } 1 \text {, } \\
\text { mitochondrial }\end{array}$ & 53446 & 132 & 37 & UCRI_MOUSE & Q9CR68 & 4 \\
\hline 20 & $\begin{array}{l}\text { Glyceraldehyde-3- } \\
\text { phosphate } \\
\text { dehydrogenase }\end{array}$ & 36072 & 76 & 33 & G3P_MOUSE & \multirow{3}{*}{ P16858 } & \multirow{3}{*}{5} \\
\hline 21 & $\begin{array}{l}\text { Glyceraldehyde-3- } \\
\text { phosphate } \\
\text { dehydrogenase }\end{array}$ & 36072 & 132 & 43 & G3P_MOUSE & & \\
\hline 22 & $\begin{array}{c}\text { Glyceraldehyde-3- } \\
\text { phosphate } \\
\text { dehydrogenase }\end{array}$ & 36072 & 109 & 41 & G3P_MOUSE & & \\
\hline 25 & $\begin{array}{c}\text { Isocitrate dehydrogenase } \\
\text { [NAD] subunit alpha, } \\
\text { mitochondrial }\end{array}$ & 40069 & 50 & 26 & IDH3A_MOUSE & Q9D6R2 & 6 \\
\hline 26 & Peroxiredoxin-1 & 22390 & 103 & 57 & PRDX1_MOUSE & \multirow{2}{*}{ P35700 } & \multirow{2}{*}{7} \\
\hline 27 & Peroxiredoxin-1 & 22390 & 185 & 74 & PRDX1_MOUSE & & \\
\hline 28 & Peroxiredoxin-2 & 21936 & 121 & 53 & PRDX2_MOUSE & Q61171 & 8 \\
\hline 29 & Peroxiredoxin-4 & 31261 & 55 & 30 & PRDX4_MOUSE & 008807 & 9 \\
\hline 30 & Peroxiredoxin-6 & 24969 & 36 & 24 & PRDX6_MOUSE & O08709 & 10 \\
\hline 31 & $\begin{array}{c}\text { Pyruvate dehydrogenase } \\
\text { E1 component subunit } \\
\text { beta, mitochondrial }\end{array}$ & 39254 & 150 & 64 & ODPB_MOUSE & Q9D051 & 11 \\
\hline
\end{tabular}


Table 1.12: mass spec analysis of a 1D gel of a DTT-eluted fraction fraction from a mitochondrial lysate derived from mouse hearts. The analysis is for the proteins remaining on the affinity column after acidic elution.

\begin{tabular}{|c|c|c|c|c|c|c|c|}
\hline $\begin{array}{c}\text { Band } \\
\#\end{array}$ & Protein species & Accession & $\begin{array}{c}\text { Uniprot } \\
\text { ID }\end{array}$ & $\begin{array}{c}\text { Mascot } \\
\text { Score }\end{array}$ & $\begin{array}{c}\text { \% } \\
\text { Coverage }\end{array}$ & $\begin{array}{c}\text { Protein } \\
\text { MW }\end{array}$ & $\begin{array}{c}\text { \# of } \\
\text { species }\end{array}$ \\
\hline 1 & $\begin{array}{c}\text { ATP synthase subunit beta, } \\
\text { mitochondrial OS=Mus } \\
\text { musculus GN= }\end{array}$ & ATPB_MOUSE & P56480 & 67 & 23 & 56265.00 & 1 \\
\hline 2 & $\begin{array}{c}\text { Edem3 protein (Fragment) } \\
\text { OS=Mus musculus } \\
\text { GN=Edem3 PE=2 SV=1 }\end{array}$ & Q8R1X5_MOUSE & Q8R1X5 & 33 & 35 & 6066.00 & 2 \\
\hline 3 & $\begin{array}{c}\text { Keratin 15 OS=Mus } \\
\text { musculus GN=Krt15 PE=3 } \\
\text { SV=1 }\end{array}$ & B1AQ77_MOUSE & B1AQ77 & 35 & 18 & 49463.00 & 3 \\
\hline 4 & $\begin{array}{c}\text { Putative uncharacterized } \\
\text { protein (Fragment) OS=Mus } \\
\text { musculus }\end{array}$ & Q3UWR0_MOUSE & Q3UWR0 & 39 & 36 & 21988.00 & 4 \\
\hline 5 & $\begin{array}{c}\text { Putative uncharacterized } \\
\text { protein OS=Mus musculus } \\
\text { GN=Zfp809 P }\end{array}$ & Q8BIL4_MOUSE & Q8BIL4 & 33 & 33 & 19729.00 & 5 \\
\hline 6 & $\begin{array}{c}\text { Rac GTPase-activating } \\
\text { protein 1 }\end{array}$ & E9Q851_MOUSE & E9Q851 & 34 & 41 & 15467.00 & 6 \\
\hline
\end{tabular}

Table 1.13: mass spec analysis of a 1D gel of a DTT-eluted fraction from a mitochondrial lysate derived from mouse skeletal muscles. The analysis is for the proteins remaining on the affinity column after acidic elution.

\begin{tabular}{|c|c|c|c|c|c|c|c|}
\hline $\begin{array}{c}\text { Band } \\
\#\end{array}$ & Protein species & Accession & $\begin{array}{c}\text { Uniprot } \\
\text { ID }\end{array}$ & $\begin{array}{c}\text { Mascot } \\
\text { Score }\end{array}$ & $\begin{array}{c}\text { \% } \\
\text { Coverage }\end{array}$ & $\begin{array}{c}\text { Protein } \\
\text { MW }\end{array}$ & $\begin{array}{c}\text { \# of } \\
\text { species }\end{array}$ \\
\hline 1 & $\begin{array}{c}\text { ATP synthase subunit alpha, } \\
\text { mitochondrial OS=Mus } \\
\text { musculus GN }\end{array}$ & ATPA_MOUSE & Q03265 & 107 & 16 & 59716.00 & 1 \\
\hline 2 & $\begin{array}{c}\text { Keratin 15 OS=Mus musculus } \\
\text { GN=Krt15 PE=3 SV=1 }\end{array}$ & B1AQ77_MOUSE & B1AQ77 & 56 & 23 & 49463.00 & 2 \\
\hline 3 & $\begin{array}{c}\text { Sarcoplasmic/endoplasmic } \\
\text { reticulum calcium ATPase 1 } \\
\text { OS=Mus m }\end{array}$ & AT2A1_MOUSE & Q8R429 & 63 & 6 & 109355.00 & 3 \\
\hline 4 & RNA-binding protein 39 & D6RJ85_MOUSE & D6RJ85 & 33 & 43 & 6953.00 & 4 \\
\hline
\end{tabular}


Supplementary tables 2. Interactors of Trx2 as identified by the proteomics and Y2H screens including those currently available in BioGRID.

Supplementary table 2.1. Cumulative protein interactions of mouse Trx2 as detected by acidic (“Acid") and DTT elutions ("DTT") in extracts from different mouse tissues. The table represents the combined data from all experiments with mitochondrial and total cell lysates. All proteins highlighted in green are of mitochondrial localization according to MitoCarta2.0. The DTT elutions in skeletal muscle correspond to two different experiments for total cell lysates (DTT 1, 2, analyzed by 2D electrophoresis) and an experiment where mitochondrial lysates were examined (DTT m, analyzed by 1D SDS PAGE). Cardiac and brain mitochondrial lysates (designation "m") were analyzed by 1D and 2D electrophoresis respectively. The raw data for this table are presented in Supplementary tables 1.1-1.13. Total tissue hits (right column) were calculated by the sum of each protein species detected in different tissues by Acid or DTT elutions. In the case of the DTT elutions of the skeletal muscle experiments (three columns), the respective interactome was calculated as the sum of all detected protein species and was considered as a single experiment (one column) in the calculation of total tissue hits.

\begin{tabular}{|c|c|c|c|c|c|c|c|c|c|c|c|c|c|c|c|}
\hline \multirow{2}{*}{$\begin{array}{c}\text { \# of } \\
\text { protein } \\
\text { species }\end{array}$} & \multirow{2}{*}{$\begin{array}{l}\text { Uniprot } \\
\text { ID }\end{array}$} & \multirow{2}{*}{ Protein species } & \multicolumn{2}{|c|}{ Lung } & \multicolumn{4}{|c|}{ Skeletal muscle } & \multicolumn{2}{|c|}{ Kidney } & \multicolumn{2}{|c|}{$\begin{array}{l}\text { Cardiac } \\
\text { muscle }\end{array}$} & \multicolumn{2}{|c|}{ Brain } & \multirow{2}{*}{$\begin{array}{c}\text { Total \# of } \\
\text { tissues hits } \\
\text { per elution } \\
\text { per protein } \\
\text { species }\end{array}$} \\
\hline & & & Acid & DTT & Acid & $\begin{array}{c}\text { DTT } \\
1\end{array}$ & $\begin{array}{c}\text { DTT } \\
2\end{array}$ & $\begin{array}{c}\text { DTT } \\
\mathbf{m}\end{array}$ & Acid & DTT & $\begin{array}{c}\text { Acid } \\
\mathbf{m}\end{array}$ & $\begin{array}{c}\text { DTT } \\
\mathrm{m}\end{array}$ & $\begin{array}{c}\text { Acid } \\
\mathbf{m}\end{array}$ & $\begin{array}{l}\text { DTT } \\
\mathrm{m}\end{array}$ & \\
\hline 1 & P56480 & $\begin{array}{l}\text { ATP synthase subunit beta, } \\
\text { mitochondrial }\end{array}$ & + & & + & & + & & + & & & + & + & + & 7 \\
\hline 2 & Q61171 & Peroxiredoxin-2 & + & + & & + & & 8 & + & + & & & & + & 6 \\
\hline 3 & Q03265 & $\begin{array}{l}\text { ATP synthase subunit alpha, } \\
\text { mitochondrial }\end{array}$ & + & & + & + & & + & & & + & & + & + & 6 \\
\hline 4 & 008553 & $\begin{array}{c}\text { Dihydropyrimidinase-related } \\
\text { protein } 2\end{array}$ & & + & & & & & + & + & & & + & + & 5 \\
\hline 5 & P16858 & $\begin{array}{c}\text { Glyceraldehyde-3-phosphate } \\
\text { dehydrogenase }\end{array}$ & + & & + & + & + & & & & & & + & + & 5 \\
\hline 6 & P17182 & Alpha-enolase & + & + & & & & & & + & & & & + & 4 \\
\hline 7 & P35700 & Peroxiredoxin-1 & & + & & + & + & & & + & & & & + & 4 \\
\hline 8 & 008807 & Peroxiredoxin-4 & + & + & & & & & & + & & & & + & 4 \\
\hline 9 & 008709 & Peroxiredoxin-6 & & + & & + & & & & + & & & & + & 4 \\
\hline 10 & P63038 & $60 \mathrm{kDa}$ heat shock protein, & & & & + & + & & & + & & & & + & 3 \\
\hline
\end{tabular}




\begin{tabular}{|c|c|c|c|c|c|c|c|c|c|c|c|c|c|c|}
\hline & & mitochondrial & & & & & & & & & & & & \\
\hline 11 & P60710 & Actin, cytoplasmic 1 & + & & & & & & & & & + & + & 3 \\
\hline 12 & P53996 & $\begin{array}{c}\text { Cellular nucleic acid-binding } \\
\text { protein }\end{array}$ & & + & & + & + & & & + & & & & 3 \\
\hline 13 & P02088 & Hemoglobin subunit beta-1 & & + & & + & + & & & + & & & & 3 \\
\hline 14 & Q7TMM9 & Tubulin beta-2A chain & + & & & & & & & & & + & + & 3 \\
\hline 15 & P17563 & $\begin{array}{c}\text { Methanethiol oxidase/ } \\
\text { Se-binding protein } 1 \\
\end{array}$ & & + & & & & & & + & & & & 2 \\
\hline 16 & O35226 & $\begin{array}{l}\text { 26S proteasome non-ATPase } \\
\text { regulatory subunit } 4\end{array}$ & & + & & & + & & & & & & & 2 \\
\hline 17 & Q99KIO & $\begin{array}{c}\text { Aconitate hydratase, } \\
\text { mitochondrial }\end{array}$ & & & & & + & & & + & & & & 2 \\
\hline 18 & P62737 & Actin, aortic smooth muscle & & 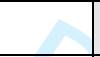 & + & & + & & & & & & & 2 \\
\hline 19 & Q9R0Y5 & Adenylate kinase isoenzyme 1 & & 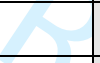 & & + & + & & & + & & & & 2 \\
\hline 20 & P47738 & $\begin{array}{l}\text { Aldehyde dehydrogenase, } \\
\text { mitochondrial }\end{array}$ & + & 4 & & 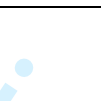 & & & + & & & & & 2 \\
\hline 21 & P23927 & Alpha-crystallin B chain & + & & + & 2 & & & & & & & & 2 \\
\hline 22 & P07356 & Annexin A2 & & + & & + & & & & + & & & & 2 \\
\hline 23 & Q9DCX2 & $\begin{array}{l}\text { ATP synthase subunit d, } \\
\text { mitochondrial }\end{array}$ & & & & & & & & & & + & + & 2 \\
\hline 24 & P21550 & Beta-enolase & & & + & & + & $8=$ & & & & & & 2 \\
\hline 25 & P18760 & Cofilin-1 & & + & & & & +8 & & + & & & & 2 \\
\hline 26 & P56389 & Cytidine deaminase & & & & & & 8 & + & + & & & & 2 \\
\hline 27 & Q9CR68 & $\begin{array}{c}\text { Cytochrome b-c1 complex } \\
\text { subunit Rieske, mitochondrial }\end{array}$ & & & & & & 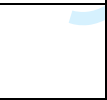 & & & & + & + & 2 \\
\hline 28 & Q9D7X3 & $\begin{array}{c}\text { Dual specificity protein } \\
\text { phosphatase } 3\end{array}$ & & + & & + & + & & & & & & & 2 \\
\hline 29 & P47753 & $\begin{array}{c}\text { F-actin-capping protein } \\
\text { subunit alpha-1 }\end{array}$ & + & & & & & & + & & & & & 2 \\
\hline 30 & P16045 & Galectin-1 & & + & & + & + & & & & & & & 2 \\
\hline 31 & P62874 & $\begin{array}{c}\text { Guanine nucleotide-binding } \\
\text { protein }\end{array}$ & & & & & & & & & & + & + & 2 \\
\hline 32 & B1AQ77 & Keratin 15 & & & & + & & + & & & + & & & 2 \\
\hline
\end{tabular}




\begin{tabular}{|c|c|c|c|c|c|c|c|c|c|c|c|c|c|}
\hline 33 & Q9D154 & Leukocyte elastase inhibitor A & & + & & & & & + & & & & 2 \\
\hline 34 & Q3ULD5 & $\begin{array}{c}\text { Methylcrotonoyl-CoA } \\
\text { carboxylase beta chain, } \\
\text { mitochondrial }\end{array}$ & + & & & & & + & & & & & 2 \\
\hline 35 & Q8VDD5 & Myosin-9 & + & & & & & + & & & & & 2 \\
\hline 36 & Q91WD5 & $\begin{array}{l}\text { NADH dehydrogenase } \\
\text { [ubiquinone] iron-sulfur } \\
\text { protein } 2, \text { mitochondrial }\end{array}$ & & & & & & + & & & + & & 2 \\
\hline 37 & Q91VD9 & $\begin{array}{c}\text { NADH-ubiquinone } \\
\text { oxidoreductase } 75 \mathrm{kDa} \\
\text { subunit, mitochondrial }\end{array}$ & & & & & & + & & + & & & 2 \\
\hline 38 & P99029 & Peroxiredoxin-5, mitochondrial & & & & & & + & + & & & & 2 \\
\hline 39 & Q9D051 & $\begin{array}{l}\text { Pyruvate dehydrogenase E1 } \\
\text { component subunit beta, } \\
\text { mitochondrial }\end{array}$ & & & & & & & & & + & + & 2 \\
\hline 40 & P07724 & Serum albumin & + & + & & 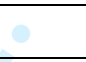 & & & & & & & 2 \\
\hline 41 & P38647 & $\begin{array}{l}\text { Stress-70 protein, } \\
\text { mitochondrial }\end{array}$ & & & & + & + & & + & & & & 2 \\
\hline 42 & Q60864 & $\begin{array}{l}\text { Stress-induced- } \\
\text { phosphoprotein } 1\end{array}$ & & + & & & & & & & & & 2 \\
\hline 43 & Q8K2B3 & $\begin{array}{l}\text { Succinate dehydrogenase } \\
\text { [ubiquinone] flavoprotein } \\
\text { subunit, mitochondrial }\end{array}$ & & & + & & & + & & & & & 2 \\
\hline 44 & Q9D5V6 & Synapse-associated protein 1 & & + & & & & & + & & & & 2 \\
\hline 45 & P20108 & $\begin{array}{l}\text { Thioredoxin-dependent } \\
\text { peroxide reductase, } \\
\text { mitochondrial }\end{array}$ & & & & + & & & + & & & & 2 \\
\hline 46 & P17751 & Triosephosphate isomerase & & & + & + & + & & & & & & 2 \\
\hline 47 & P20152 & Vimentin & + & + & & & & & & & & & 2 \\
\hline 48 & P50516 & $\begin{array}{c}\text { V-type proton ATPase catalytic } \\
\text { subunit A }\end{array}$ & + & & & & & + & & & & & 2 \\
\hline 49 & P62259 & 14-3-3 protein epsilon ( & + & & & & & + & & & & & 2 \\
\hline 50 & Q8K354 & Carbonyl reductase [NADPH] 3 & + & + & & & & & & & & & 2 \\
\hline
\end{tabular}




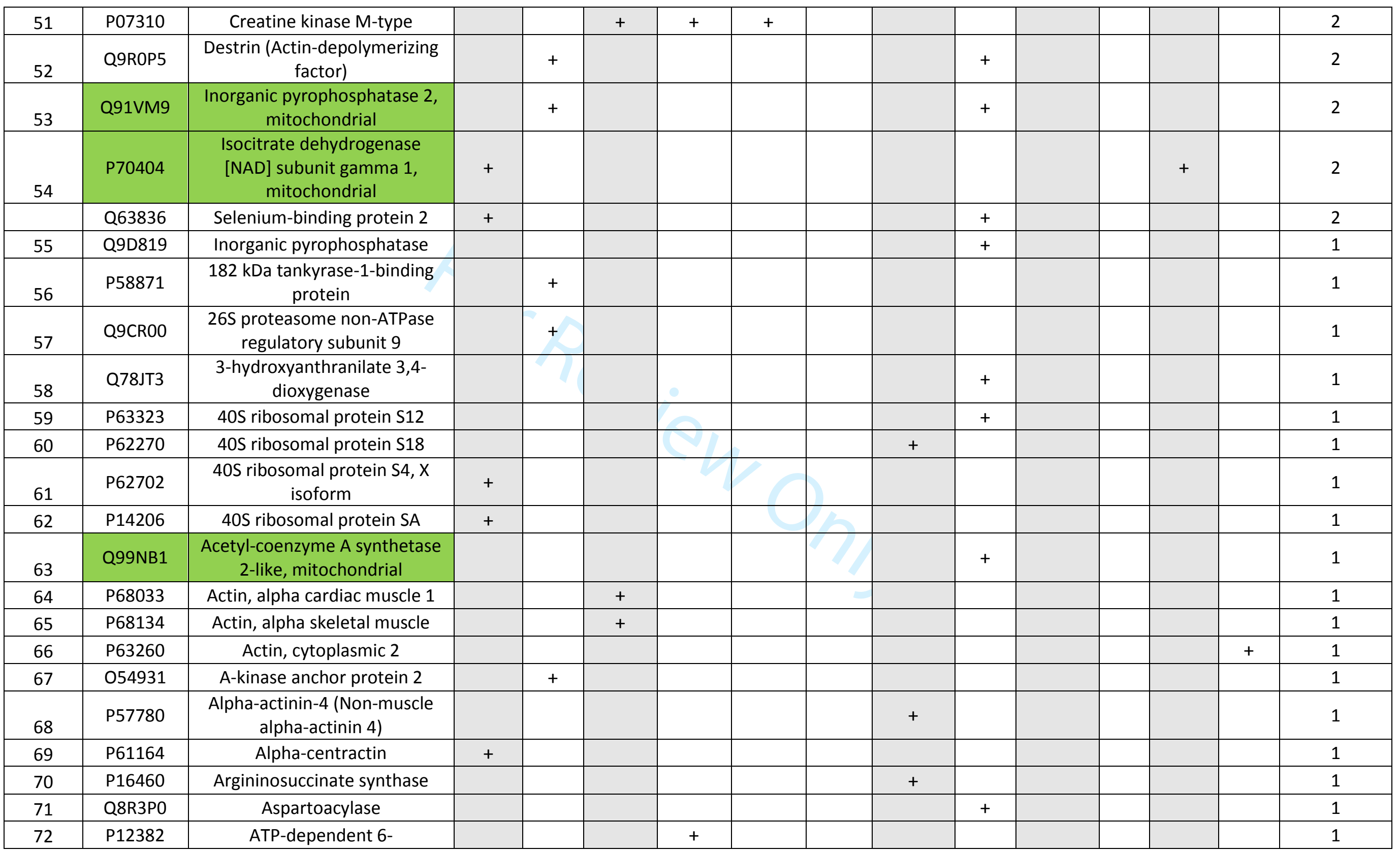




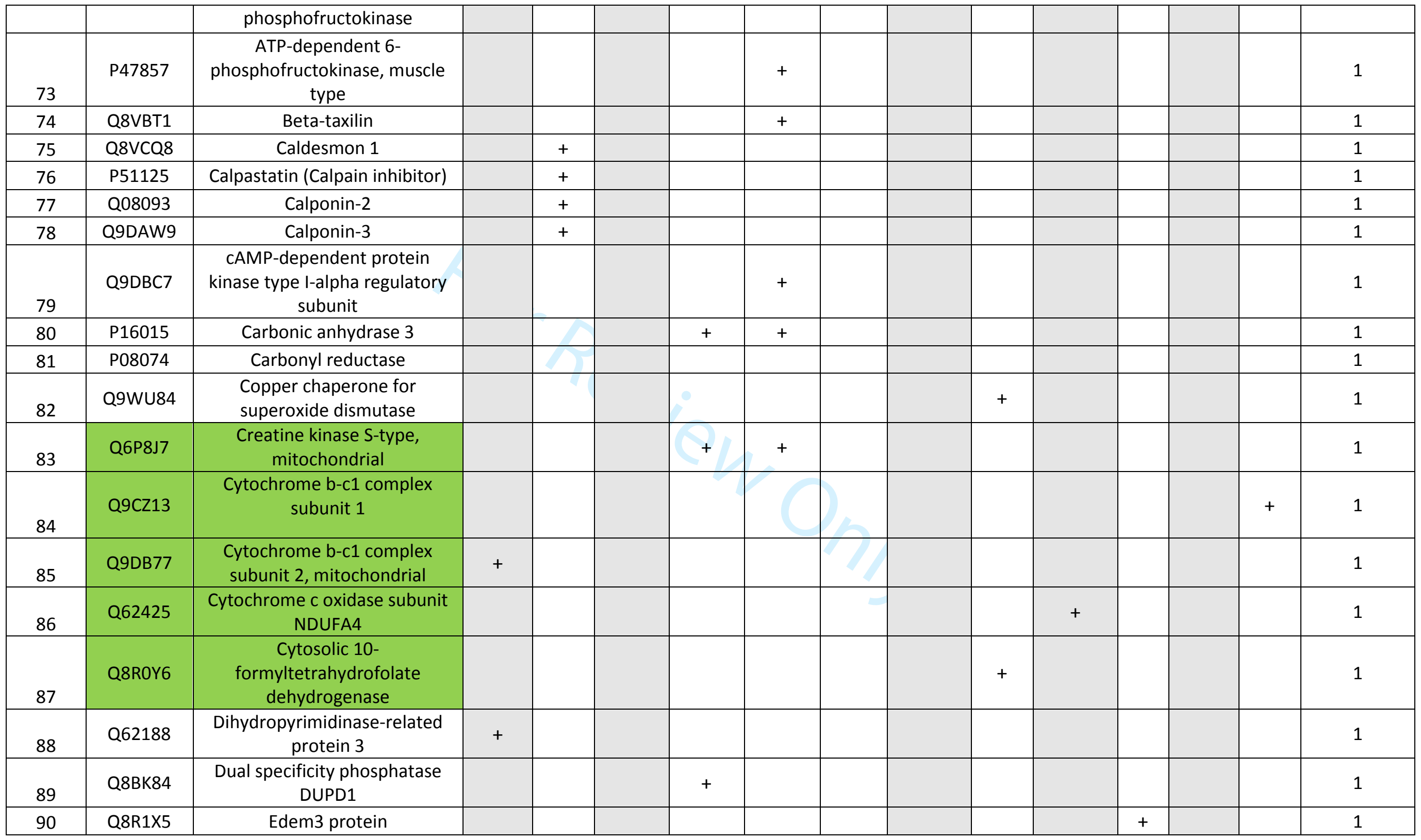




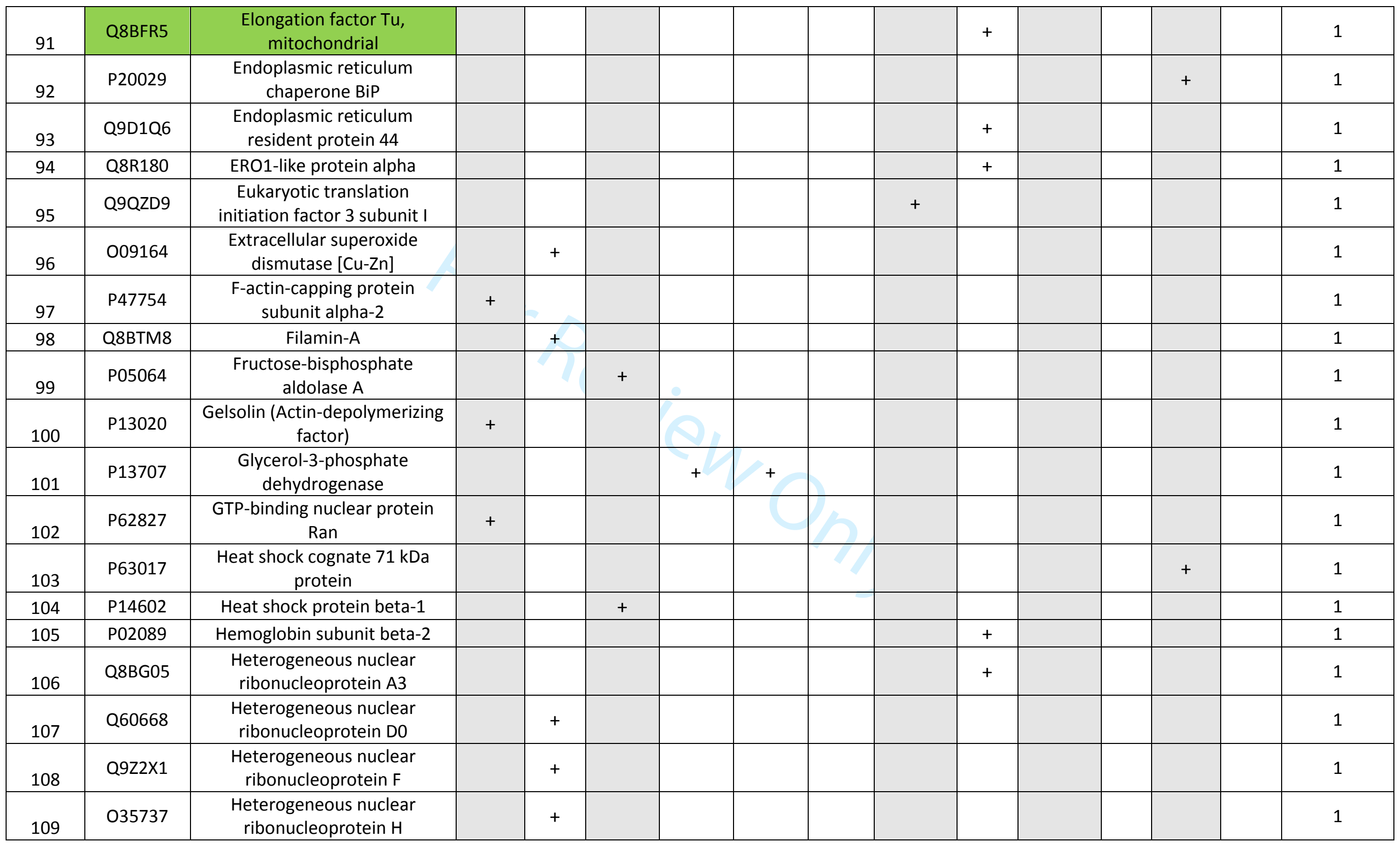




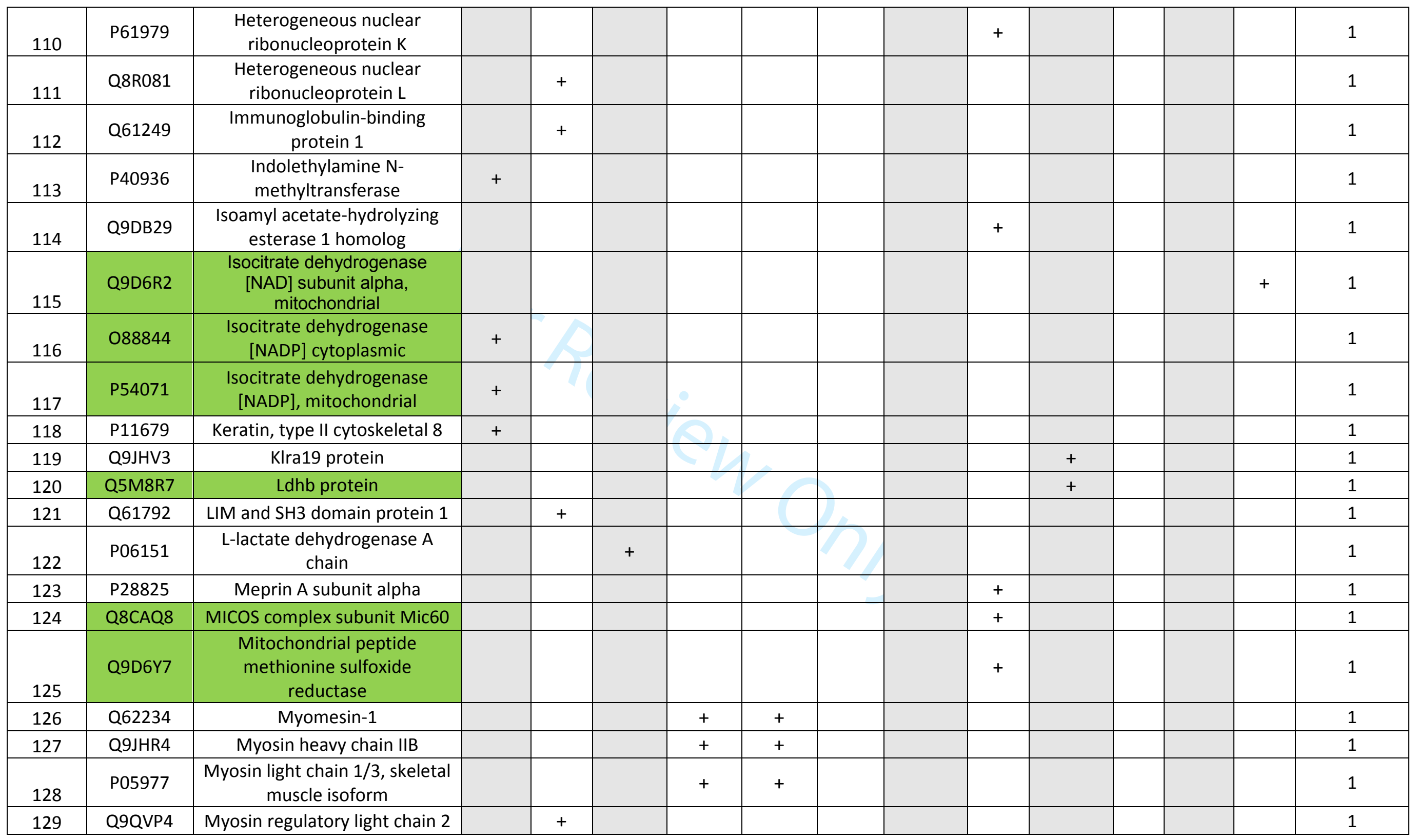




\begin{tabular}{|c|c|c|c|c|c|c|c|c|c|c|c|c|}
\hline 130 & P97457 & $\begin{array}{l}\text { Myosin regulatory light chain } \\
2, \text { skeletal muscle isoform }\end{array}$ & & & & + & + & & & & & 1 \\
\hline 131 & Q5XKE0 & $\begin{array}{l}\text { Myosin-binding protein C, fast- } \\
\text { type }\end{array}$ & & & & + & + & & & & & 1 \\
\hline 132 & P70402 & Myosin-binding protein $\mathrm{H}$ & & & & + & + & & & & & 1 \\
\hline 133 & Q9JIF9 & Myotilin & & & & + & & & & & & 1 \\
\hline 134 & P70441 & $\begin{array}{l}\mathrm{Na}(+) / \mathrm{H}(+) \text { exchange } \\
\text { regulatory cofactor NHE-RF1 }\end{array}$ & & & & & & & + & & & 1 \\
\hline 135 & Q9JHL1 & $\begin{array}{l}\mathrm{Na}(+) / \mathrm{H}(+) \text { exchange } \\
\text { regulatory cofactor NHE-RF2 }\end{array}$ & & + & & & & & & & & 1 \\
\hline 136 & Q9JIL4 & $\begin{array}{l}\mathrm{Na}(+) / \mathrm{H}(+) \text { exchange } \\
\text { regulatory cofactor NHE-RF3 }\end{array}$ & & & & & & & + & & & 1 \\
\hline 137 & Q91XE4 & $\begin{array}{l}\mathrm{N} \text {-acyl-aromatic-L-amino acid } \\
\text { amidohydrolase }\end{array}$ & & & & & & + & & & & 1 \\
\hline 138 & Q91YT0 & $\begin{array}{c}\text { NADH dehydrogenase } \\
\text { [ubiquinone] flavoprotein 1, } \\
\text { mitochondrial }\end{array}$ & & 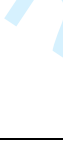 & + & & & & & & & 1 \\
\hline 139 & Q9DCT2 & $\begin{array}{l}\text { NADH dehydrogenase } \\
\text { [ubiquinone] iron-sulfur } \\
\text { protein 3, mitochondrial }\end{array}$ & & & & & & & & & + & 1 \\
\hline 140 & Q6ZWQ0 & Nesprin-2 & & & & & & & & + & & 1 \\
\hline 141 & P11930 & $\begin{array}{l}\text { Nucleoside diphosphate-linked } \\
\text { moiety X motif } 19 \text { (Nudix motif } \\
19 \text { ) }\end{array}$ & & & & & & & + & & & 1 \\
\hline 142 & Q922B1 & $\begin{array}{c}\text { O-acetyl-ADP-ribose } \\
\text { deacetylase MACROD1 }\end{array}$ & & & & + & + & & & & & 1 \\
\hline 143 & Q9DBM2 & $\begin{array}{l}\text { Peroxisomal bifunctional } \\
\text { enzyme }\end{array}$ & & & & & & & + & & & 1 \\
\hline 144 & Q99K51 & Plastin-3 & + & & & & & & & & & 1 \\
\hline 145 & P60335 & Poly(rC)-binding protein 1 & & + & & & & & & & & 1 \\
\hline 146 & Q7TNG8 & $\begin{array}{c}\text { Probable D-lactate } \\
\text { dehydrogenase, mitochondrial }\end{array}$ & & & & & & & + & & & 1 \\
\hline 147 & Q99LX0 & $\begin{array}{l}\text { Protein/nucleic acid deglycase } \\
\text { DJ-1 }\end{array}$ & & & & + & + & & & & & 1 \\
\hline
\end{tabular}




\begin{tabular}{|c|c|c|c|c|c|c|c|c|c|c|c|c|}
\hline 148 & P35486 & $\begin{array}{l}\text { Pyruvate dehydrogenase E1 } \\
\text { component subunit alpha, } \\
\text { somatic form, mitochondrial }\end{array}$ & & & & & & & & & + & 1 \\
\hline 149 & E9Q851 & $\begin{array}{c}\text { Rac GTPase-activating protein } \\
1\end{array}$ & & & & & & & & + & & 1 \\
\hline 150 & Q01730 & Ras suppressor protein 1 & + & & & & & & & & & 1 \\
\hline 151 & P24549 & Retinal dehydrogenase 1 & + & & & & & & & & & 1 \\
\hline 152 & D6RJ85 & RNA-binding protein 39 & & & + & & + & & & & & 1 \\
\hline 153 & Q9WTM5 & RuvB-like 2 & + & & & & & & & & & 1 \\
\hline 154 & Q8R429 & $\begin{array}{l}\text { Sarcoplasmic/endoplasmic } \\
\text { reticulum calcium ATPase } 1\end{array}$ & & & + & & + & & & & & 1 \\
\hline 155 & Q8C1B7 & Septin-11 & + & & & & & & & & & 1 \\
\hline 156 & P42208 & Septin-2 & & 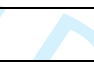 & & & & + & & & & 1 \\
\hline 157 & 055131 & $\begin{array}{l}\text { Septin-7 (CDC10 protein } \\
\text { homolog) }\end{array}$ & + & 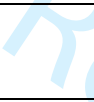 & & & & & & & & 1 \\
\hline 158 & P16546 & $\begin{array}{l}\text { Spectrin alpha chain, non- } \\
\text { erythrocytic } 1\end{array}$ & & & & & & + & & & & 1 \\
\hline 159 & Q60598 & Src substrate cortactin & & + & 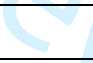 & & & & & & & 1 \\
\hline 160 & Q3UZZ6 & $\begin{array}{c}\text { Sulfotransferase } 1 \text { family } \\
\text { member D1 }\end{array}$ & & & & & & & + & & & 1 \\
\hline 161 & P26039 & Talin-1 & & + & & 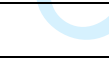 & 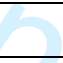 & & & & & 1 \\
\hline 162 & Q8BMS1 & $\begin{array}{l}\text { Trifunctional enzyme subunit } \\
\text { alpha, mitochondrial }\end{array}$ & & + & & & & & & & & 1 \\
\hline 163 & P20801 & $\begin{array}{l}\text { Troponin C, skeletal muscle } \\
\text { (STNC) }\end{array}$ & & & + & + & & & & & & 1 \\
\hline 164 & Q8R112 & Ttn protein & & & + & + & & & & & & 1 \\
\hline 165 & P68368 & Tubulin alpha-4A chain & & & & & & & + & & & 1 \\
\hline 166 & P99024 & Tubulin beta- 5 chain & & & & & & & & & & 1 \\
\hline 167 & Q91YR1 & Twinfilin-1 & & & & & & & + & & & 1 \\
\hline 168 & Q3TW96 & $\begin{array}{l}\text { UDP-N-acetylhexosamine } \\
\text { pyrophosphorylase-like } \\
\text { protein } 1\end{array}$ & & & & & & & + & & & 1 \\
\hline 169 & Q8BRB8 & Uncharacterized protein & & + & & & & & & & & 1 \\
\hline
\end{tabular}




\begin{tabular}{|c|c|c|c|c|c|c|c|c|c|c|c|c|c|}
\hline 170 & Q3UWRO & Uncharacterized protein & & & & & & & & + & & & 1 \\
\hline 171 & Q8BIL4 & Uncharacterized protein & & & & & & & & + & & & 1 \\
\hline 172 & Q8C3W1 & $\begin{array}{c}\text { Uncharacterized protein } \\
\text { C1orf198 homolog }\end{array}$ & & + & & & & & & & & & 1 \\
\hline 173 & P46735 & Unconventional myosin-lb & + & & & & & & & & & & 1 \\
\hline 174 & Q9WTI7 & Unconventional myosin-Ic & + & & & & & & & & & & 1 \\
\hline 175 & Q8VDJ3 & Vigilin & & + & & & & & & & & & 1 \\
\hline 176 & P62814 & $\begin{array}{l}\text { V-type proton ATPase subunit } \\
\text { B, brain isoform }\end{array}$ & & & & & + & & & & & & 1 \\
\hline \multicolumn{3}{|c|}{$\begin{array}{l}\text { Sum of proteins per elution, } \\
\text { of which (mitochondrial species) }\end{array}$} & $\begin{array}{c}40 \\
(12)\end{array}$ & $\begin{array}{l}46 \\
(6)\end{array}$ & $\begin{array}{l}15 \\
(7)\end{array}$ & $\begin{array}{c}43 \\
(12)\end{array}$ & $\begin{array}{l}22 \\
(8)\end{array}$ & $\begin{array}{c}50 \\
(17)\end{array}$ & $\begin{array}{c}6 \\
(4)\end{array}$ & $\begin{array}{c}6 \\
(1)\end{array}$ & $\begin{array}{c}16 \\
(10)\end{array}$ & $\begin{array}{c}19 \\
(12)\end{array}$ & \\
\hline \multicolumn{3}{|c|}{$\begin{array}{c}\text { Common proteins between acidic-DTT elutions, } \\
\text { of which (mitochondrial) }\end{array}$} & \multicolumn{2}{|c|}{$\begin{array}{c}6 \\
(3)\end{array}$} & \multicolumn{2}{|c|}{$\begin{array}{c}7 \\
(5)\end{array}$} & \multicolumn{2}{|c|}{$\begin{array}{c}4 \\
(2)\end{array}$} & & & \multicolumn{2}{|c|}{$\begin{array}{l}10 \\
(6)\end{array}$} & \\
\hline
\end{tabular}

\section{Supplementary Table 2.2. Protein species interacting with Trx2 as revealed by a yeast two hybrid system from a human liver library.}

Proteins highlighted in green are of mitochondrial localization (MitoCarta2.0).

\begin{tabular}{|c|c|c|c|c|}
\hline$\#$ & Uniprot ID & Protein species & $\begin{array}{c}\text { Gene } \\
\text { name }\end{array}$ & $\begin{array}{c}\text { Number of } \\
\text { matches }\end{array}$ \\
\hline 1 & P02675 & Fibrinogen b chain precursor & FGB & 6 \\
\hline 2 & P02679 & Fibrinogen g chain precursor & FGG & 1 \\
\hline 3 & P63261 & g-actin & P63261 & 1 \\
\hline 4 & Q7Z406 & Myosin heavy chain 14 & MYH14 & 10 \\
\hline 5 & P29966 & $\begin{array}{c}\text { Myristoylated alanine rich protein kinase C } \\
\text { substrate (MARCKS) }\end{array}$ & MARCKS & 1 \\
\hline 6 & Q04206 & NF-kB p65 & RELA & 1 \\
\hline 7 & Q14442 & $\begin{array}{c}\text { Phosphatidylinositol N- } \\
\text { acetylglucosaminyltransferase subunit H }\end{array}$ & PIGH & 1 \\
\hline 8 & P00747 & Plasminogen & PLG & 4 \\
\hline
\end{tabular}




\begin{tabular}{|c|c|c|c|c|}
\hline 9 & P07237 & Protein Disulfide Isomerase & P4HB & 1 \\
\hline 10 & Q53ET4 & Serine hydroxymethyl transferase & SHMT1 & 1 \\
\hline 11 & P04004 & Vitronectin, serum spreading factor & VTN & 1 \\
\hline
\end{tabular}

\section{Supplementary Table 2.3. Protein species interacting with Trx2 as revealed by a yeast two hybrid system from a rat brain library.}

Proteins highlighted in green are of mitochondrial localization (MitoCarta2.0).

\begin{tabular}{|c|c|c|c|c|}
\hline$\#$ & Uniprot ID & Protein species & Gene name & $\begin{array}{c}\text { Number of } \\
\text { matches }\end{array}$ \\
\hline 1 & P04644 & 40S ribosomal protein S17 & Rps17 & 1 \\
\hline 2 & P61023 & Calcineurin-like EF-hand protein & Chp1 & 1 \\
\hline 3 & P05503 & $\begin{array}{c}\text { Cytochrome c oxidase subunit 1 } \\
\text { (mitochondrial) }\end{array}$ & Mtco1 & 2 \\
\hline 4 & Q78P75 & Dynein light chain LC8-type 2 (Dynl12) & Dynll2 & 1 \\
\hline 5 & D4A314 & GLIS family Zn finger 3 & Glis3 & 1 \\
\hline 6 & Q00900 & $\begin{array}{c}\text { Human immunodeficiency virus type I } \\
\text { enhancer-binding protein 2 homolog }\end{array}$ & Hivep2 & 1 \\
\hline 7 & Q4JFL8 & $\begin{array}{c}\text { Leukocyte common antigen-related } \\
\text { phosphatase }\end{array}$ & LAR-PTP2 & 1 \\
\hline 8 & & Mitochondrial 16S ribosomal RNA gene & mt-Rnr2 & 1 \\
\hline
\end{tabular}

\section{Supplementary Table 2.4. Protein species interacting with human Trx2 according to BioGRID.}

Proteins highlighted in green are of mitochondrial localization (MitoCarta2.0).

\begin{tabular}{|c|c|c|c|}
\hline$\#$ & UniProtKB & Protein species & Gene name \\
\hline 1 & Q16540 & 39S ribosomal protein L23, mitochondrial (L23mt) (MRP- & MRPL23 \\
\hline 2 & P62249 & 40S ribosomal protein S16 & RPS16 \\
\hline 3 & P62917 & 60S ribosomal protein L8 (Large ribosomal subunit protein & RPL8 \\
\hline
\end{tabular}




\begin{tabular}{|c|c|c|c|}
\hline & & uL2) & \\
\hline 4 & P32969 & $\begin{array}{l}\text { 60S ribosomal protein L9 (Large ribosomal subunit protein } \\
\text { uL6) }\end{array}$ & RPL9 \\
\hline 5 & P08133 & Annexin A6 (67 kDa calelectrin) (Annexin VI) (Annexin-6) & ANXA6 \\
\hline 6 & P63010 & $\begin{array}{l}\text { AP-2 complex subunit beta (AP105B) assembly protein } \\
\text { complex } 2 \text { beta large chain }\end{array}$ & AP2B1 \\
\hline 7 & Q96M63 & Coiled-coil domain-containing protein 114 & CCDC114 \\
\hline 8 & P32321 & Deoxycytidylate deaminase (EC 3.5.4.12) (dCMP deaminase) & DCTD \\
\hline 9 & P40692 & DNA mismatch repair protein Mlh1 (MutL protein homolog 1) & MLH1 \\
\hline 10 & Q9UNE7 & E3 ubiquitin-protein ligase CHIP transferase CHIP & STUB1 \\
\hline 11 & P19474 & E3 ubiquitin-protein ligase TRIM21 & TRIM21 \\
\hline 12 & O95071 & E3 ubiquitin-protein ligase UBR5 & UBR5 \\
\hline 13 & P05062 & $\begin{array}{l}\text { Fructose-bisphosphate aldolase B (EC 4.1.2.13) (Liver-type } \\
\text { aldolase) }\end{array}$ & ALDOB \\
\hline 14 & P04150 & $\begin{array}{l}\text { Glucocorticoid receptor (GR) (Nuclear receptor subfamily } 3 \\
\text { group C member 1) }\end{array}$ & $\mathrm{NR} 3 \mathrm{C} 1$ \\
\hline 15 & O00461 & $\begin{array}{c}\text { Golgi integral membrane protein } 4 \text { (Golgi integral membrane } \\
\text { protein, cis) }\end{array}$ & GOLIM4 \\
\hline 16 & Q96D09 & $\begin{array}{l}\text { G-protein coupled receptor-associated sorting protein } 2 \\
\text { (GASP-2) }\end{array}$ & GPRASP2 \\
\hline 17 & P34931 & $\begin{array}{l}\text { Heat shock } 70 \mathrm{kDa} \text { protein 1-like (Heat shock } 70 \mathrm{kDa} \text { protein } \\
1 \mathrm{~L}) \text { (Heat shock } 70 \mathrm{kDa} \text { protein } 1 \text {-Hom) (HSP70-Hom) }\end{array}$ & HSPA1L \\
\hline 18 & Q9HCE1 & $\begin{array}{l}\text { Helicase MOV-10 (EC 3.6.4.13) (Armitage homolog) } \\
\text { (Moloney leukemia virus } 10 \text { protein) }\end{array}$ & MOV10 \\
\hline 19 & Q12905 & $\begin{array}{c}\text { Interleukin enhancer-binding factor } 2 \text { (Nuclear factor of } \\
\text { activated T-cells } 45 \mathrm{kDa})\end{array}$ & ILF2 \\
\hline 20 & Q12906 & $\begin{array}{l}\text { Interleukin enhancer-binding factor } 3 \text { (Double-stranded RNA- } \\
\text { binding protein 76) }\end{array}$ & ILF3 \\
\hline 21 & P05783 & $\begin{array}{l}\text { Keratin, type I cytoskeletal } 18 \text { (Cell proliferation-inducing } \\
\text { gene } 46 \text { protein) (Cytokeratin-18) (CK-18) (Keratin-18) (K18) }\end{array}$ & KRT18 \\
\hline 22 & Q6A162 & Keratin, type I cytoskeletal 40 (Cytokeratin-40) & KRT40 \\
\hline 23 & P43364 & $\begin{array}{c}\text { Melanoma-associated antigen } 11 \text { (Cancer/testis antigen 1.11) } \\
\text { (CT1.11) (MAGE-11 antigen) }\end{array}$ & MAGEA11 \\
\hline
\end{tabular}




\begin{tabular}{|c|c|c|c|}
\hline 24 & Q15555 & $\begin{array}{l}\text { Microtubule-associated protein RP/EB family member } 2 \\
\text { (APC-binding protein EB2) (End-binding protein 2) (EB2) }\end{array}$ & MAPRE2 \\
\hline 25 & Q9UPY8 & $\begin{array}{c}\text { Microtubule-associated protein RP/EB family member } 3 \text { (EB1 } \\
\text { protein family member 3) (EBF3) (End-binding protein 3) } \\
\text { (EB3) (RP3) }\end{array}$ & MAPRE3 \\
\hline 26 & Q5JR59 & $\begin{array}{l}\text { Microtubule-associated tumor suppressor candidate } 2 \text { (Cardiac } \\
\text { zipper protein) }\end{array}$ & MTUS2 \\
\hline 27 & Q9NS69 & $\begin{array}{l}\text { Mitochondrial import receptor subunit TOM22 homolog } \\
\text { (hTom22) (1C9-2) (Translocase of outer membrane } 22 \mathrm{kDa} \\
\text { subunit homolog) }\end{array}$ & TOMM22 \\
\hline 28 & Q99683 & Mitogen-activated protein kinase kinase kinase 5 & MAP3K5 \\
\hline 29 & Q96HT8 & MORF4 family-associated protein 1-like 1 & MRFAP1L1 \\
\hline 30 & Q96CD2 & Phosphopantothenoylcysteine decarboxylase (PPC-DC) & PPCDC \\
\hline 31 & O95758 & $\begin{array}{c}\text { Polypyrimidine tract-binding protein } 3 \text { (Regulator of } \\
\text { differentiation 1) (Rod1) }\end{array}$ & РТВP3 \\
\hline 32 & Q9UI14 & Prenylated Rab acceptor protein 1 (PRA1 family protein 1 ) & RABAC1 \\
\hline 33 & P61289 & $\begin{array}{c}\text { Proteasome activator complex subunit } 3 \text { (11S regulator } \\
\text { complex subunit gamma) }\end{array}$ & PSME3 \\
\hline 34 & Q52LJ0 & Protein FAM98B & FAM98B \\
\hline 35 & Q8IZU0 & Protein FAM9B & FAM9B \\
\hline 36 & Q8IZE3 & $\begin{array}{l}\text { Protein-associating with the carboxyl-terminal domain of ezrin } \\
\text { (Ezrin-binding protein PACE-1) (SCY1-like protein 3) }\end{array}$ & SCYL3 \\
\hline 37 & Q9UJ41 & Rab5 GDP/GTP exchange factor (RAP1) & RABGEF1 \\
\hline 38 & Q96HR9 & $\begin{array}{l}\text { Receptor expression-enhancing protein } 6 \text { (Polyposis locus } \\
\text { protein 1-like 1) }\end{array}$ & REEP6 \\
\hline 39 & P49247 & $\begin{array}{c}\text { Ribose-5-phosphate isomerase (EC 5.3.1.6) } \\
\text { (Phosphoriboisomerase) }\end{array}$ & RPIA \\
\hline 40 & Q9GZL7 & $\begin{array}{l}\text { Ribosome biogenesis protein WDR12 (WD repeat-containing } \\
\text { protein 12) }\end{array}$ & WDR12 \\
\hline 41 & Q8IUH3 & $\begin{array}{l}\text { RNA-binding protein } 45 \text { (Developmentally-regulated RNA- } \\
\text { binding protein 1) (RB-1) (RNA-binding motif protein } 45 \text { ) }\end{array}$ & RBM45 \\
\hline 42 & Q9H0F6 & $\begin{array}{l}\text { Sharpin (Shank-associated RH domain-interacting protein) } \\
\text { (Shank-interacting protein-like 1) (hSIPL1) }\end{array}$ & SHARPIN \\
\hline
\end{tabular}




\begin{tabular}{|c|c|c|c|}
\hline 43 & O43805 & $\begin{array}{l}\text { Sjoegren syndrome nuclear autoantigen } 1 \text { (Nuclear autoantigen } \\
\text { of } 14 \mathrm{kDa})\end{array}$ & SSNA1 \\
\hline 44 & Q01082 & $\begin{array}{l}\text { Spectrin beta chain, non-erythrocytic } 1 \text { (Beta-II spectrin) } \\
\text { (Fodrin beta chain) (Spectrin, non-erythroid beta chain 1) }\end{array}$ & SPTBN1 \\
\hline 45 & P00441 & $\begin{array}{c}\text { Superoxide dismutase [Cu-Zn] (EC 1.15.1.1) (Superoxide } \\
\text { dismutase 1) (hSod1) }\end{array}$ & SOD1 \\
\hline 46 & Q9NVV9 & THAP domain-containing protein 1 & THAP1 \\
\hline 47 & P10599 & $\begin{array}{c}\text { Thioredoxin (Trx) (ATL-derived factor) (ADF) (Surface- } \\
\text { associated sulphydryl protein) (SASP) }\end{array}$ & TXN \\
\hline 48 & Q9H3M7 & $\begin{array}{l}\text { Thioredoxin-interacting protein (Thioredoxin-binding protein } \\
\text { 2) (Vitamin D3 up-regulated protein 1) }\end{array}$ & TXNIP \\
\hline 49 & Q15654 & $\begin{array}{l}\text { Thyroid receptor-interacting protein } 6 \text { (TR-interacting protein } \\
\text { 6) (TRIP-6) (Opa-interacting protein 1) (OIP-1) (Zyxin-related } \\
\text { protein 1) (ZRP-1) }\end{array}$ & TRIP6 \\
\hline 50 & Q96CG3 & $\begin{array}{c}\text { TRAF-interacting protein with FHA domain-containing } \\
\text { protein A }\end{array}$ & TIFA \\
\hline 51 & Q04206 & $\begin{array}{c}\text { Transcription factor p65 (Nuclear factor NF-kappa-B p65 } \\
\text { subunit) (Nuclear factor of kappa light polypeptide gene } \\
\text { enhancer in B-cells 3) }\end{array}$ & RELA \\
\hline 52 & P55072 & Transitional endoplasmic reticulum ATPase (TER ATPase) & VCP \\
\hline 53 & P67936 & Tropomyosin alpha-4 chain (TM30p1) (Tropomyosin-4) & TPM4 \\
\hline 54 & Q6RW13 & $\begin{array}{l}\text { Type-1 angiotensin II receptor-associated protein (AT1 } \\
\text { receptor-associated protein) }\end{array}$ & AGTRAP \\
\hline 55 & P08621 & $\begin{array}{l}\text { U1 small nuclear ribonucleoprotein } 70 \mathrm{kDa} \text { (U1 snRNP } 70 \\
\mathrm{kDa})(\mathrm{U} 1-70 \mathrm{~K})(\mathrm{snRNP} 70)\end{array}$ & SNRNP70 \\
\hline 56 & Q9Y5K5 & $\begin{array}{c}\text { Ubiquitin carboxyl-terminal hydrolase isozyme L5 (UCH-L5) } \\
\text { (EC 3.4.19.12) (Ubiquitin C-terminal hydrolase UCH37) } \\
\text { (Ubiquitin thioesterase L5) }\end{array}$ & UCHL5 \\
\hline 57 & Q8N1B4 & Vacuolar protein sorting-associated protein 52 homolog & VPS52 \\
\hline 58 & P08670 & Vimentin & VIM \\
\hline 59 & O43829 & $\begin{array}{l}\text { Zinc finger and BTB domain-containing protein } 14 \text { (Zinc } \\
\text { finger protein } 161 \text { homolog) }\end{array}$ & ZBTB14 \\
\hline
\end{tabular}


Supplementary Table 2.5. Four cliques in the disease network of Trx 2 that relate ten different diseases.

Diseases in more than one clique are in bold. The numbering of cliques is arbitrary.

$\begin{array}{ccc}\text { Clique 1 } & \begin{array}{c}\text { Gene } \\ \text { name }\end{array} & \begin{array}{c}\text { Uniprot } \\ \text { ID }\end{array} \\ \text { TRIOSEPHOSPHATE ISOMERASE DEFICIENCY } & \text { TPI1 } & \text { P17751 } \\ \text { COMBINED OXIDATIVE PHOSPHORYLATION DEFICIENCY } & \text { TXN2 } & \text { Q99757 } \\ \text { LACTATE DEHYDROGENASE B DEFICIENCY } & \text { LDHB } & \text { Q5M8R7 } \\ \text { PARKINSON'S DISEASE } & \text { PARK7 } & \text { Q99LX0 } \\ \text { Clique 2 } & \\ \text { MITOCHONDRIAL COMPLEX III DEFICIENCY, NUCLEAR TYPE 5 } & \text { UQCRC2 } & \text { Q9DB77 } \\ \text { MITOCHONDRIAL COMPLEX II DEFICIENCY } & \text { SDHA } & \text { Q8K2B3 } \\ \text { COMBINED OXIDATIVE PHOSPHORYLATION DEFICIENCY } & \text { TXN2 } & \text { Q99757 } \\ \text { PYRUVATE DEHYDROGENASE COMPLEX DEFICIENCY } & \text { PDHA1 } & \text { P35486 } \\ \text { Clique 3 } & & \\ \text { ANEMIA, SIDEROBLASTIC } & \text { HSPA9 } & \text { P38647 } \\ \text { COMBINED OXIDATIVE PHOSPHORYLATION DEFICIENCY } & \text { TXN2 } & \text { Q99757 } \\ \text { LACTATE DEHYDROGENASE B DEFICIENCY } & \text { LDHB } & \text { Q5M8R7 } \\ \text { Clique 4 } & & \\ \text { MITOCHONDRIAL COMPLEX II DEFICIENCY } & \text { SDHA } & \text { Q8K2B3 } \\ \text { TRIOSEPHOSPHATE ISOMERASE DEFICIENCY } & \text { TPI1 } & \text { P17751 } \\ \text { LACTATE DEHYDROGENASE B DEFICIENCY } & \text { TXN2 } & \text { Q99757 } \\ \text { COMBINED OXIDATIVE PHOSPHORYLATION DEFICIENCY } & \text { LDHB } & \text { Q5M8R7 }\end{array}$

